\title{
Uma técnica automática baseada em morfologia matemática para medida de sinal em imagens de cDNA Daniel Oliveira Dantas
}

\author{
DISSERTAÇÃO APRESENTADA \\ $\mathrm{AO}$ \\ INSTITUTO DE MATEMÁTICA E ESTATÍSTICA \\ DA \\ UNIVERSIDADE DE SÃO PAULO \\ PARA OBTENÇÃO DO GRAU DE MESTRE \\ $\mathrm{EM}$ \\ CIÊNCIA DA COMPUTAÇÃO
}

Área de Concentração : Ciência da Computação

Orientador : Prof. Dr. Junior Barrera

- São Paulo, janeiro de 2004 - 

aos meus pais Rubem e Eliana e à minha tia Silvia 



\section{Agradecimentos}

Agradeço a Deus por me criar e a Jesus por me salvar. A toda minha família por estar sempre presente. Aos meus professores, colegas e amigos do CCPA, que é muito mais que um colégio, por seu companheirismo na conquista do Vestibular. Aos professores do IME por seu profissionalismo e competência. Aos colegas e amigos do BIOINFO e do Instituto Ludwig, que me apoiaram durante o programa de mestrado.

Em particular,

Aos meus pais Rubem e Eliana, por me darem à luz e pela melhor educação e instrução possível, e à minha tia Silvia, que teve grande influência na minha educação, e que me inspirou a querer estudar na USP.

Aos meus primos e primas, Ana Luiza, Anizio, Carol, Diogo, Fabiane, Fábio, Fernanda, Fernando, Ivana, Iza, Julia, Lucas, Marta Carine, Paula, Thiago etc pela amizade incondicional durante toda minha vida. Aos meus padrinhos Ana Luzia e Rivaldo e a todos os outros tios, tias, e avós pelos bons conselhos e amizade.

Aos amigos e colegas do colégio, Anelar Nunes de Carvalho Filho, Gilberto Monte Lima, Alexandre Dantas Pereira, André Gustavo Andrade Monteiro, Daniel Moura de Figueiredo,

Décio Fragata da Silva, Jefferson Andrade Almeida, Rodolpho Rabelo Pedrosa Costa etc, que me ajudaram a tornar a luta por uma vaga na universidade uma coisa leve e divertida, e que me ensinaram a ver o companheiro não como um concorrente, mas como um membro de uma mesma equipe.

À Universidade de Soka e à CCINT-USP pela oportunidade de realizar meu sonho de fazer um intercâmbio no exerior.

Aos amigos Edward Autoexec Iamamoto, Ailton A. de Oliveira, Cléber da C. Oliveira, Henry K. Oyagawa, Pratip Roy Chowdhury e Silvio R. de Faria Jr., com participação especial de Edson, que me ajudaram a derrotar Masaishi. 
Ao professor Adilson Simonis por todas as oportunidades, e à Luciana Delfini de Campos, que, mais do que uma companheira de trabalho, acabou se tornando uma grande amiga.

Aos membros do BIOINFO, Eduardo Jordão Neves, João Eduardo Ferreira, Marcel Brun, Nina Sumiko Tomita Hirata, Roberto Hirata, Roberto Marcondes Cesar Junior, Nestor Walter Trepode etc, pelas discussões, sugestões e apoio que tornaram possível a realização deste trabalho.

Às pesquisadoras Beatriz Simonsen Stolf e Helena Paula Brentani do Instituto Ludwig, e Maria Aparecida Nagai da FM-USP, pelas imagens que aparecem neste trabalho.

Aos pesquisadores Hernando A. del Portillo do ICB-USP e Luiz Fernando Lima Reis do Institudo Ludwig pelas imagens, sugestões e participação do decorrer do meu mestrado.

Ao pesquisador Gustavo Henrique Esteves pela participação e colaboração direta com imagens, sugestões, dados e idéias que foram de grande valor na elaboração desta dissertação.

E finalmente ao meu professor e orientador Junior Barrera, que há muitos anos me adotou como parte da família BIOINFO, antigo Laboratório de Processamento de Imagens, e que teve papel decisivo na elaboração deste trabalho.

A todos vocês, muito obrigado! 


\section{Resumo}

O objetivo deste trabalho é apresentar uma técnica automática baseada em morfologia matemática para medida de sinal em imagens de $c D N A$ desenvolvida no BIOINFO, em parceria com o Instituto Ludwig de Pesquisa contra o Câncer.

A tecnologia de lâminas de cDNA é um processo baseado em hibridização que possibilita observar a concentração relativa de mRNA de amostras de tecidos analisando a luminosidade de sinais fluorescentes ou radioativos. Hibridização é o processo bioquímico onde duas fitas de ácido nucleico com seqüências complementares se combinam.

A técnica apresentada permite o cálculo da expressão gênica com alto grau de automação, podendo o usuário corrigir com facilidade eventuais erros de segmentação. O usuário interage com o programa apenas para selecionar as imagens e inserir os dados de geometria da lâmina.

A estratégia de solução usada tem três fases: gradeamento dos blocos, gradeamento dos spots e segmentação dos spots. Todas as fases utilizam filtros morfológicos e as fases de gradeamento possuem um passo final de correção baseado nos dados de geometria da lâmina o que aumenta a robustez do processo, que funciona bem mesmo em imagens ruidosas. 



\begin{abstract}
The objective of this work is to present the automated technique for measuring signal from $c D N A$ images developed in BIOINFO, associated with the Ludwig Institute for Cancer Research.

Microarray technology is a hybridization based process that makes possible to quantify the relative abundance of mRNA in two tissue samples analysing the luminosity of fluorescent or radioactive signals. Hybridization is a biochemical process where a strand of nucleic acid matches up its counterpart.

The developed technique permits the calculation of gene expression with a high level of automation. Besides that, the user can easily correct eventual segmentation mistakes. The user interacts with the program only to select the images and to set the slide geometry parameters.

The solution strategy has three main steps: subarray griding, spots gridding and spots detection. All the steps use morphological filters, and the two gridding steps have a final correction substep based on the slide geometry, increasing the process robustness, that works well even in noisy images.
\end{abstract}





\section{Sumário}

1 Introdução $\quad 1$

1.1 Contribuições desta dissertação . . . . . . . . . . . . . . . . 4

1.2 Organização do trabalho . . . . . . . . . . . . . . . . . . 4

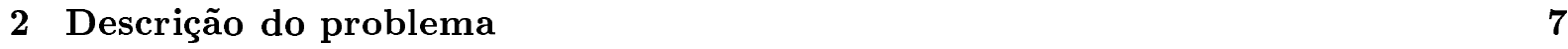

2.1 Expressão gênica . . . . . . . . . . . . . . . . . . . . 7

2.2 Tecnologia de microarrays . . . . . . . . . . . . . . . . . . 10

2.3 Variantes da tecnologia de microarrays . . . . . . . . . . . . . . . 15

2.4 Problema de medida . . . . . . . . . . . . . . . . . . 15

2.5 Soluções disponíveis no mercado . . . . . . . . . . . . . . . 16

2.5 .1 ScanAlyze . . . . . . . . . . . . . . . 16

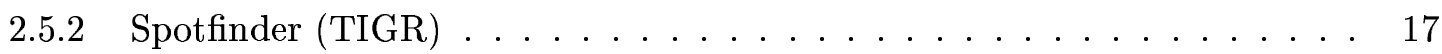

2.5 .3 Arrayvision ............................... 17

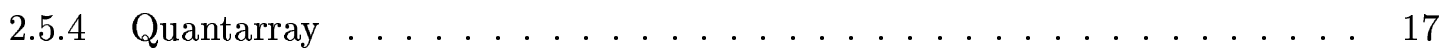

$2.5 .5 \quad \mathrm{UCSF}$ Spot $\ldots \ldots \ldots \ldots \ldots \ldots \ldots \ldots$

3 Segmentação desenvolvida $\quad 19$

3.1 Introdução . . . . . . . . . . . . . . . . . . 19

3.2 Morfologia matemática . . . . . . . . . . . . . . . 19

3.2.1 Paradigma de Beucher-Meyer . . . . . . . . . . . . . . 22

3.3 Gradeamento automático dos blocos . . . . . . . . . . . . . . . 22

3.4 Gradeamento automático dos spots . . . . . . . . . . . . . . 26

3.4 .1 Passo de correção . . . . . . . . . . . . . . . . . . 30

3.5 Segmentação dos spots . . . . . . . . . . . . . . . . 33 
4 Modelos e medida de expressão gênica $\quad 43$

4.1 Introdução . . . . . . . . . . . . . . . . . . . . . . 43

4.2 Modelos de expressão gênica . . . . . . . . . . . . . . . . . 43

4.2 .1 Modelo linear . . . . . . . . . . . . . . . . . . . . . . 43

4.2 .2 Modelo de ruído aditivo . . . . . . . . . . . . . . . . . . . 44

4.2 .3 Modelo de ruído exponencial . . . . . . . . . . . . . . . . 44

4.3 Medida da expressão gênica . . . . . . . . . . . . . . . 46

4.3 .1 Histograma . . . . . . . . . . . . . . . 47

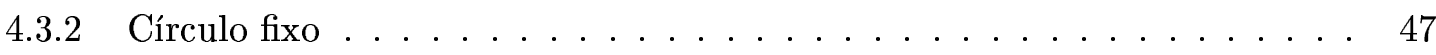

4.3 .3 Adaptativo . . . . . . . . . . . . . . . . . . 48

4.3 .4 Regressão . . . . . . . . . . . . . . . . . . . . 49

4.3.5 Segmentação morfológica . . . . . . . . . . . . . . . . 49

4.4 Correção do background . . . . . . . . . . . . . . . . . . . . . 49

4.5 Influência do background no sinal . . . . . . . . . . . . . . . . . 50

5 O software desenvolvido $\quad 53$

5.1 Introdução . . . . . . . . . . . . . . . . . . . 53

5.2 Interface com o usuário $\ldots \ldots \ldots \ldots \ldots \ldots \ldots \ldots$

$5.2 .1 \quad$ Interface principal $\ldots \ldots \ldots \ldots \ldots \ldots$

$5.2 .2 \quad$ Interface de parâmetros específicos . . . . . . . . . . . . . 57

$5.2 .3 \quad$ Interface de parâmetros globais . . . . . . . . . . . . . . 59

5.2 .4 Interface de análise do bloco f . . . . . . . . . . . . . . 61

5.2 .5 Correção de rotação . . . . . . . . . . . . . . . . 62

5.3 Arquivo de saída . . . . . . . . . . . . . . . . 64

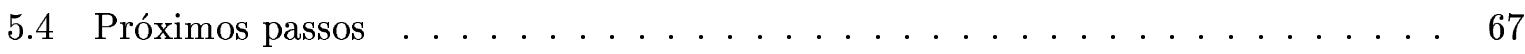

$\begin{array}{llr}6 & \text { Validação } & 69\end{array}$

$\begin{array}{lll}7 & \text { Conclusão } & 83\end{array}$

$\begin{array}{ll}\text { A Publicações associadas a esta dissertação } & \mathbf{8 5}\end{array}$

B Normalização $\quad \mathbf{8 7}$

B.1 Introdução. . . . . . . . . . . . . . . . . . . . 87 
B.2 Normalização intralâmina . . . . . . . . . . . . . . . . 88

B.2.1 Normalização global . . . . . . . . . . . . . . . . . . . 88

B.2.2 Normalização por genes de housekeeping . . . . . . . . . . . . . . 88

B.2.3 Normalização segundo a intensidade . . . . . . . . . . . . . . . . . 88

B.3 Normalização por swap . . . . . . . . . . . . . . . . . . . 89 



\section{Lista de Figuras}

2.1 Expressão gênica: i - Transcrição, ii - Tradução. . . . . . . . . . . . . . . . . 9

2.2 Tecnologia de microarray $[1] \ldots \ldots \ldots \ldots \ldots \ldots \ldots$

2.3 Exemplo de imagem de microarray digitalizada a laser (GHE037, produzida com genes sintéticos pelo pesquisador Gustavo Henrique Esteves, do Instituto Ludwig). 12

2.4 Exemplo de imagem de microarray. . . . . . . . . . . . . . . . . . . 13

2.5 Exemplo de segmentação de blocos de microarray (lâmina produzida pela pesquisadora Beatriz Simonsen Stolf, do Instituto Ludwig). . . . . . . . . . . . . . . 14

3.1 Exemplo de perfil vertical. . . . . . . . . . . . . . . . . 23

3.2 Resultado do primeiro filtro. . . . . . . . . . . . . . . . . . 24

3.3 Resultado do segundo filtro. . . . . . . . . . . . . . . . 25

3.4 Fronteiras dos blocos. . . . . . . . . . . . . . . . . 26

3.5 Correção da segmentação morfológica. . . . . . . . . . . . . . . . . 27

3.6 Gradeamento horizontal. . . . . . . . . . . . . . . . . . . . 28

3.7 Gradeamento vertical. . . . . . . . . . . . . . . . . . . 28

3.8 Primeiro bloco do microarray da Fig. 2.4. . . . . . . . . . . . . . . . 29

3.9 Composição das linhas de grade com o bloco da Fig. 3.8. . . . . . . . . . . . . . 29

3.10 (a) Gradeamento morfológico do bloco 6 da lâmina da Figura 2.5. (b) Apagando linhas da grade. (c) Adicionando linhas à grade. . . . . . . . . . . . . . . 36

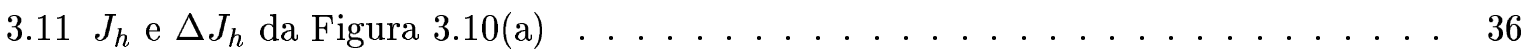

3.12 Gráfico da função de custo para $d_{z}=10$ e $t \in[1,100] \ldots \ldots \ldots \ldots$

3.13 (a) Gradeamento morfológico do bloco 4 (linha 1, coluna 4) da lâmina da Figura 2.5. (b) Correção final. . . . . . . . . . . . . . . . . . . 37

3.14 (a) Gradeamento morfológico do bloco 11 (linha 3, coluna 3) da lâmina da Figura 2.5. (b) Correção final. . . . . . . . . . . . . . . . . . 38

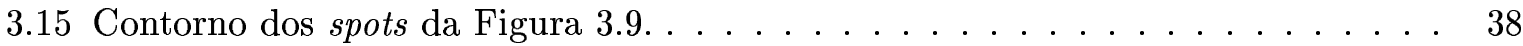


3.16 Exemplo de segmentação de spots de lâmina de oligonucleotídeos (mos13-083 extraída da página http://derisilab.ucsf.edu/falciparum/) . . . . . . . 39

3.17 Exemplo de gradeamento de membrana (lâmina produzida pela pesquisadora Maria Aparecida Nagai, Departamento de Radiologia, FM-USP). . . . . . . . . . . 40

3.18 Segmentação do primeiro bloco da Figura $3.17 \ldots \ldots$. . . . . . . . . . 40

3.19 Exemplo de gradeamento de lâmina de cDNA de experimento de câncer digitalizada a laser (lâmina produzida pela pesquisadora Helena Paula Brentani, Instituto Ludwig). . . . . . . . . . . . . . . . . . . . . . 41

3.20 Segmentação do primeiro bloco da Figura 3.19 . . . . . . . . . . . . . . . 41

3.21 Segmentação do primeiro bloco da lâmina de genes sintéticos da Figura 2.3 . . 42

3.22 Segmentação do bloco da Figura $3.13 \ldots \ldots$. . . . . . . . . . . . . 42

4.1 Diferentes formas de segmentação do background. A região delimitada pelo círculo mais interno representa o sinal. As outras regiões representam as diferentes formas de delimitar o background: os outros dois círculos em linha cheia são usados pelo Quantarray, o quadrado pontilhado pelo ScanAlyze, e os quatro quadrados tracejados pelo CSIRO Spot $[2] \ldots \ldots \ldots \ldots \ldots \ldots$. . . . . . . . 48

5.1 Interface principal do programa com a segmentação dos blocos terminada. . . . . 55

5.2 Interface de parâmetros específicos da lâmina. . . . . . . . . . . . . 58

5.3 Interface de parâmetros globais da família de experimentos. . . . . . . . . . . 60

5.4 Interface para análise de blocos individuais. . . . . . . . . . . . . . 62

5.5 O usuário seleciona dois pontos para definir o ângulo de rotação. . . . . . . . . 63

6.1 Erros cometidos no experimento exp1/1 (com diluição 5). . . . . . . . . . . . 72

6.2 Erros cometidos no experimento $\exp 1 / 1 \ldots \ldots \ldots \ldots \ldots \ldots$. . . . . . . 72

6.3 Erros cometidos nos experimentos $\exp 3 / 1$ e $\exp 6 / 1 \ldots \ldots \ldots$

6.4 Erros cometidos nos experimentos exp1/1-5/1, exp1/1-2/1 e exp1/1-10/1. . . . 74 


\section{Lista de Tabelas}

6.1 Dados obtidos para o experimento exp1/1 (diluição cinco) . . . . . . . . . . . 75

6.2 Dados obtidos para o experimento exp1/1. . . . . . . . . . 76

6.3 Dados obtidos para o experimento exp3/1. . . . . . . . . . . 77

6.4 Dados obtidos para o experimento exp6/1. . . . . . . . . . . . 78

6.5 Dados obtidos para o experimento exp1/1-5/1. . . . . . . . . . . 79

6.6 Dados obtidos para o experimento exp1/1-2/1. . . . . . . . . . . . 80

6.7 Dados obtidos para o experimento exp1/1-10/1 . . . . . . . . . . . 81 



\section{Capítulo 1}

\section{Introdução}

O objetivo da tecnologia de lâminas de cDNA é medir o nível de expressão dos genes. Baseia-se no fato de que quando um fragmento de RNA encontra outro de cDNA com seqüência complementar, ambos tendem a se unir. Um experimento é feito em três etapas: primeiro fragmentos de cDNA de diversos genes são dispostos sobre algum substrato, cada gene em um pequeno círculo; a segunda etapa consiste em extrair RNA dos tecidos a serem analisados e marcá-lo com corantes fluorescentes. Finalmente a lâmina é mergulhada na sopa de RNA, cujos framentos se ligarão ao substrato nas regiões que contêm o cDNA correspondente. Quanto mais RNA de um certo gene na sopa, mais os pontos com genes correspondentes fluorescerá. Devido à dificuldade de se obter os níveis absolutos de expressão [3], os experimentos costumam ser feitos usando-se duas amostras de RNA, e o que se calcula são suas expressões relativas.

Existem diversos tipos de substrato, corantes e técnicas de extração de RNA. A síntese de cDNA pode ser feita por transcrição reversa ou pela tecnologia Affymetrix $®$ GeneChipß $[4,5]$. Nesse trabalho, ao nos referirmos a lâminas de cDNA com genes impressos em pequenos círculos dispostos de forma matricial, usaremos a palavra microarray.

Para analisar computacionalmente o experimento bioquímico, a lâmina de microarray é digitalizada por um scanner de alta resolução gerando uma imagem para cada canal. Cada pixel da imagem é a média do sinal luminoso emitido por moléculas marcadas com corante que aderiram à lâmina numa determinada área. A esse valor são adicionados ruídos estocásticos provenien- 
tes, tanto do experimento bioquímico, quanto do procedimento de digitalização, amplificação eletrônica etc. Nas câmaras que funcionam com luz não polarizada, pontos com alta intensidade influenciam pontos vizinhos causando um espalhamento do sinal e gerando imagens sem muito contraste.

Além do ruído, outra dificuldade encontrada é que as moléculas da amostra, os targets, numa proporção pequena mas não desprezível, aderem à lâmina sem encontrar moléculas de seqüência complementar, os probes correspondentes (seguindo a definição probe e target adotada no suplemento da Nature Genetics [6]), e até mesmo no próprio substrato. Normalmente se subtrai a intensidade encontrada nas regiões sem probe, o chamado background, da intensidade do sinal como forma de eliminar a hibridização não específica [2], ou seja, a contribuição que não é devida à hibridização do mRNA da amostra com o DNA da lâmina. No entanto experimentos com controles negativos mostram spots com intensidade inferior ao background, dando evidências de que a hibridização não específica não deveria ser medida pelo valor do background, e sim pelo valor dos controles negativos [7].

As moléculas marcadas tendem a hibridizar com as moléculas da lâmina com seqüência complementar, assim, os spots da lâmina que contêm genes mais expressos na amostra marcada com o corante cy3 devem aparecer na imagem como círculos verdes intensos; caso contenham genes mais expressos na amostra com cy5, parecerão vermelhos; se a expressão for a mesma, devem parecer amarelos.

Para fazer a medida, analisa-se a imagem da lâmina usando algum software que separe o sinal, no interior dos spots, do ruído fora dos mesmos, chamado background. Separados os pixels do sinal, estima-se, para cada spot, a razão entre seus dois canais. Além disso, o software deve ser capaz de identificar qual a posição do spot no respectivo subarray ou bloco, e a posição do bloco na lâmina por meio de índices que relacionem o spot com os dados de uma tabela de genes usados no experimento.

A tarefa de segmentação de imagens de microarray envolve vários problemas que dificultam sua automatização. As imagens são ruidosas, os spots e subarrays, também chamados blocos, são espaçados irregularmente e os spots apresentam formas de crescente e de rosca, além do formato esperado, aproximadamente circular. 
Cada software apresenta uma abordagem do problema, mas muitas vezes o usuário precisa interagir com a imagem por algumas horas até obter uma segmentação de qualidade que gere bons dados. Geralmente o usuário escolhe alguns spots nos extremos da imagem e o software os interpola assumindo que os demais blocos e spots são uniformemente distribuídos. Porém, a distribuição dos spots quase nunca é perfeitamente regular, e, para obter bons dados de expressão, o usuário deve ajustar a grade manualmente para os spots desalinhados.

Alguns programas podem opcionalmente ajustar a grade para spots desalinhados, tentando encontrar uma posição melhor, próxima à encontrada pela interpolação. Mas isso geralmente não funciona e é facilmente afetado pelo ruído.

Além disso, os programas que assumem que spots têm o formato perfeitamente circular podem gerar dados de má qualidade, já que, nesses casos, serão identificados pixels do background como sendo parte do sinal.

O objetivo do nosso trabalho é automatizar tal tarefa, tornando os dados de segmentação reprodutíveis, uma vez que, na segmentação manual, mesmo que o operador do software e a imagem sejam os mesmos, o resultado de duas segmentações deverá ser diferente. Além disso, queremos garantir a precisão dos resultados, encontrando corretamente a posição dos spots sem que haja a necessidade de interferência do usuário. Um método totalmente automático também economiza mão-de-obra e oferece maior rapidez no processamento das imagens.

Dividimos a segmentação em: gradeamento dos blocos, gradeamento dos spots e segmentação dos spots.

O gradeamento dos blocos e dos spots é importante para fazer o chamado endereçamento, que é associar a cada spot um índice, para que se saiba qual gene foi nele colocado, e sua expressão, que é calculada no final do processo.

Para realizar todo o processo, a informação necessária são nove valores numéricos referentes à geometria da lâmina: o número de linhas de blocos, número de colunas de blocos, distância horizontal entre blocos, distância vertical entre blocos, número de linhas e colunas de spots por bloco, distância vertical e horizontal entre os centros dos spots, e diâmetro do spot. 


\subsection{Contribuições desta dissertação}

O objetivo da ferramenta proposta nesse trabalho é gerar a saída de forma automática como o UCSF Spot, permitindo, porém, que o usuário corrija com facilidade eventuais erros de segmentação. Recebe como entrada os dados da geometria da lâmina, ou seja, número de blocos, de spots em cada bloco na vertical e na horizontal, respectivas distâncias e diâmetro do spot.

Como o processo é completamente automático, a saída sempre será a mesma, independente do usuário.

Recentemente, um método similar ao nosso desenvolvido independentemente foi publicado na Bioinformatics [8]. Sua técnica de segmentação dos blocos é um pouco diferente da nossa: enquanto analisamos os perfis horizontal e vertical, sua abordagem analisa a própria imagem reduzida em algumas vezes. Ambas as técnicas usam watershed para segmentar os spots.

\subsection{Organização do trabalho}

Neste primeiro capítulo foram apresentados os objetivos do trabalho, assim como as motivações para a criação de um método completamente automático de segmentação de imagens de cDNA. No Capítulo 2 serão apresentados os fundamentos da expressão gênica e como a tecnologia de microarrays é usada para medi-la. Também são apresentadas de forma sucinta algumas das soluções disponíveis no mercado. No Capítulo 3 é apresentado em detalhes o algoritmo de segmentação desenvolvido, bem como uma introdução à morfologia matemática, necessária para o seu entendimento. No Capítulo 4, modelos de expressão que mostram a relação entre seu valor real e o valor observado na lâmina são apresentados. Também são mostrados os métodos de estimação do sinal mais usados e a influência do background no sinal é discutida. No Capítulo 5 há uma descrição detalhada do programa desenvolvido, sua interface com o usuário, dados de entrada e o formato do arquivo de saída. No Capítulo 6 são comparados os diversos métodos de estimação do sinal apresentados previamente e os respectivos erros são medidos, mostrando que o programa desenvolvido se comporta da forma esperada. As conclusões e comentários finais são apresentados no Capítulo 7 . 
No Apêndice A há uma listagem das publicações associadas a esta dissertação. No Apêndice B são descritas algumas técnicas de normalização, que devem ser aplicadas aos dados de saída antes de continuar a sua análise. 


\section{Capítulo 2}

\section{Descrição do problema}

\subsection{Expressão gênica}

Genes são importantes para transferir, de pai para filho, ou, dentro de um mesmo organismo, às células resultantes de uma divisão celular, as informações necessárias para regular a atividade metabólica das células. São seqüências ordenadas de nucleotídeos agrupadas em estruturas autoreplicáveis de ácido desoxirribonucléico (DNA) nos núcleos das células eucariotas, denominadas cromossomos.

A molécula de DNA localizada no núcleo das células normalmente se encontra enrolada sobre si mesma, desenrolando-se somente durante a divisão celular, ou em alguns trechos para a síntese das moléculas de ácido ribonucléico (RNA) que irão para o citoplasma. É formada por uma hélice dupla de DNA que se mantém unida através de pontes de hidrogênio entre suas bases nitrogenadas.

Nucleotídeos são a unidade fundamental dos cromossomos e das moléculas de RNA, sendo compostos por uma base nitrogenada, uma molécula de fosfato e uma molécula de açúcar. As bases nitrogenadas encontradas no DNA são a adenina, guanina, citosina e timina, e no RNA são a adenina, guanina, citosina e uracila. A molécula de açúcar do DNA é a desoxirribose e a do RNA é a ribose.

Como a guanina se liga apenas à citosina e a adenina, apenas à timina ou uracila, pode-se 
deduzir a seqüência original a partir de uma cópia.

Expressão gênica é o processo que envolve a conversão da informação contida nos genes em proteínas. Esse processo ocorre em dois passos (Figura 2.1): i - transcrição da informação codificada em um gene, mediante a síntese de moléculas de RNA mensageiro (mRNA), isto é, cópias do gene que são enviadas para fora do núcleo da célula, e ii - tradução da informação codificada nos nucleotídeos do mRNA mediante a síntese de uma proteína; cada seqüência de mRNA define uma única proteína.

Saber os níveis de transcrição em vários tecidos é importante para responder perguntas como qual o papel de diferentes genes e em que processos atuam; como os genes e seus produtos interagem; como variam os níveis de expressão gênica em vários tipos de células e estados, ou com doenças e tratamentos. Apesar do mRNA não ser o último produto de um gene, transcrição é o primeiro passo da expressão, e informação sobre os níveis de transcrição é necessária para entender as redes de regulação gênica [9].

No caso da síntese de RNA ribossomal (rRNA), encontrado nos ribossomos, e RNA transportador (tRNA), que se liga a aminoácidos e participa da síntese de proteínas, apenas a transcrição é necessária.

Proteínas são macromoléculas compostas por uma ou mais cadeias de aminoácidos em uma certa ordem, dada pela seqüência de bases nitrogenadas do gene que a codifica. Proteínas sao necessárias para a estrutura, funcionamento e regulação das células, tecidos e órgãos. A quantidade de cada proteína constitui uma parte importante do funcionamento interno das células e dos tecidos já que muitas reações ocorrem através delas. Cada proteína tem uma única função. Exemplos de proteínas são as enzimas, hormônios e anticorpos. 


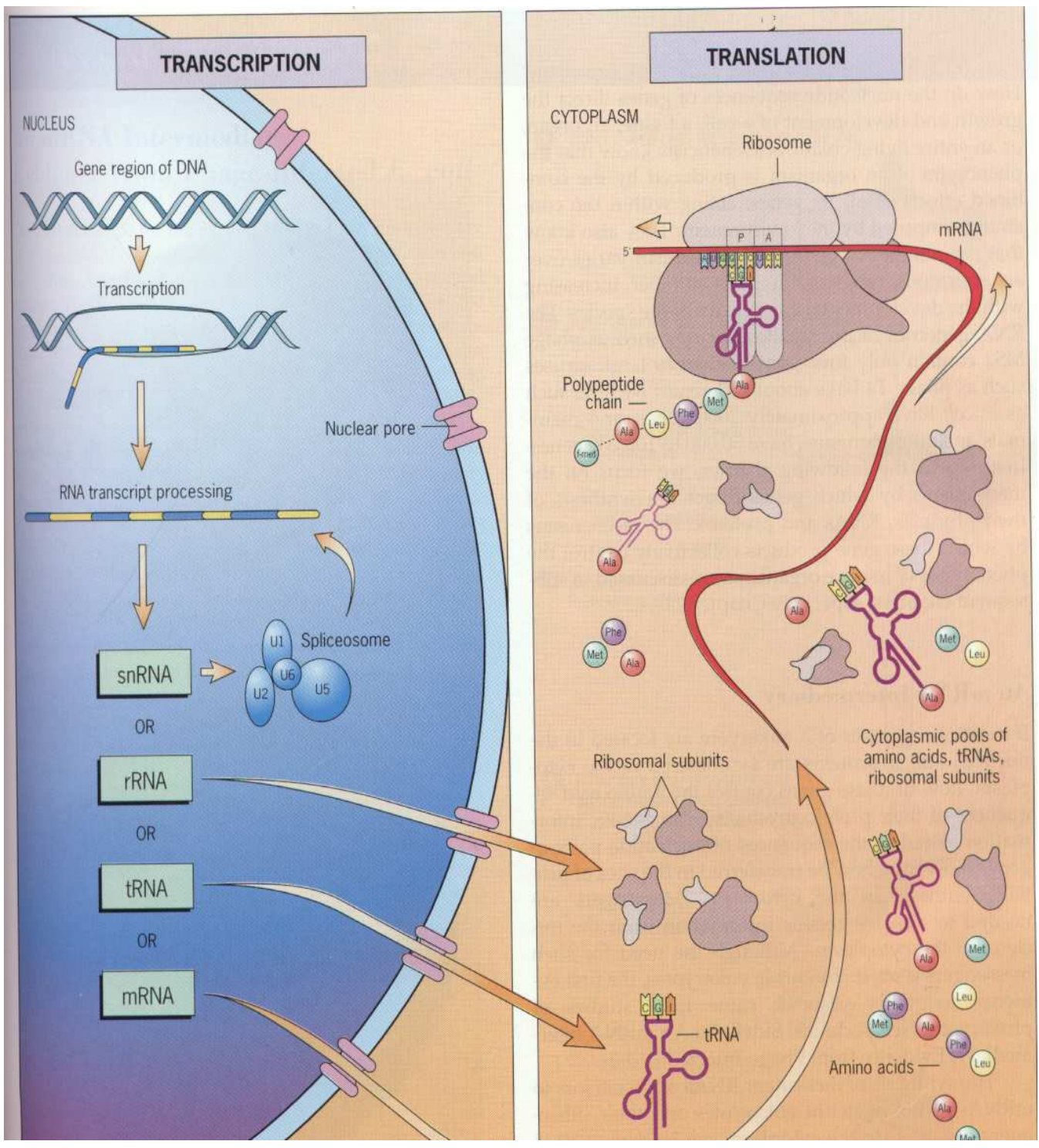

Figura 2.1: Expressão gênica: i - Transcrição, ii - Tradução.

Ref: Biology Pages 
Podemos medir o nível de expressão de cada gene medindo quantas cópias de mRNA estão presentes na célula. Dentre as técnicas mais usadas de medida dos níveis de mRNA estão [10]:

- Microarrays de cDNA

- Chips de oligonucleotídeos Affymetrixß GeneChipß

- RT-PCR (Reverse Transcriptase Polymerase Chain Reaction)

- Análise Serial da Expressão Gênica (SAGE: Serial Analysis of Gene Expression)

\subsection{Tecnologia de microarrays}

A tecnologia de microarrays é um processo baseado em hibridização que possibilita observar a concentração de mRNA de uma amostra de células analisando a luminosidade de sinais fluorescentes. Hibridização é o processo bioquímico onde duas fitas de ácido nucleico com seqüências complementares se combinam.

Uma lâmina de microarray tem, em cada spot, pedaços de cDNA de um gene que se quer estudar. Uma única lâmina pode conter milhares de spots, permitindo que se analisem milhares de genes ao mesmo tempo. Essa lâmina de vidro é mergulhada em uma solução com mRNA extraído da amostra de células, rotulado com corante fluorescente.

Normalmente os experimentos de microarray são feitos com duas amostras de mRNA, cada uma rotulada com um corante fluorescente diferente, em geral cy3 e cy5. Assim, o mRNA hibridiza com o cDNA correspontende, fazendo com que o spot acenda mais na cor correspondente à amostra que contém mais mRNA proveniente do seu gene.

Após esse processo a lâmina é digitalizada em alta resolução gerando uma imagem que deve ser analisada em vários passos. Primeiro se faz o endereçamento, que é associar a cada spot o gene correspondente. Em seguida, deve-se localizar exatamente a região que corresponde ao sinal do spot, a chamada segmentação do spot. Por fim estimar o valor do sinal luminoso de cada spot. Em experimentos com duas amostras de mRNA é medida a expressão relativa do gene nas duas amostras, valor proporcional à intensidade relativa dos dois corantes em cada spot. 

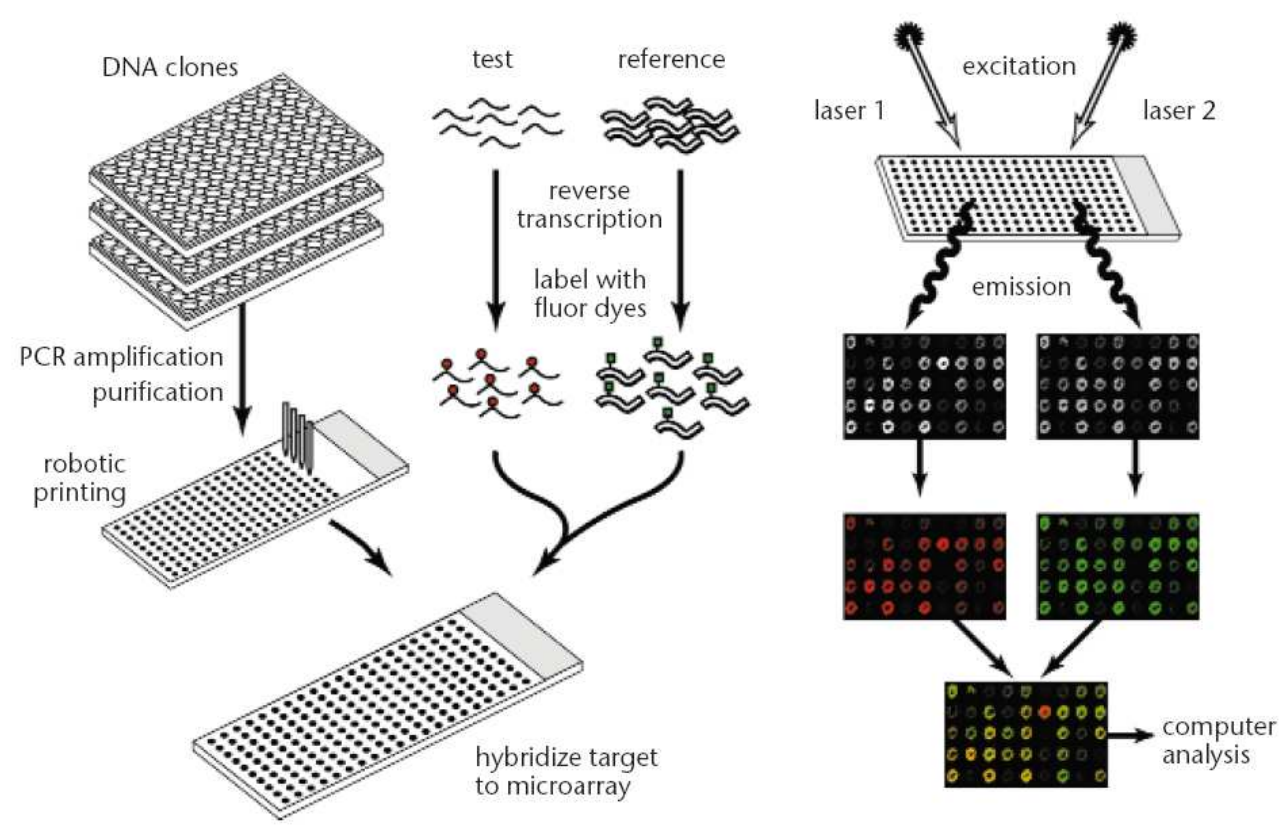

Figura 2.2: Tecnologia de microarray [1].

A região útil, que contém spots, de uma lâmina de microarray típica possui dimensões em torno de $2 \mathrm{x} 4 \mathrm{~cm}$. Tal lâmina, se digitalizada a laser com uma resolução de $10 \mu \mathrm{m}$ por pixel, terá 2000x4000 pixels. Uma boa digitalização deve ter mais de 256 tons de cinza, assim, costuma-se digitalizar para $65536\left(2^{16}\right)$ tons de cinza, onde cada pixel ocupa dois bytes de informação. Se tal lâmina for hibridizada com dois corantes, deve ser digitalizada para uma imagem com dois canais. Essa imagem ocupará cerca de 32 megabytes de informação.

As Figuras 2.3 e 2.4 são exemplos de imagens digitais de lâminas de microarray. A Figura 2.5 mostra o resultado do gradeamento dos blocos.

A tecnologia de microarrays visa analisar a expressão gênica de milhares de genes simultaneamente, objetivando alto throughput. No entanto, encontra um gargalo na fase de segmentação da imagem da lâmina para geração dos dados de expressão gênica. Analisamos diversos programas de análise de imagens de microarray e todos exigem um penoso processo manual, são intensamente interativos. Na Seção 2.5 descrevemos algumas das ferramentas mais populares. 


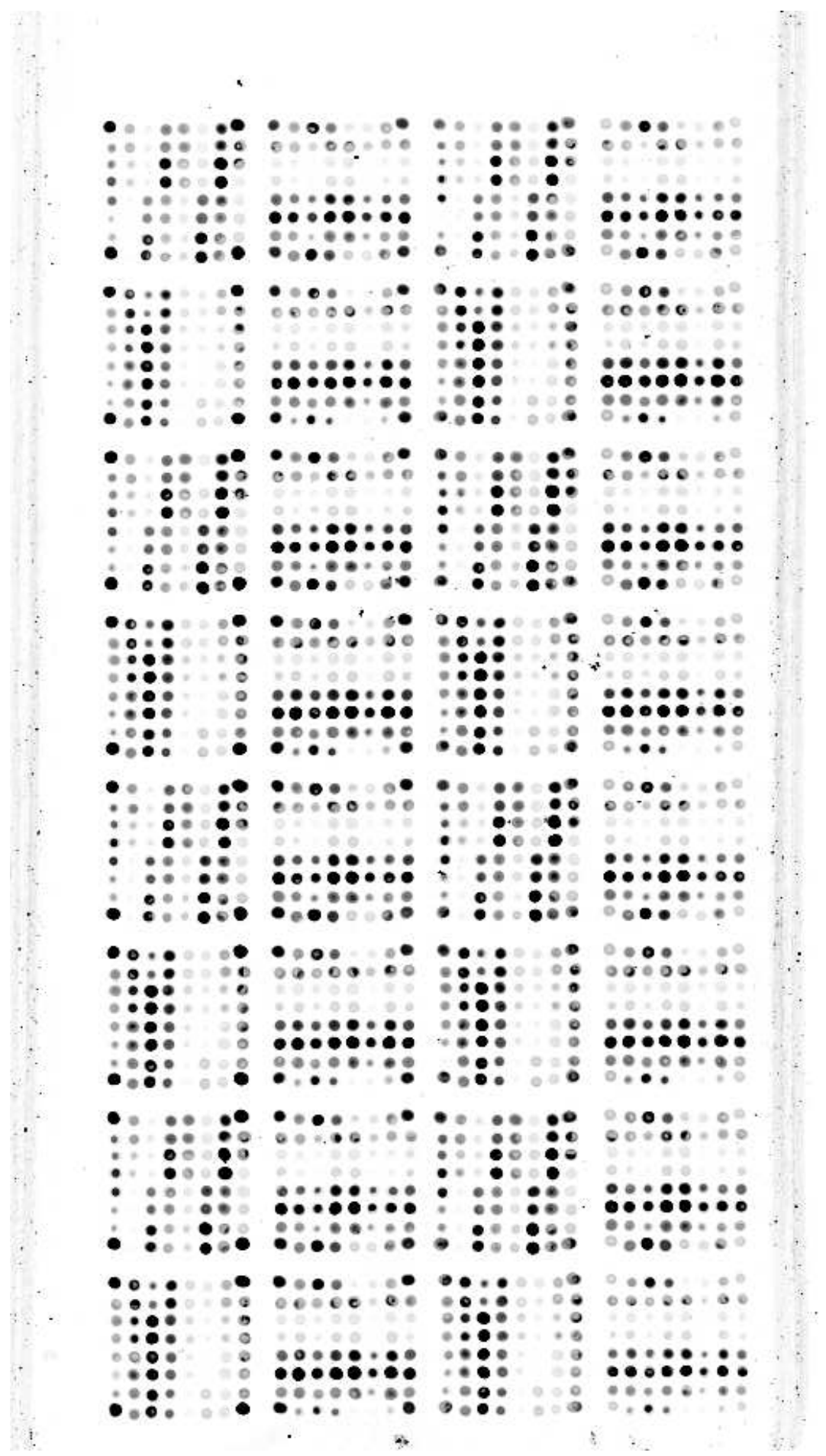

Figura 2.3: Exemplo de imagem de microarray digitalizada a laser (GHE037, produzida com genes sintéticos pelo pesquisador Gustavo Henrique Esteves, do Instituto Ludwig). 


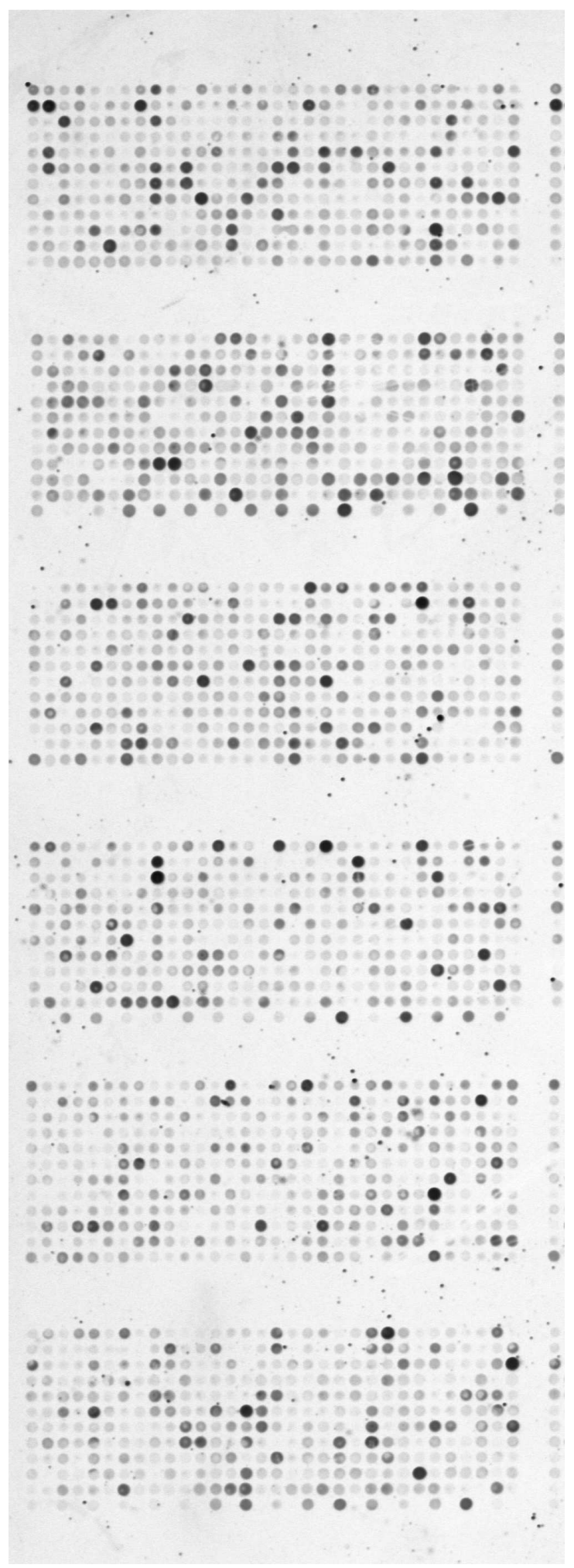

Figura 2.4: Exemplo de imagem de microarray. 


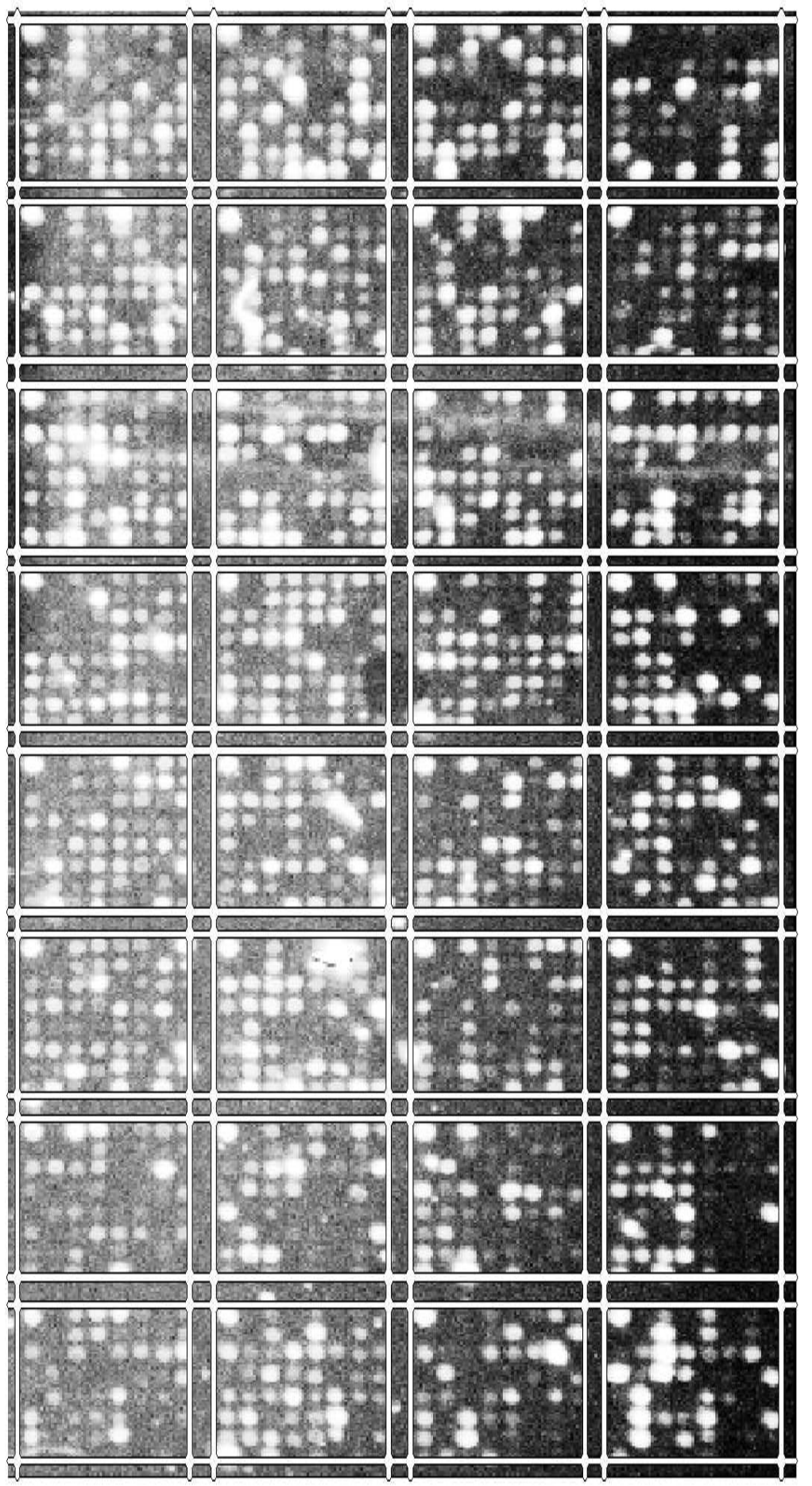

Figura 2.5: Exemplo de segmentação de blocos de microarray (lâmina produzida pela pesquisadora Beatriz Simonsen Stolf, do Instituto Ludwig). 
A técnica desenvolvida elimina tal gargalo, gerando, com mínima interação com o usuário, os dados de expressão gênica.

\subsection{Variantes da tecnologia de microarrays}

A tecnologia de microarray tem algumas variantes que, para efeito de análise de imagens, são equivalentes. Uma delas é a lâmina de oligonucleotídeos [11], que usa probes sintetizados e posteriormente depositados na lâmina. O uso de oligonucleotídeos muito curtos resulta em hibridizações menos específicas e menor sensibilidade, assim oligonucleotídeos mais longos (50100 bases) são usados. Oferecem a vantagem de que a informação sobre seqüencia é suficiente para sintetizar os probes, evitando o manuseio de cDNA [12].

Outra tecnologia é a lâmina de nylon, em geral usada com detecção radioativa, ou seja, os targets são marcados radioativamente. Essas lâminas permitem a análise de apenas uma amostra de cada vez. Os chamados macroarrays são similares, usam o mesmo substrato e marcação, diferindo apenas na escala. Tais lâminas têm em média 10 centímetros de lado [13].

\subsection{Problema de medida}

A partir a imagem, precisa-se extrair uma tabela com o valor de expressão gênica de cada spot. Os dados dessa tabela, se cruzados com os nomes dos respectivos genes, indicam quais genes são mais ou menos expressos na célula sob a condição do experimento, e podem ser usados para responder às perguntas apresentadas na seção 2.1 .

A intensidade do sinal fluorescente em cada spot guarda uma relação linear com a concentração de mRNA na amostra num intervalo de pelo menos cinco ordens de grandeza de diluições [3]. Assim, assumimos que a intensidade da fluorescência $(Y)$ no interior de cada spot deve ser

$$
Y_{i k}=a_{i}+b_{i} X_{i k}
$$

onde $i=1,2$ denota os canais; $k=1, \ldots, K$, os genes; $a$, a intensidade no background; $X_{i k}$ é a intensidade do gene $k$ no canal $i$; e $b_{i}$ é o fator de ganho do fluorcromo usado no canal $i$ [14]. 
Devido a diferenças físicas dos corantes e à configuração do scanner, os valores de $a_{i}$ e $b_{i}$ são diferentes nos dois canais. Neste modelo, as variações de $a_{i}$ e $b_{i}$ dentro de um mesmo canal são ignoradas.

Deve-se observar ainda que a relação acima, em dados reais de microarray sofre influência de ruídos estocásticos de diversas fontes, como amplificação eletrônica na fase da digitalização, hibridização não específica etc.

Na fronteira do spot, o sinal passa a não obedecer a função linear e o sinal cai até se confundir com o background. Assim, a fase de segmentação deve identificar tais pixels como não sendo parte do sinal, ou o resultado será de baixa qualidade.

\subsection{Soluções disponíveis no mercado}

Esta Seção descreve de forma sucinta as principais características, como facilidade de uso, técnicas de segmentação e de cálculo do sinal, das soluções mais populares do mercado.

\subsubsection{ScanAlyze}

Software elaborado pelo Eisen $L a b^{1}$ da Universidade da Califórnia em Berkeley. A licença é gratuita para uso não comercial.

Requer que o usuário identifique alguns spots e encontra os demais por interpolação. Tem uma função para encontrar spots desalinhados, mas não funciona bem. A segmentação dos spots é sempre circular ou elíptica, o que na realidade nem sempre ocorre, ou seja, o círculo identifica como sinal uma região de background, diminuindo a qualidade dos valores de expressão encontrados, o que aumenta a dispersão.

\footnotetext{
${ }^{1}$ rana.lbl.gov/EisenSoftware.htm
} 


\subsubsection{Spotfinder (TIGR)}

Solução criada por The Institute for Genomic Research ${ }^{2}$, sua licença também é gratuita para uso não comercial.

A segmentação dos blocos é feita manualmente, mas a segmentação do sinal dos spots é automática e parametrizada. O usuário escolhe um valor de raio e a área do sinal muda proporcionalmente. Além disso, identifica bem a área do sinal do spot mesmo quando tem forma de meia lua ou de rosca.

\subsubsection{Arrayvision}

Solução comercial da Imaging Research Inc $^{3}$.

Esta ferramenta oferece muitas opções de uso, o que pode confundir o usuário iniciante, mas por outro lado, é uma vantagem para quem já está habituado com o software. É capaz de encontrar spots mal alinhados.

\subsubsection{Quantarray}

Solução da Packard Bioscience ${ }^{4}$. Pode analisar imagens com até cinco cores. Oferece três formas de calcular a expressão: método do histograma, círculo fixo e adaptativo.

\subsubsection{UCSF Spot}

O UCSF Spot é um projeto do Jain $L a b^{5}$, da Universidade da Califórnia em São Francisco.

Sua intenção é fazer todo o processo de segmentação e geração dos dados de forma automática. No entanto, quando a imagem é ruidosa, o resultado pode sair errado e a correção manual é bastante trabalhosa.

\footnotetext{
${ }^{2}$ www.tigr.org/software

${ }^{3}$ www.imagingresearch.com

${ }^{4}$ www.packardbioscience.com

${ }^{5}$ jainlab.ucsf.edu/Projects.html
} 


\section{Capítulo 3}

\section{Segmentação desenvolvida}

\subsection{Introdução}

Neste Capítulo daremos algumas definições necessárias para o entendimento de nossa abordagem dos problemas de gradeamento dos subarrays, gradeamento dos spots e detecção dos spots, que será descrita em detalhes em seguida. As definições foram extraídas de [15] e de [16].

\subsection{Morfologia matemática}

Seja $\mathbf{Z}$ o conjunto dos números inteiros; a origem de $\mathbf{Z}^{2}$ é denotada por $o=(0,0)$. Seja $E$ um retângulo finito e não vazio em $\mathbf{Z}^{2}$, e $K$ um intervalo $[0, k]$ de $\mathbf{Z}$, com $k>0$.

Uma função $f$ de $E$ em $K, f \in K^{E}$, representa uma imagem em tons de cinza, doravante denominada apenas imagem. Cada ponto de $E$ representa um pixel ou ponto da imagem, ou seja, $p \in E$ é um ponto da imagem $f$, cujo tom de cinza vale $f(p)$.

Um subconjunto $B$ de $E$ também é chamado elemento estruturante.

O operador identidade é denotado por $\iota$, e é tal que $\iota(f)=f$.

A união de duas imagens $f_{1}$ e $f_{2}$, denotada $f_{1} \vee f_{2}$, é a função em $K^{E}$ dada por, para todo $x \in E,\left(f_{1} \vee f_{2}\right)(x)=\max \left\{f_{1}(x), f_{2}(x)\right\}$. 
A interseção de duas imagens $f_{1}$ e $f_{2}$, denotada $f_{1} \wedge f_{2}$, é a função em $K^{E}$ dada por, para todo $x \in E,\left(f_{1} \wedge f_{2}\right)(x)=\min \left\{f_{1}(x), f_{2}(x)\right\}$.

A adição de duas imagens $f_{1}$ e $f_{2}$, denotada $f_{1}+f_{2}$, é a função em $K^{E}$ dada por, para todo $x \in E$,

$$
\left(f_{1}+f_{2}\right)(x)= \begin{cases}f_{1}(x)+f_{2}(x) & \text { se } f_{1}(x)+f_{2}(x) \leq k \\ k & \text { caso contrário }\end{cases}
$$

A reflexão de um subconjunto $X \subseteq E$ é o subconjunto $\check{X}=\{r \in E: r=-x, x \in X\}$.

Para todo $X \subseteq E$ e $y \in E, X_{y}$ denota $X$ transladado de $y$, ou seja, $X_{y}=\{x \in E: x-y \in X\}$.

A dilatação e erosão de uma imagem $f$ por um elemento estruturante $B$ são, respectivamente, as funções $\delta_{B}(f)$ e $\varepsilon_{B}(f)$ em $K^{E}$ dadas por, para todo $x \in E$,

$$
\delta_{B}(f)=\max \left\{f(y): y \in \check{B}_{x} \cap E\right\}
$$

$\mathrm{e}$

$$
\varepsilon_{B}(f)=\min \left\{f(y): y \in B_{x} \cap E\right\}
$$

Os operadores $\delta_{B}^{n}$ e $\varepsilon_{B}^{n}$ dados, para $n>0$ pelas $n-1$ composições sucessivas $\delta_{B}^{n}=\left(\delta_{B}\right)^{n}$ e $\varepsilon_{B}^{n}=$ $\left(\varepsilon_{B}\right)^{n}$, e para $n=0, \delta_{B}^{0}=\iota$ e $\varepsilon_{B}^{0}=\iota$, são chamados, respectivamente, de $n$-dilatação e $n$-erosão por B.

Seja $f$ um elemento de $K^{E}$. Os operadores $\delta_{B, f}$ e $\varepsilon_{B, f}$, de $K^{E}$ em $K^{E}$, dados por $\delta_{B, f}=\delta_{B} \wedge f$ e $\varepsilon_{B, f}=\varepsilon_{B} \vee f$, são chamados dilatação condicional e erosão condicional por $B$ dado $f$.

Seja $n$ um inteiro positivo. A sucessão de $n$ dilatações condicionais $\delta_{B, f}$ (respectivamente erosões condicionais $\left.\varepsilon_{B, f}\right)$, denotada por $\delta_{B, f}^{n}=\delta_{B, f} \delta_{B, f} \ldots \delta_{B, f}\left(\varepsilon_{B, f}^{n}=\varepsilon_{B, f} \varepsilon_{B, f} \ldots \varepsilon_{B, f}\right)$ é chamada $n$-dilatação condicional ( $n$-erosão condicional).

Seja $g$ um elemento de $K^{E}$. Os operadores $\gamma_{B, g}$ e $\phi_{B, g}$, de $K^{E}$ em $K^{E}$, dados por, para todo $f \in K^{E}, \gamma_{B, g}=\delta_{B, f}^{\infty}(g)$ e $\phi_{B, g}=\varepsilon_{B, f}^{\infty}(g)$ são chamados, respectivamente, de inf- e supreconstrução do marcador $g$.

Para toda $f \in K^{E}$, a erosão última, $\varrho_{B}(f)$, de uma função $f$ por um elemento estruturante 
$B$ é dada por $\varrho_{B}(f)=\bigvee\left\{\varepsilon_{B}^{i}(f)-\gamma_{B, \varepsilon_{B}^{i+1}(f)}\left(\varepsilon_{B}^{i}(f)\right)\right\}$ para todo $i \geq 0$.

Os operadores $\gamma_{B}$ e $\phi_{B}$, de $K^{E}$ em $K^{E}$, dados por $\gamma_{B}=\delta_{B} \varepsilon_{B}$ e $\phi_{B}=\varepsilon_{B} \delta_{B}$, são chamados, respectivamente, de abertura e fechamento pelo elemento estruturante $B$.

O operador $\iota-\gamma_{B}$ é chamado top-hat pelo elemento estruturante $B$.

Sejam $A$ e $B$ subconjuntos do quadrado $3 \times 3$. O operador $\nabla_{A, B}$ de $K^{E}$ em $K^{E}$, dado por $\nabla_{A, B}=\delta_{A}-\varepsilon_{B}$ é chamado gradiente morfológico. Esse operador destaca as bordas da imagem.

Seja $t \geq|E|$, e seja $i \mapsto x_{i}$ um processo de numeração dos elementos de $E$, ou seja, uma bijeção de $[1, \ldots, E] \subset \mathbf{N}$ em $E$, e seja $f$ um elemento de $K^{E}$ tal que $f\left(x_{i}\right)=i$ para $x \in E$. O operador $\Lambda_{B}$ de $\{0, t\}^{E}$ em $K^{E}$, dado por, para todo $g \in\{0, t\}^{E}, \Lambda_{B}(g)=\gamma_{B, g \wedge f}(g)$ é chamado rotulação de $g$. Note que, em $\Lambda_{B}(g)$, cada ponto de uma componente conexa [17] de $g$ é associado ao mesmo valor.

Dado um ponto $(a, b) \in E$, definimos $E_{x=a} \subseteq E$ como a linha que corta $E$ na direção vertical passando pela coordenada $(a, b)$, ou seja, $E_{x=a}=\{(x, y) \in E: x=a\}$. De modo similar, podemos definir $E_{y=b}=\{(x, y) \in E: y=b\}$ como a linha que corta $E$ na direção horizontal passando pela coordenada $(a, b)$.

Dada uma imagem $f: E \rightarrow K$, sua projeção horizontal, denotada por $P_{h}(f)$, é a função de $E_{x=0}$ em $\mathbf{Z}$, tal que, para todo $(0, i) \in E_{x=0}$,

$$
P_{h}(f)(0, i)=\sum_{p \in E_{y=i}} f(p)
$$

De forma análoga, podemos definir a projeção vertical de $f$, denotada por $P_{v}(f)$, como a função de $E_{y=0}$ em $\mathbf{Z}$, tal que, para todo $(i, 0) \in E_{y=0}$,

$$
P_{v}(f)(i, 0)=\sum_{p \in E_{x=i}} f(p)
$$

Um máximo (ou mínimo) regional $M \subset E$ de uma função $f \in K^{E}$ é uma componente conexa com um dado valor $f(p)=h, \forall p \in M$ (platô no nível de $h$ ) tal que todo ponto na vizinhança de $M$ tem um valor estritamente menor (maior) que $h$. Os máximos e mínimos regionais são dados 
pelos operadores morfológicos $\varrho_{B}^{\max }$ e $\varrho_{B}^{\min }$. A vizinhança de um ponto é definida pelo elemento estruturante $B$.

Dada uma imagem $f$, o threshold de $f$ por $c$, denotado por $\tau_{c}(f)$, é a função de $E$ em $\{0,1\}$ dada por, para todo $x \in E$,

$$
\tau_{c}(f)(x)= \begin{cases}1 & \text { se } f(x) \geq(c) \\ 0 & \text { caso contrário }\end{cases}
$$

Seja $x$ um valor real ou inteiro qualquer, seu módulo, denotado por $|x|$ é igual a $x$ se $x$ for maior ou igual a zero e $-x$ se $x$ for menor que zero. A distância city-block entre dois pontos $\left(x_{0}, y_{0}\right)$ e $\left(x_{1}, y_{1}\right)$ é dada por $\left|x_{0}-x_{1}\right|+\left|y_{0}-y_{1}\right|$.

\subsubsection{Paradigma de Beucher-Meyer}

Esse operador é também conhecido como watershed [18, 19]. É um operador que identifica os contornos da imagem, ou seja, regiões de mudança de intensidade, onde o gradiente é maior. Este operador é muito robusto pois seu resultado não depende de parâmetros além das imagens de entrada, e é capaz de identificar contornos mesmo que o gradiente seja próximo de zero.

Dado o gradiente $f$ de uma imagem que contém o assunto a ser segmentado, e uma imagem $g$ binária, com marcadores que identifiquem as regiões que devem ser separadas, o algoritmo encontra os pontos de maior intensidade em $f$ que separam as duas regiões. Este operador é denotado por $\Omega(\nabla(f), g)$.

\subsection{Gradeamento automático dos blocos}

A segmentação dos blocos consiste em encontrar a posição correta e os limites de cada bloco. É realizada aplicando-se vários filtros aos perfis horizontal e vertical da imagem da lâmina de microarray. O perfil vertical (horizontal) é calculado somando-se os valores de cada coluna (linha) de pontos da imagem original (Figura 3.1). Caso haja mais de um canal, usa-se a média entre eles. 


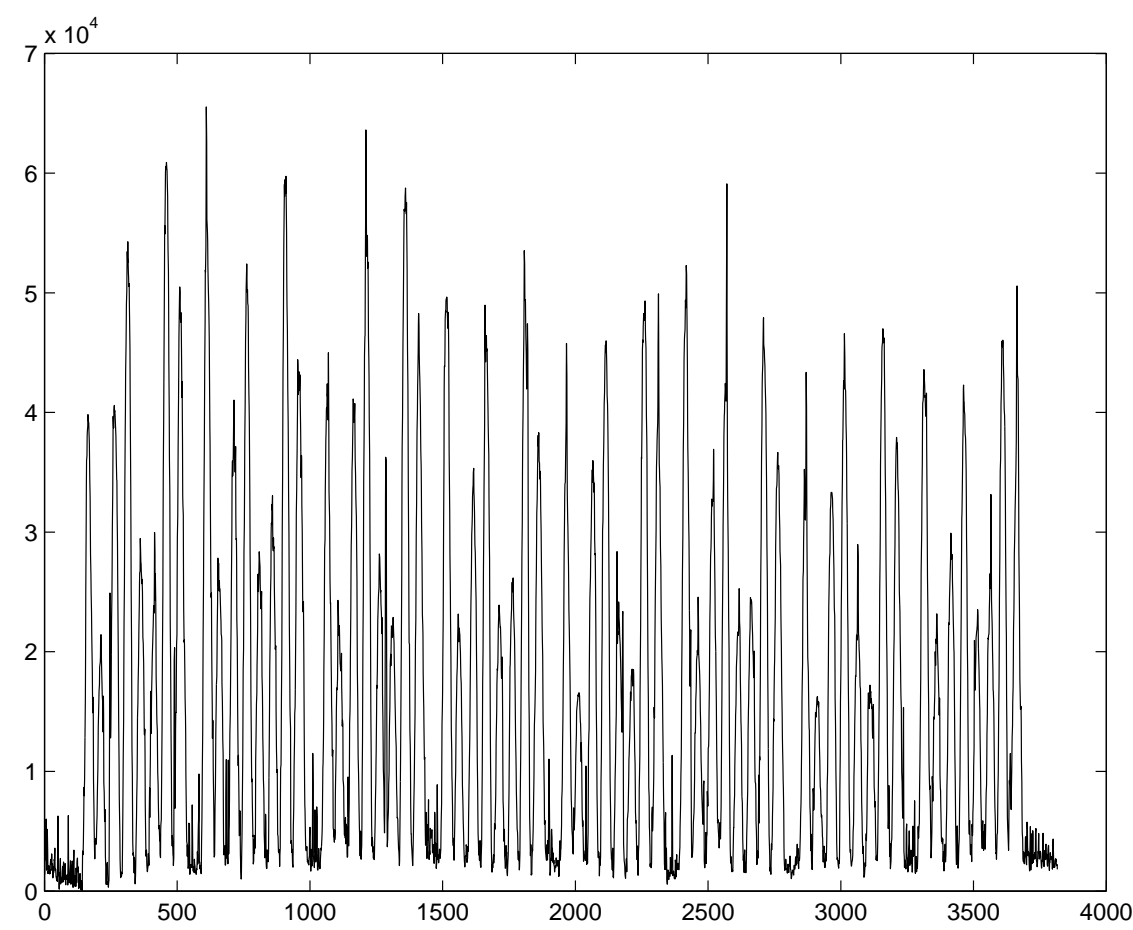

Figura 3.1: Exemplo de perfil vertical.

Se a lâmina for impressa e digitalizada com o mesmo ângulo de inclinação, será possível ver que os spots estarão alinhados paralelamente às bordas da imagem. Nesse caso, nos perfis são facilmente visíveis grupos de picos estreitos nas regiões onde os blocos se encontram.

O perfil vertical dá as linhas verticais da grade de blocos, e o horizontal, as linhas horizontais.

O primeiro passo da filtragem (Figura 3.2) é aplicar um fechamento morfológico por um elemento estruturante linear simétrico de tamanho maior que a distância entre os spots mas menor que a distância entre os blocos aos perfis da imagem. Este operador agrupa perfis de spots pertencentes ao mesmo bloco.

O segundo passo (Figura 3.3) é uma abertura morfológica por um elemento estruturante linear simétrico de tamanho igual a algumas distâncias entre spots. Esta operação apaga picos estreitos, e deixa os picos mais largos que correspondem às regiões dos blocos.

Em seguida, calcula-se a negação dos mínimos locais. É um gráfico binário que vale zero nas regiões entre os blocos. O passo seguinte é eliminar os componentes conexos que tocam a borda 


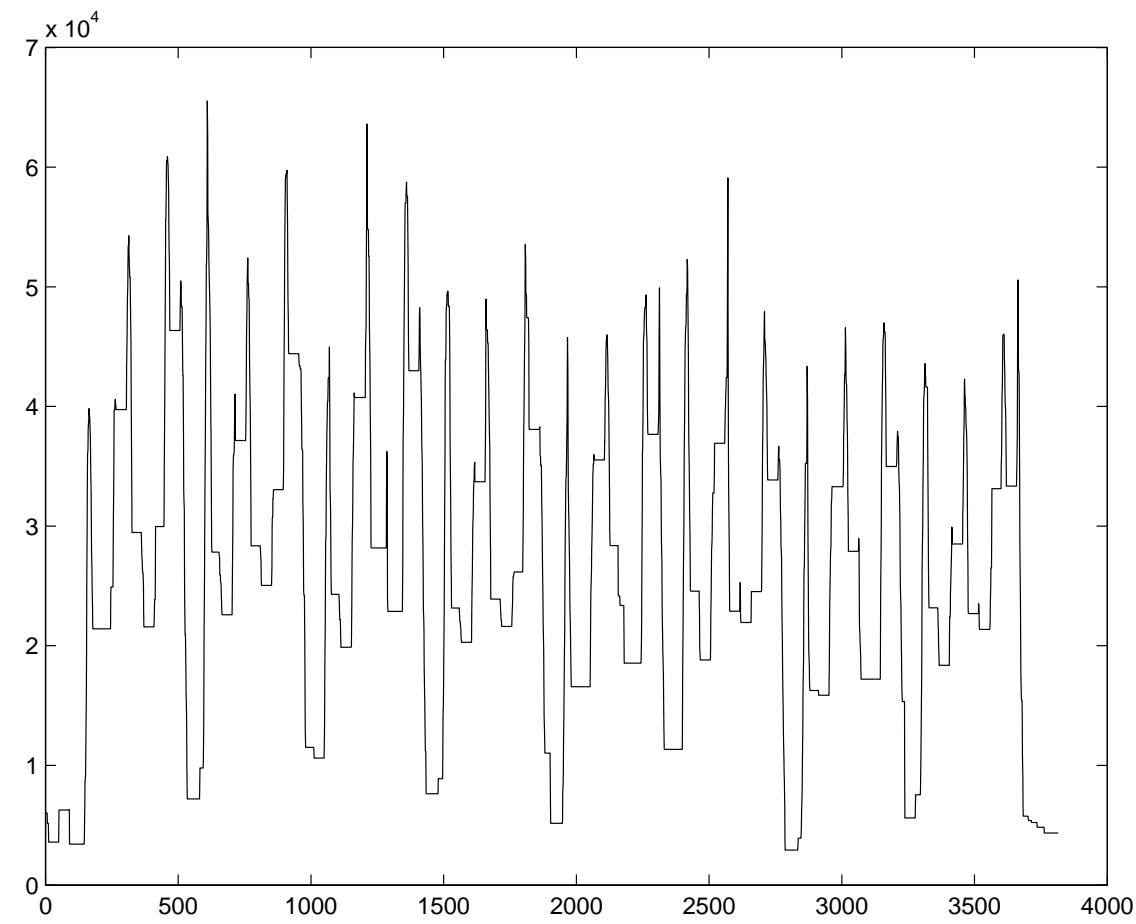

Figura 3.2: Resultado do primeiro filtro.

do gráfico. Esse passo é importante especialmente em imagens com borda ruidosa, já que nesses casos é comum que tal ruído seja identificado como região pertencente a um bloco (Figura 3.4).

Em geral, nesse ponto do processo, boas imagens já permitem obter uma boa aproximação da segmentação dos blocos. No entanto, imagens ruidosas são muito comuns e adicionamos um passo de correção baseado na geometria da lâmina. Esse passo é acionado quando a diferença entre o tamanho estimado de algum bloco ou distância entre blocos e o respectivo tamanho teórico, fornecido pelo usuário no início do processo, é maior que uma certa tolerância. A tolerância usada é igual a meia distância entre centros de spots adjacentes.

A posição final do bloco é tal que satisfaça a tolerância, maximizando o valor médio do perfil dentro de uma região igual ao tamanho teórico do bloco. É de se esperar que, se o bloco for mal centralizado, o valor médio do perfil será baixo já que está incluída uma região do perfil entre blocos.

A Figura 3.5 mostra quatro gráficos superpostos, em unidades arbitrárias. De cima para 


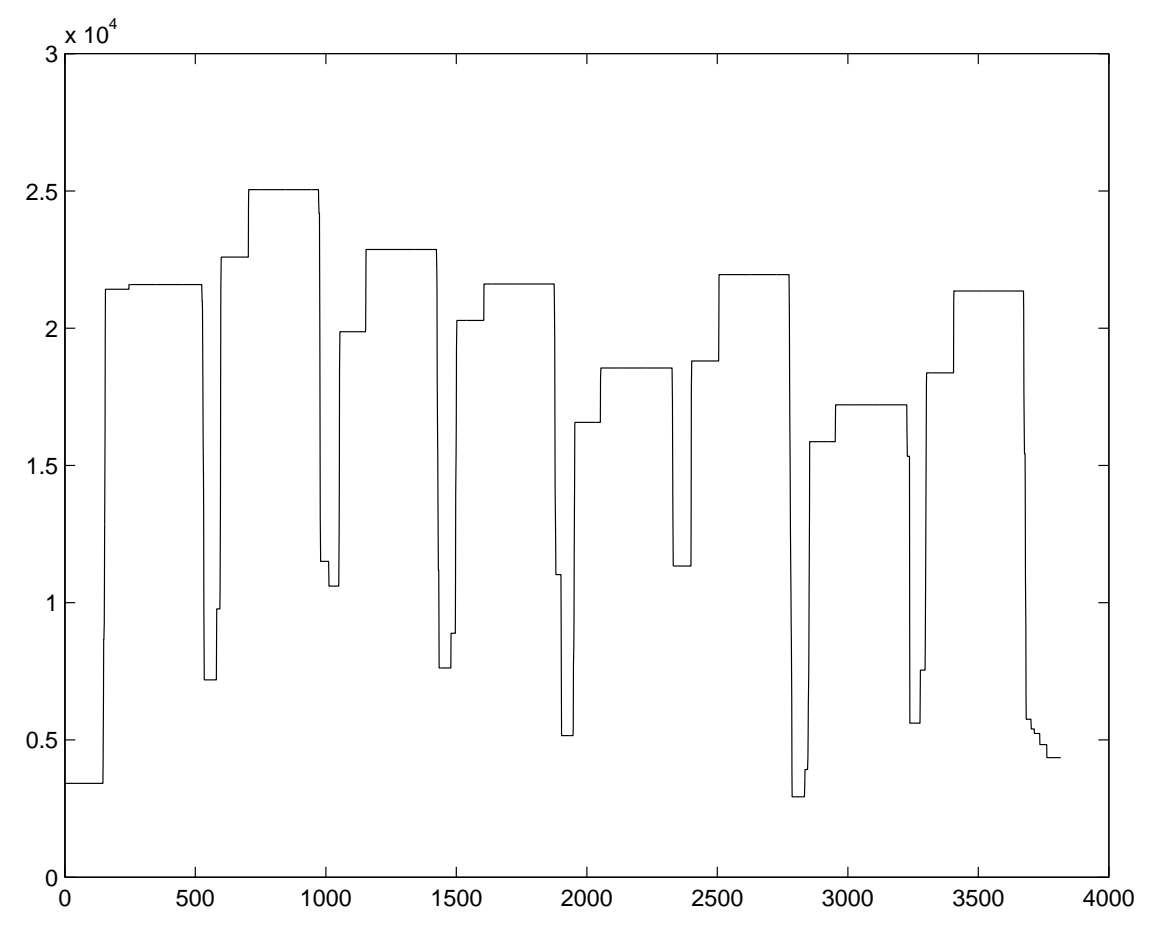

Figura 3.3: Resultado do segundo filtro.

baixo, perfil médio na região igual ao tamanho teórico do bloco começando naquele ponto; perfil da imagem; posições dos blocos calculadas pelos filtros morfológicos; e posições dos blocos calculadas por esse passo de correção.

O algoritmo se baseia nas posições dos blocos que satisfazem a tolerância para calcular as novas posições dos que foram considerados errados. Além disso, usa informações do perfil, o que o torna mais robusto. Quando há vários blocos errados em seqüência, o algoritmo se baseia no bloco mais próximo do centro, que é a região menos sujeita a ruído.

Quando todos os blocos são considerados errados, o algoritmo calcula a curva do valor médio do perfil no interior dos blocos segundo dois parâmetros: i - início do primeiro bloco; e ii espaçamento entre os blocos que obedecem a tolerância (teórico mais ou menos meia distância entre spots). O tamanho do bloco usado é o teórico, fornecido pelo usuário. Os parâmetros do ponto máximo da curva são os escolhidos como a segmentação correta dos blocos. 


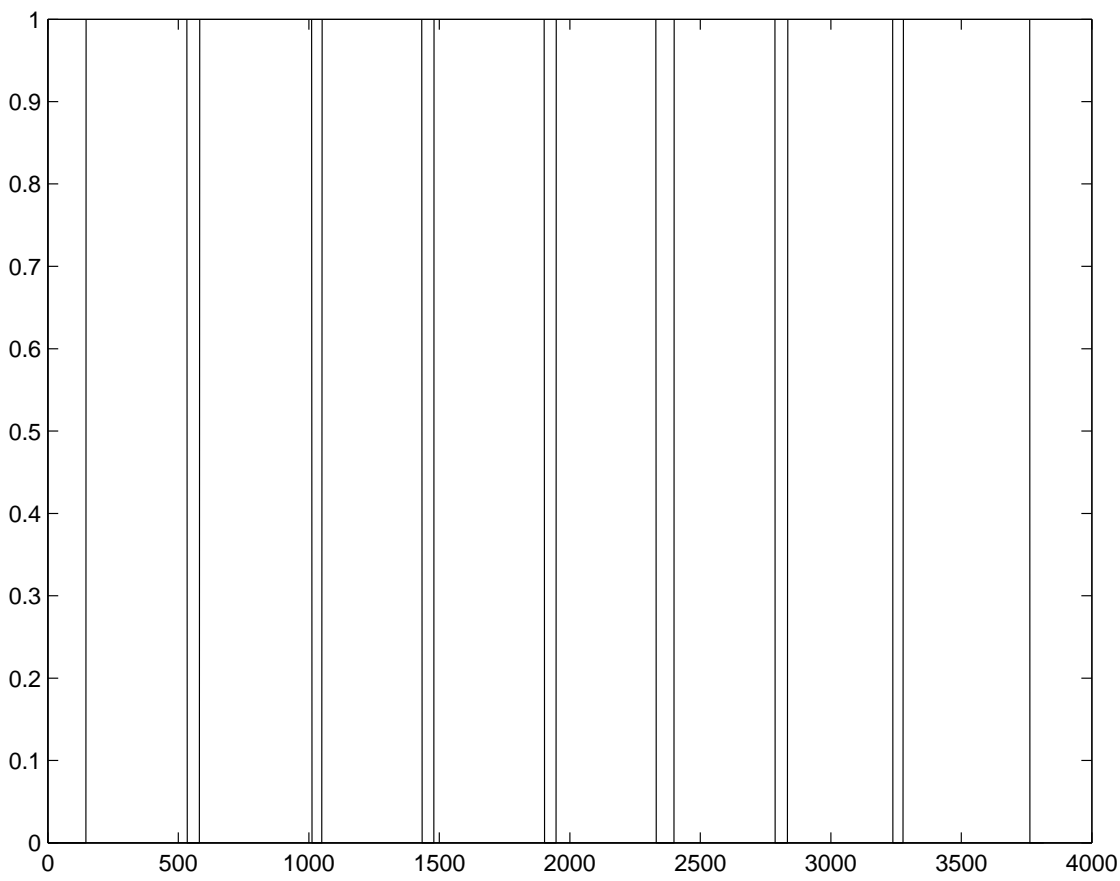

Figura 3.4: Fronteiras dos blocos.

\subsection{Gradeamento automático dos spots}

Para calcular o gradeamento dos spots, o algoritmo se baseia na segmentação dos blocos. O cálculo também é feito baseado nos perfis, mas agora de cada bloco, individualmente. O programa calcula os perfis $f_{i}$, onde $i$ é o índice do bloco, os filtra e toma os mínimos regionais como as linhas de grade. A diferença é que a filtragem é muito mais simples que a da segmentação dos blocos. Os spots são responsáveis pelos valores mais altos do perfil, e o background, pelos valores mais baixos.

As figuras 3.6 (a) e 3.7 (a) mostram os perfis do bloco na Figura 3.8 sendo segmentado. Embora simples, a filtragem é necessária para eliminar mínimos locais que podem aparecer entre os mínimos realmente interessantes que indicarão a posição da grade. A filtragem elimina mínimos locais causados por ruído que podem aparecer, tanto nos picos do perfil, quanto próximos ao fundo dos vales entre fileiras de spots.

A filtragem é simplesmente uma abertura por um elemento estruturante $B_{n}$ linear, onde $n$ 


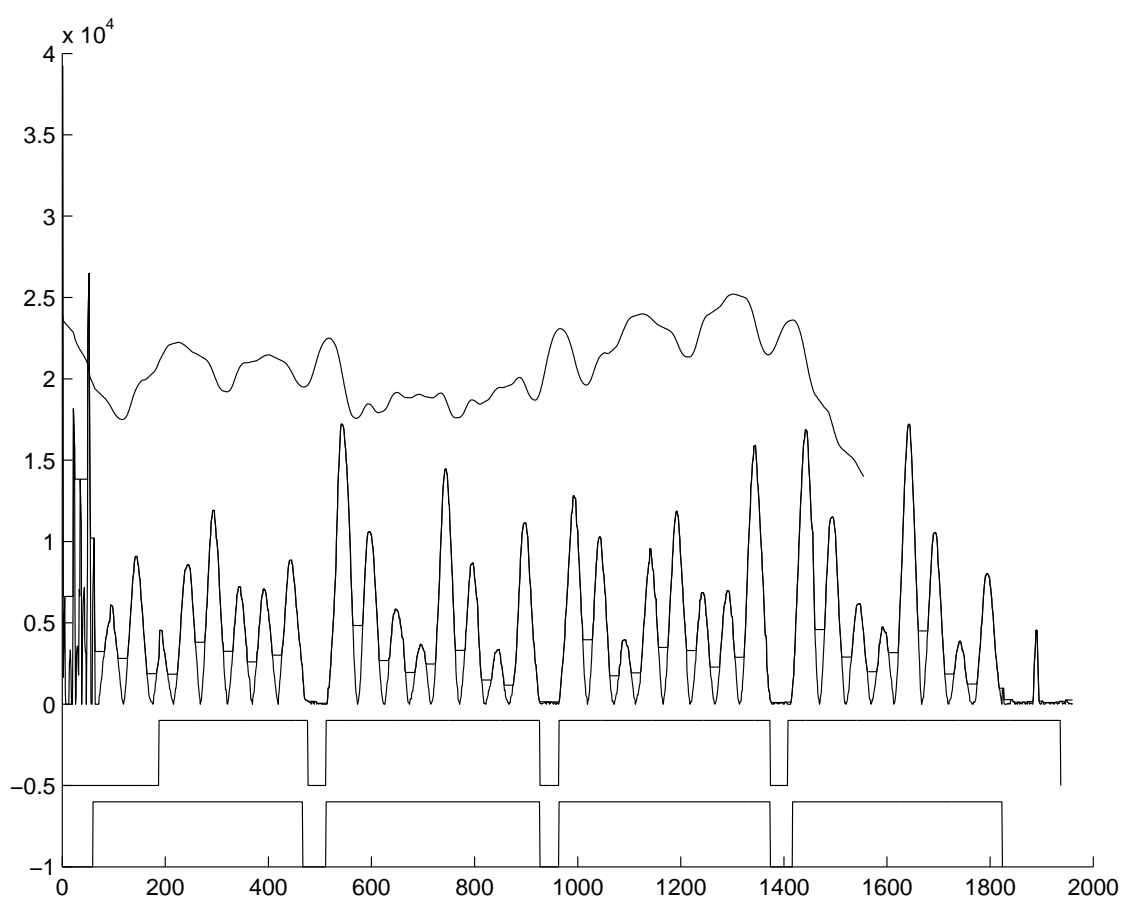

Figura 3.5: Correção da segmentação morfológica.

é aproximadamente igual ao diâmetro médio do spot. As figuras 3.6 (b) e 3.7 (b) mostram o resultado da filtragem aplicada aos perfis do bloco.

O passo seguinte é calcular os mínimos regionais do perfil filtrado. Essa operação dará um conjunto de pontos não nulos que indicam a posição da grade. As figuras 3.6 (c) e 3.7 (c) mostram o resultado do cálculo dos mínimos regionais do passo anterior. Em 3.6 (d) e 3.7 (d) temos as grades resultantes e finalmente em 3.9, a composição das grades com a imagem original do bloco.

A equação abaixo mostra todos os passos do processo para o perfil horizontal de bloco $f$, indicado por $P_{h}(f)$.

$$
M_{h}=\varrho_{B}^{\min }\left(\gamma_{B_{n}}\left(P_{h}(f)\right)\right)
$$

A grade vertical, indicada por $M_{v}$, é calculada por um processo similar. 

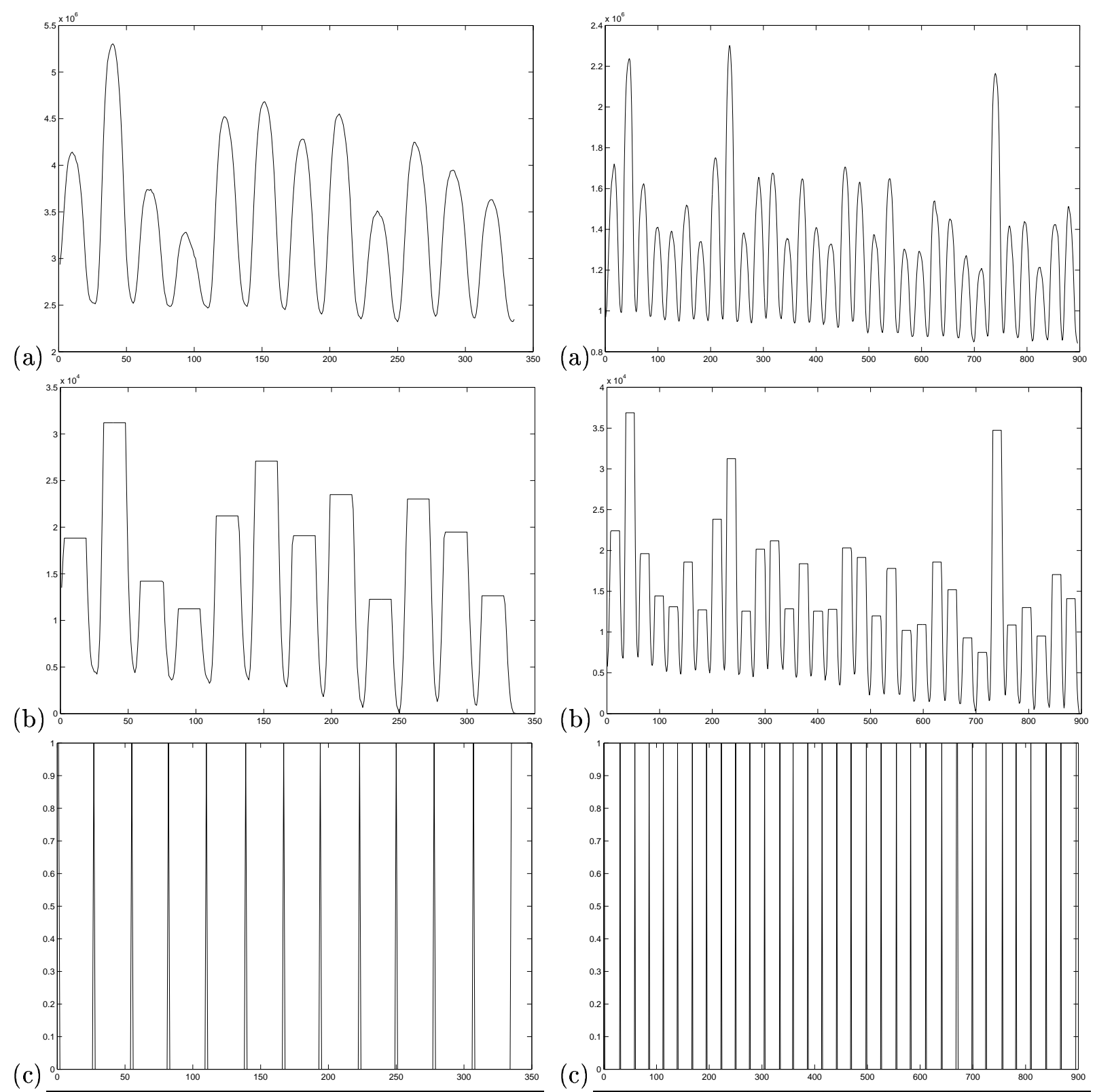

(d)
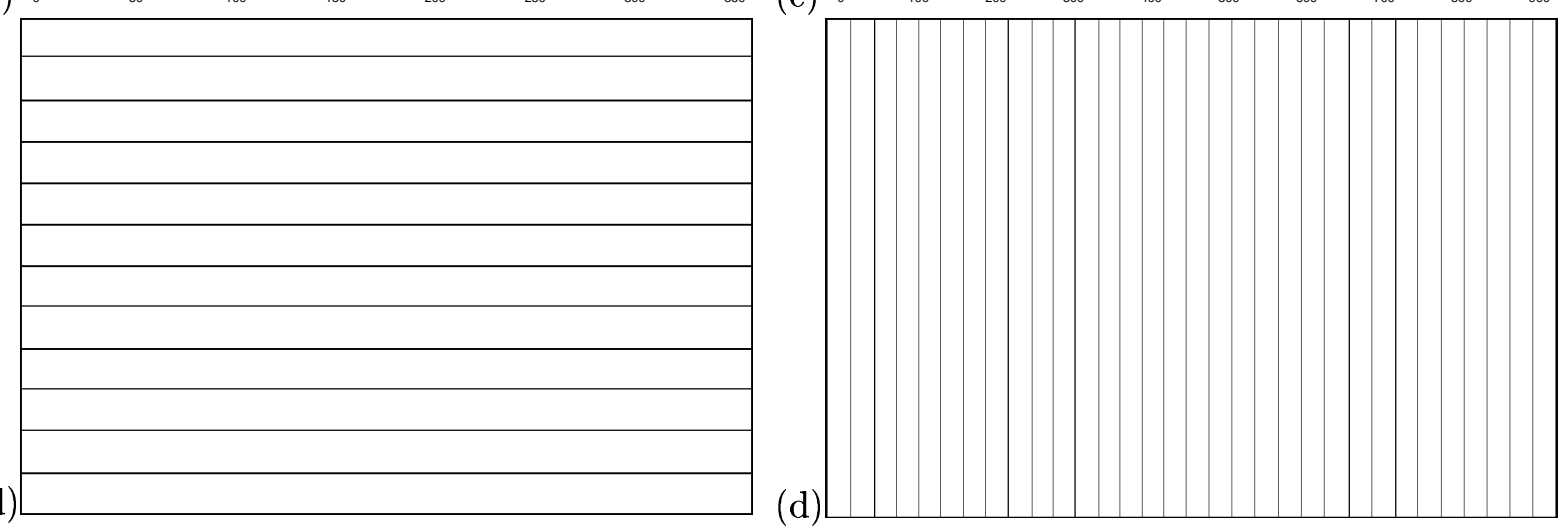

Figura 3.6: Gradeamento horizontal.

Figura 3.7: Gradeamento vertical. 


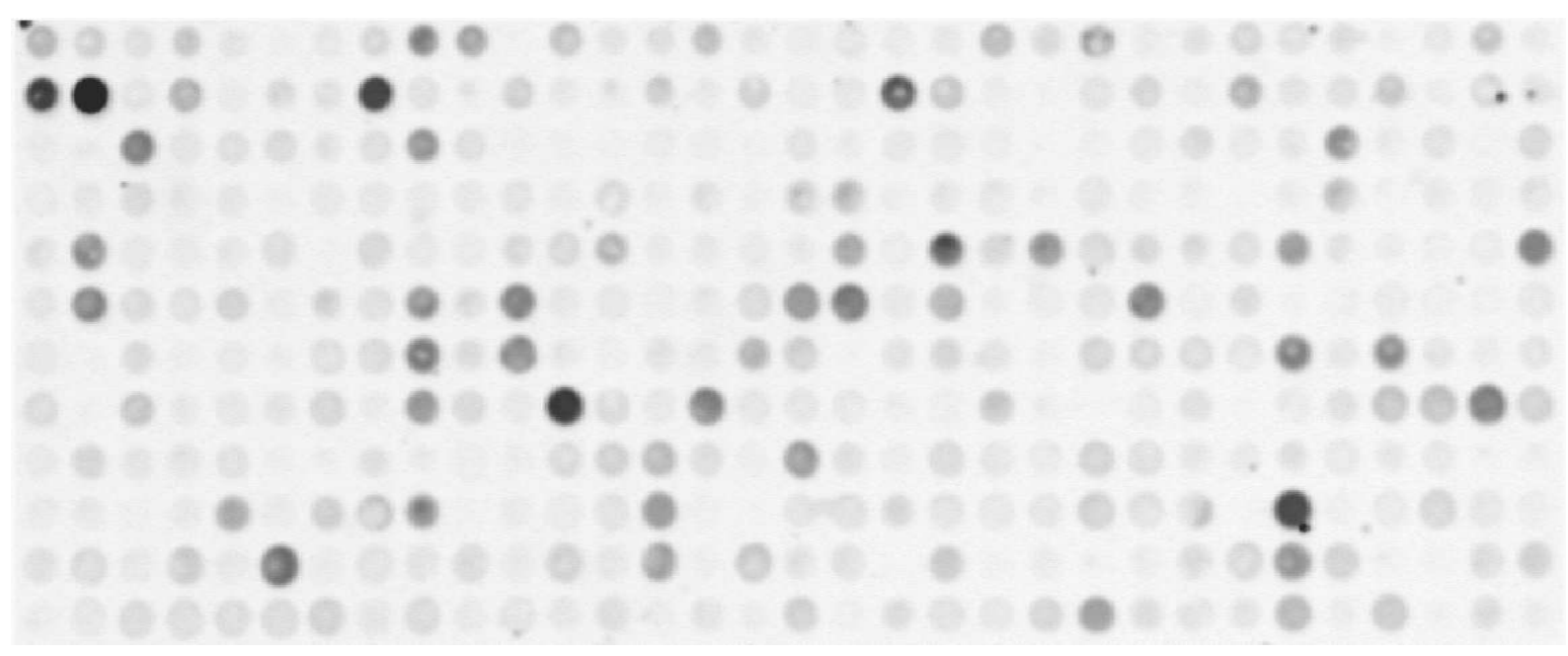

Figura 3.8: Primeiro bloco do microarray da Fig. 2.4.

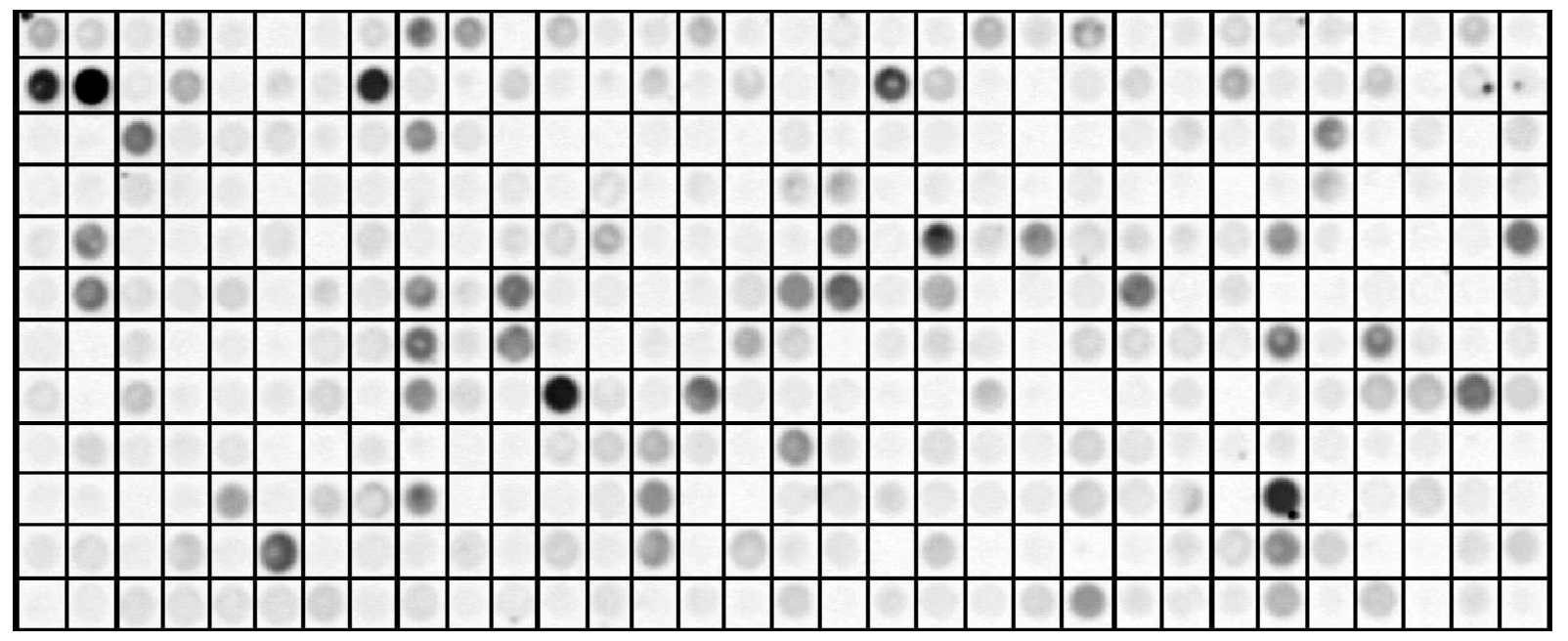

Figura 3.9: Composição das linhas de grade com o bloco da Fig. 3.8.

A posição dos elementos não nulos encontrados em $M_{h}$ e $M_{v}$, se armazenadas em um vetor, podem ser usadas facilmente para indicar a região de interesse de qualquer spot daquele bloco. Seja $J_{h}$ a seqüência de índices tais que $j \in J_{h}$ se $M_{h}(j) \neq 0$. O $J_{h}$ é uma seqüência de índices que indicam onde as linhas horizontais da grade estão localizadas. As linhas verticais, indicadas por $J_{v}$ são calculadas de forma equivalente.

Os pixels da linha $m$ de $s p o t s$ são todos os que têm coordenadas maiores que $J_{h}(m)$ e menores 
que $J_{h}(m+1)$. Similarmente, os pixels da coluna $n$ de spots são todos os que têm coordenadas maiores que $J_{v}(n)$ e menores que $J_{v}(n+1)$. Os valores de $m$ e $n$ variam, respectivamente, de 1 até o número de linhas e colunas de spots por bloco.

Para encontrar em um bloco a região de interesse de um único spot, localizado na linha $m$ e na coluna $n$, basta escolher a interseção dos pixels da linha e coluna respectivas, ou seja, os pixels do conjunto $\left\{(x, y): J_{v}(n)<x<J_{v}(n+1)\right.$ e $\left.J_{h}(m)<x<J_{h}(m+1)\right\}$.

\subsubsection{Passo de correção}

O método morfológico mostrado é robusto e produz resultados corretos para diversas das imagens testadas. No entanto, devido a defeitos nos contornos dos spots (contaminações por partículas de poeira, hibridização irregular, erro na manipilação etc) o método pode não funcionar corretamente.

A Figura 3.10(a) mostra a imagem de um bloco que contém um defeito bastante grande, provavelmente causado por alguma partícula de poeira depois da impressão ou da hibridização. Esse defeito causou dois tipos diferentes de problema de gradeamento: há uma linha horizontal extra particionando uma linha de spots, apontada por um triângulo grande, e uma linha vertical não foi encontrada na posição apontada por um triângulo pequeno.

Uma forma de corrigir esses erros seria filtrando os resultados do gradeamento usando conhecimento prévio a respeito da geometria da lâmina, como o número de spots em cada linha ou coluna, diâmetro e espaçamento entre eles. Como essa informação já foi fornecida pelo usuário, o processo pode continuar sem sua interferência.

O algoritmo de correção primeiro apaga as linhas muito próximas entre si, ou que aparentam estar mal posicionadas, e em seguida adiciona novas linhas entre as que estiverem muito distantes. Sejam $E_{h}$ e $E_{v}$ as dimensões horizontal e vertical em pixels da imagem do bloco. Seja $n_{h}$ o número de spots em cada linha do bloco, e $d_{h}$ a distância média entre cada linha da grade naquele bloco, ou seja, $d_{h}=E_{h} / n_{h}$. A distância média entre as linhas de grade que segmentam o bloco na vertical é $d_{v}=E_{v} / n_{v}$, onde $n_{v}$ é o número de spots em cada coluna do bloco.

Sejam $J_{v}$ e $J_{h}$ seqüências de índices que identificam onde as linhas horizontais e verticais da 
grade estão localizadas, conforme definido no final da seção 3.4. Definimos $\Delta J_{h}$ como a seqüência das diferenças entre a posição de uma linha e a seguinte, ou seja, $\Delta J_{h}[i]=\left|J_{h}[i+1]-J_{h}[i]\right|$, $i \in\left[1,\left|J_{h}\right|-1\right]$. A Figura 3.11 mostra $J_{h}$ (seqüência de cima) e respectivo $\Delta J_{h}$ (seqüência de baixo) para as linhas horizontais da imagem mostrada na Figura 3.10(a).

Se a diferença $\Delta J_{h}[i]$ for menor que $d_{h} / 2$, então uma das linhas, $J_{h}[i]$ ou $J_{h}[i+1]$, está mal posicionada e deve ser apagada. O mesmo vale para as linhas verticais. Para decidir qual linha deve ser apagada, usamos uma função de custo que avalia as distâncias entre duas linhas sucessivas. Seja $l$ a função de custo definida em $\mathbf{R}$ por

$$
l_{z}(t)= \begin{cases}0.5 & \text { se } t \leq \frac{d_{z}}{2} \\ \left|\operatorname{round}\left(\frac{t}{d_{z}}\right)-\frac{t}{d_{z}}\right| & \text { caso contrário }\end{cases}
$$

onde $\operatorname{round}(\cdot)$ é o arredondamento para o inteiro mais próximo de $(\cdot), z$ é igual a $h$ ou $v$ se referente às linhas horizontais ou verticais da grade respectivamente. A Figura 3.12 é um exemplo de gráfico da função de custo para $d_{z}=10$ e $t \in[1,100]$.

Para definir a função de custo, supomos que é mais provável que uma linha esteja separada de outra por $k d_{z}$ pixels, $k$ inteiro. Tais linhas devem ter um custo próximo de zero. Por outro lado, é menos provável que uma linha esteja separada de outra por $k+\frac{1}{2} d_{z}$, portanto o seu custo é mais alto.

O algoritmo que apaga linhas é executado para todas as linhas $i$ para as quais $\Delta J_{z}[i-1]<$ $d_{z} / 2$, exceto para a primeira e duas últimas linhas. Supomos que a primeira e a última linhas estão corretas. A penúltima linha, de índice $i-1$ é avaliada em separado: se $\Delta J_{z}[i-1]<d_{z} / 2$, a tal linha é apagada. O algoritmo recebe os seguintes parâmetros:

- $n_{z}$ — número de spots por fileira.

- $d_{z}$ - distância média entre linhas.

- $J_{z}$ - seqüência de posições iniciais das linhas.

- $\Delta J_{z}$ - seqüência de distâncias iniciais entre as linhas de $J_{z}$.

No final, temos um novo $J_{z}$ com o resultado corrigido. O símbolo "\" nas linhas 6 e 8 indica que o elemento $J_{z}[i]$ da seqüência $J_{z}[]$ está sendo eliminado. 
Algoritmo 1. Algoritmo para apagar linhas.

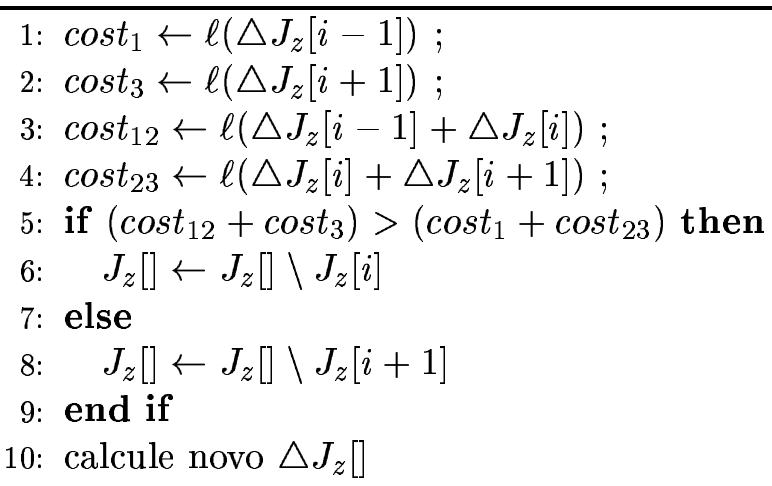

O algoritmo verifica se a diferença entre as linhas $J_{z}[i]$ e $J_{z}[i-1]$, onde $2 \leq i \leq\left|J_{z}\right|-2$ é muito pequena, ou seja, se é menor que metade da distância teórica $d_{z}$ entre as linhas. Em caso afirmativo, ou a linha $i$ ou a linha $i+1$ é eliminada. A escolha é baseada na função de custo $\ell$ aplicada às diferenças $\Delta J_{z}$. Por exemplo, na Figura 3.11 temos, para $i=2, \Delta J_{h}[1]=2$, $\Delta J_{h}[2]=54$ e $\Delta J_{h}[3]=1$. O valor de $d_{h}$ é 48,75. Assim, temos $\operatorname{cost}_{1}=0,5 ; \operatorname{cost}_{3}=0,5$; $\operatorname{cost}_{12}=0,1487$ e $\operatorname{cost}_{23}=0,1282$. Como $\left(\operatorname{cost}_{12}+\operatorname{cost}_{3}\right)>\left(\operatorname{cost}_{1}+\operatorname{cost}_{23}\right)$, o algoritmo elimina a linha $J_{h}[2]$.

Antes de adicionar linhas, o algoritmo verifica se o número de linhas já está certo, ou seja, se já há $n_{z}+1$ linhas. $\mathrm{O}$ algoritmo insere linhas iterativamente enquanto seu número for menor que $n_{z}+1$.

Para inserir uma linha, procuramos o índice $i$ com o maior valor de $\Delta J_{z}[i]$. Encontrado o índice, consideramos duas formas: uma é inserir algumas linhas entre $J_{z}[i]$ e $J_{z}[i+1]$, e a outra é excluir $J_{z}[i+1]$ e inserir linhas entre $J_{z}[i]$ e $J_{z}[i+2]$. Escolhemos a alternativa que produza a menor soma de custos.

As linhas são inseridas sempre uniformemente espaçadas entre si, e o número de linhas é calculado de forma que tais espaços sejam próximos de $d_{z}$. Ou seja, o algoritmo percebe se entre duas linhas é melhor inserir uma ou mais. O número de linhas a serem inseridas entre:

- $J_{z}[i]$ e $J_{z}[i+1]$ é $\operatorname{round}\left(\Delta_{z}[i] / d_{z}\right)-1$.

- $J_{z}[i]$ e $J_{z}[i+2]$ é $\operatorname{round}\left(\left(\Delta_{z}[i]+\Delta_{z}[i+1]\right) / d_{z}\right)-1$. 
O algoritmo também pára quando tenta todos os $i$ sem inserir nenhuma linha.

A Figura 3.10(b) mostra o resultado do procedimento que apaga linhas (a linha apagada aparece em preto e as demais em branco), e a Figura 3.10(c) mostra a correção final após o procedimento que adiciona linhas. Observe que o procedimento apagou uma linha vertical e inseriu duas outras.

As figuras 3.13(a), 3.13(b), 3.14(a) e 3.13(b) mostram o gradeamento morfológico e subseqüente correção de dois outros blocos. Na Figura 3.13(a) estão faltando a segunda linha horizontal e a quarta linha vertical. Na Figura 3.14(a), a terceira linha horizontal está mal posicionada.

Um defeito desse algoritmo é que ele, ao contrário do algoritmo de correção do gradeamento dos blocos, não aproveita a informação do perfil, o que pode ocasionar erros nas grades, especialmente em blocos com muitas fileiras de spots.

\subsection{Segmentação dos spots}

Este é o último passo da segmentação. Os pinos do robô que imprime a lâmina são cilíndricos, assim, espera-se que as regiões que contêm o sinal de cada spot sejam aproximadamente circulares. Porém, devido a diferentes condições físicas e químicas, seja na impressão e secagem da lâmina, seja na hibridização, tais regiões podem acabar não tão regulares. Irregularidades nos contornos e na intensidade dentro da região do spot são comuns. Geralmente os programas comerciais assumem que as regiões do sinal são sempre círculos ou elipses perfeitos e o ajuste do raio e forma é feito com muita interação do usuário.

Uma abordagem simples para a segmentação dos spots é o operador top-hat. Dada a imagem $f$ a segmentação seria dada pela expressão $\tau_{c}\left(\iota-\gamma_{B_{s}}\right)(f)$, onde $\gamma_{B_{s}}$ é uma abertura por $B_{s}$, um elemento estruturante em forma de disco de raio aproximadamente igual ao raio do spot. E $\tau_{c}$ é o operador threshold pelo nível de cinza $c$.

No entanto, tal abordagem não dá bons resultados. Não é fácil ajustar o parâmetro $c$, e a informação da posição da grade não é aproveitada. Para melhorar a segmentação, usamos um 
método que não requeira parâmetros absolutos como o do threshold, e que aproveite a informação da grade. Por apresentar tais características, o método escolhido foi o paradigma de BeucherMeyer, ou watershed [18, 19].

Seja a imagem $f$ a composição dos canais da imagem da lâmina a ser segmentada. O procedimento de segmentação recebe como entrada duas imagens: a primeira é o gradiente morfológico da imagem $f$ após alguma filtragem; e a segunda é uma imagem marcadora $m$, binária, composta pelos centros aproximados dos spots mais a grade. Assumimos que um spot está sempre completamente incluído em um retângulo da grade.

A máscara $m$ é calculada pela seguinte expressão:

$$
m=g \vee \varrho_{B_{s}}\left(\varrho_{B_{4}}^{\max }\left(\gamma_{B_{n}}\left(\left(\iota-\gamma_{B_{s}}\right)(f)\right)\right)\right)
$$

onde $g$ é uma imagem com a grade, calculada conforme descrito na última seção. É uma imagem binária com linhas verticais e horizontais com um único pixel de espessura, que particiona o bloco em fileiras verticais e horizontais de spots. O lado direito da união calcula o centro aproximado de cada spot. $\mathrm{O}$ elemento estruturante $B_{s}$ é um círculo com raio aproximadamente igual ao raio médio dos spots, e $B_{n}$ é também um disco de raio igual a um terço do raio do spot, usado para filtrar o ruído.

A imagem $f$ é filtrada com uma abertura morfológica que elimina pequenas irregularidades devidas ao ruído. Seja $h=\gamma_{B_{n}}(f)$ o resultado de tal filtragem, a segmentação dos spots é dada por

$$
s=\Omega\left(\nabla_{B_{4}}(h), m\right)
$$

onde $\Omega$ é o operador watershed $[20,21,22]$. e $B_{4}$ é uma cruz elementar, ou seja, uma cruz $3 \times 3$ centrada na origem.

O resultado desta segmentação é uma imagem com uma máscara que indica quais são os pixels do sinal, e é usada na estimação do nível de hibridização. A Figura 3.15 mostra o resultado da 
segmentação da Figura 3.9.

O operador watershed gerou resultados visualmente muito bons, separando bem o sinal dos spots, mesmo os irregulares ou pouco intensos, do background.

A Figura 3.16 mostra o resultado final do nosso software, com o gradeamento e segmentação de uma lâmina de oligonucleotídeos [11].

A Figura 3.17 mostra uma lâmina de membrana e o resultado de seu gradeamento. A Figura 3.18 mostra um exemplo de segmentação de seus spots.

A Figura 3.19 mostra uma lâmina de cDNA onde, apesar de tanto os blocos quanto os spots se apresentarem bastante próximos entre si, o gradeamento foi bem sucedido. A Figura 3.20 mostra um exemplo de segmentação de seus spots.

A Figura 3.21 mostra a segmentação dos spots de um bloco de uma lâmina de genes sintéticos digitalizada a laser. A Figura 3.22 mostra a segmentação dos spots de um bloco de uma lâmina digidalizada por CCD (Charge-Coupled Device). Observe a diferença de contraste entre as duas figuras. 


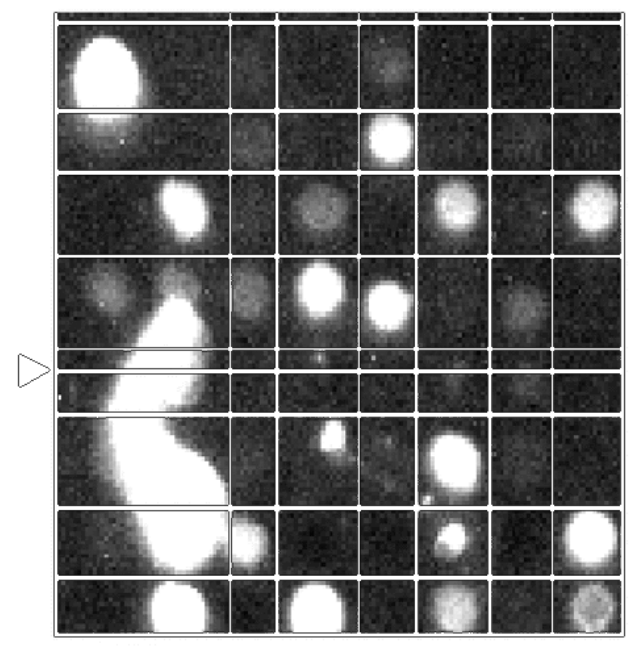

(a)

$\triangle$
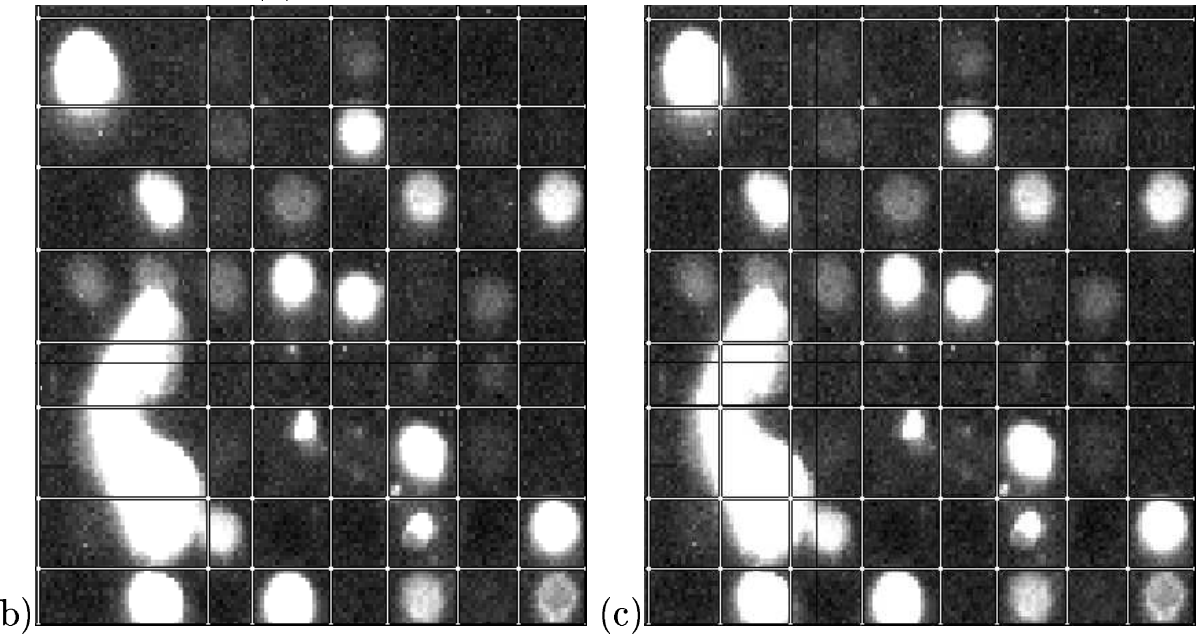

Figura 3.10: (a) Gradeamento morfológico do bloco 6 da lâmina da Figura 2.5. (b) Apagando linhas da grade. (c) Adicionando linhas à grade.

\begin{tabular}{l|l|l|l|l|l|l|l|l|l|l|l|l|l|l|l|l|l|l|l|l|l|l|l|l|l|l|}
18 & 20 & 74 & 75 & 76 & 113 & 114 & 115 & 167 & 168 & 226 & 227 & 239 & 240 & 241 & 267 & 268 & 269 & 326 & 327 & 328 & 370 & 371 & 372 & 406 & 407 & 408 \\
\hline
\end{tabular}

\begin{tabular}{|l|l|l|l|l|l|l|l|l|l|l|l|l|l|l|l|l|l|l|l|l|l|l|l|l|l|}
2 & 54 & 1 & 1 & 37 & 1 & 1 & 52 & 1 & 58 & 1 & 12 & 1 & 1 & 26 & 1 & 1 & 57 & 1 & 1 & 42 & 1 & 1 & 34 & 1 & 1 \\
\hline
\end{tabular}

Figura 3.11: $J_{h}$ e $\Delta J_{h}$ da Figura 3.10(a) 


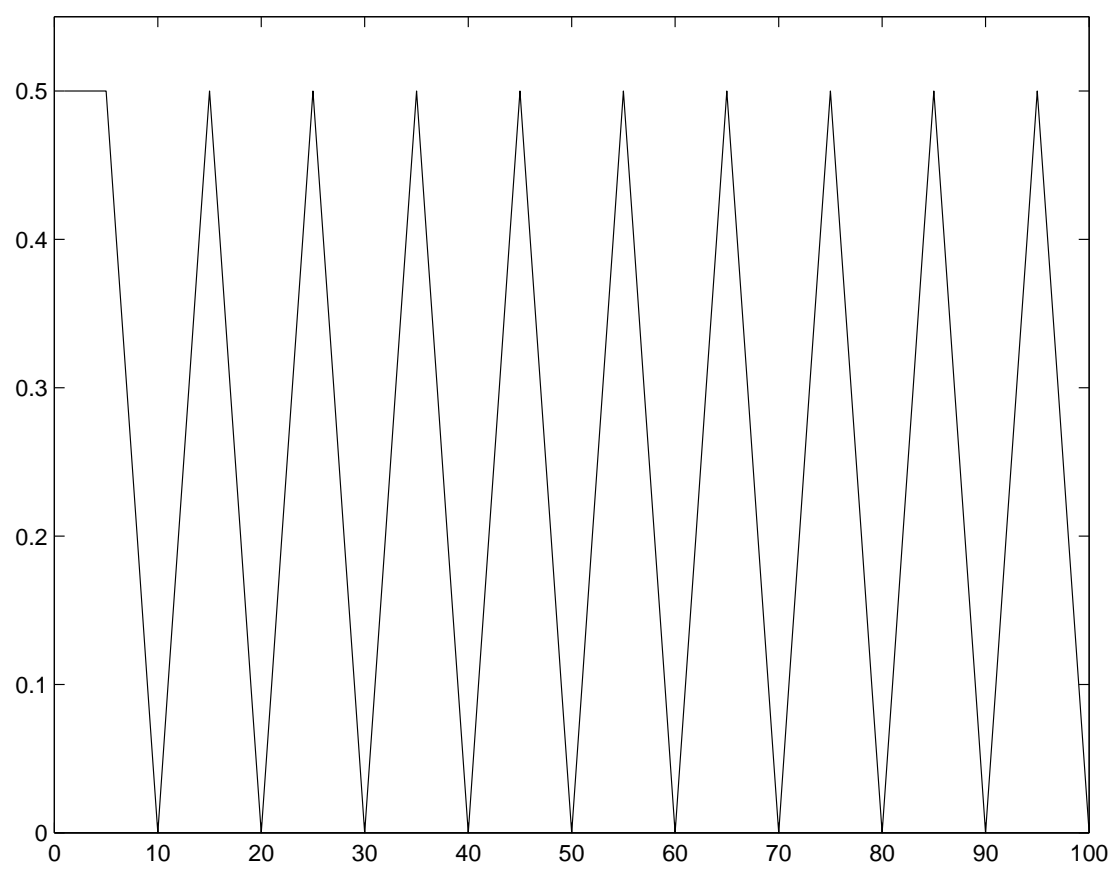

Figura 3.12: Gráfico da função de custo para $d_{z}=10$ e $t \in[1,100]$

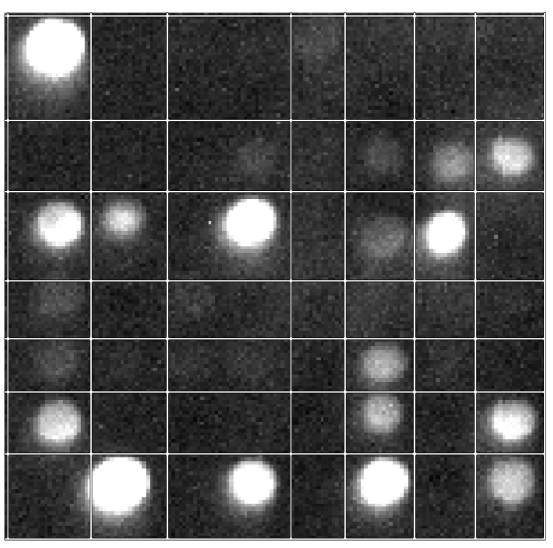

(a)

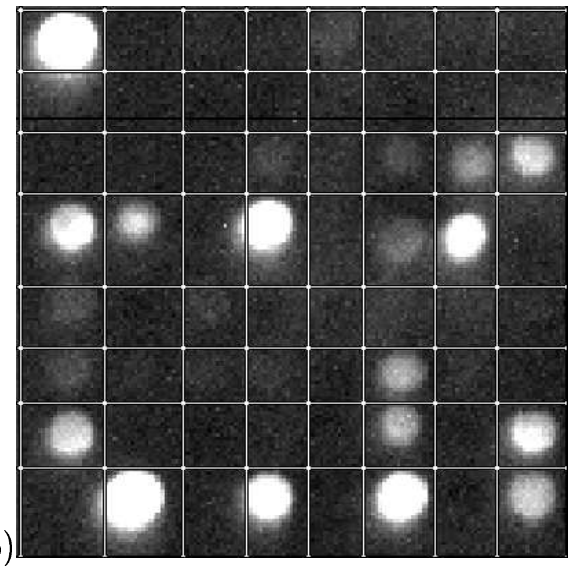

Figura 3.13: (a) Gradeamento morfológico do bloco 4 (linha 1, coluna 4) da lâmina da Figura 2.5. (b) Correção final. 


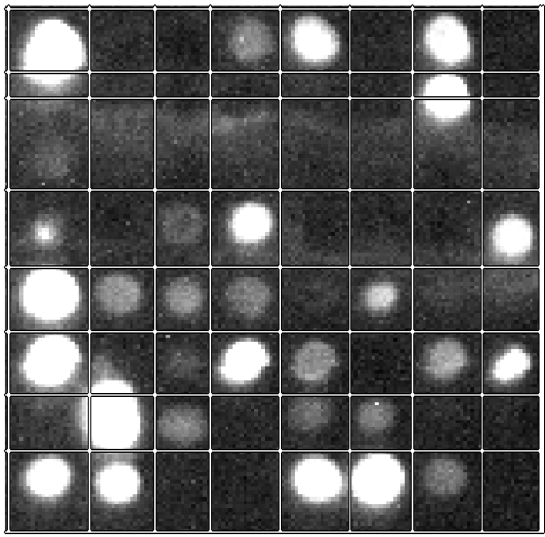

(a)

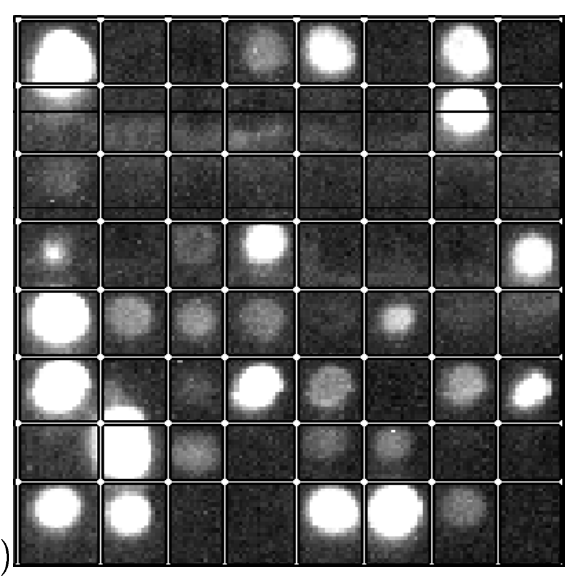

(b)

Figura 3.14: (a) Gradeamento morfológico do bloco 11 (linha 3, coluna 3) da lâmina da Figura 2.5. (b) Correção final.

00000000000000000000000000000000 00000000000000000000000000000000 00000000000000000000000000000000 00000000000000000000000000005000 00000000000000000000000000000000 00000000000000000000000000800000 00000000000000000000000000000000 00000000000000000000000000000000 00000000000000000000000000000000 00000000000000000000000000000000 00000000000000000000000000000000 00000000000000000000000000000000

Figura 3.15: Contorno dos spots da Figura 3.9. 


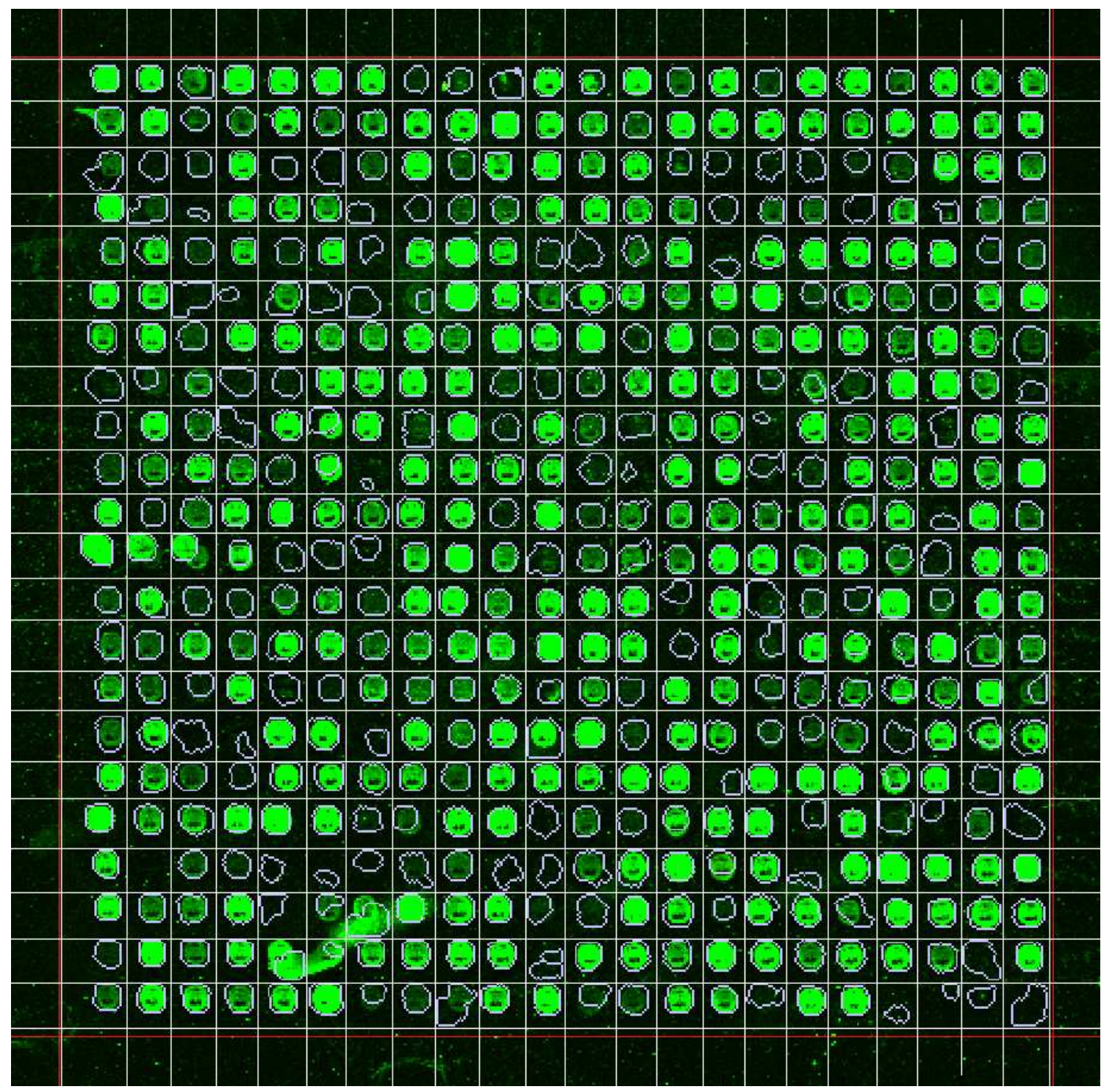

Figura 3.16: Exemplo de segmentação de spots de lâmina de oligonucleotídeos (mos13-083 extraída da página http://derisilab.ucsf.edu/falciparum/). 


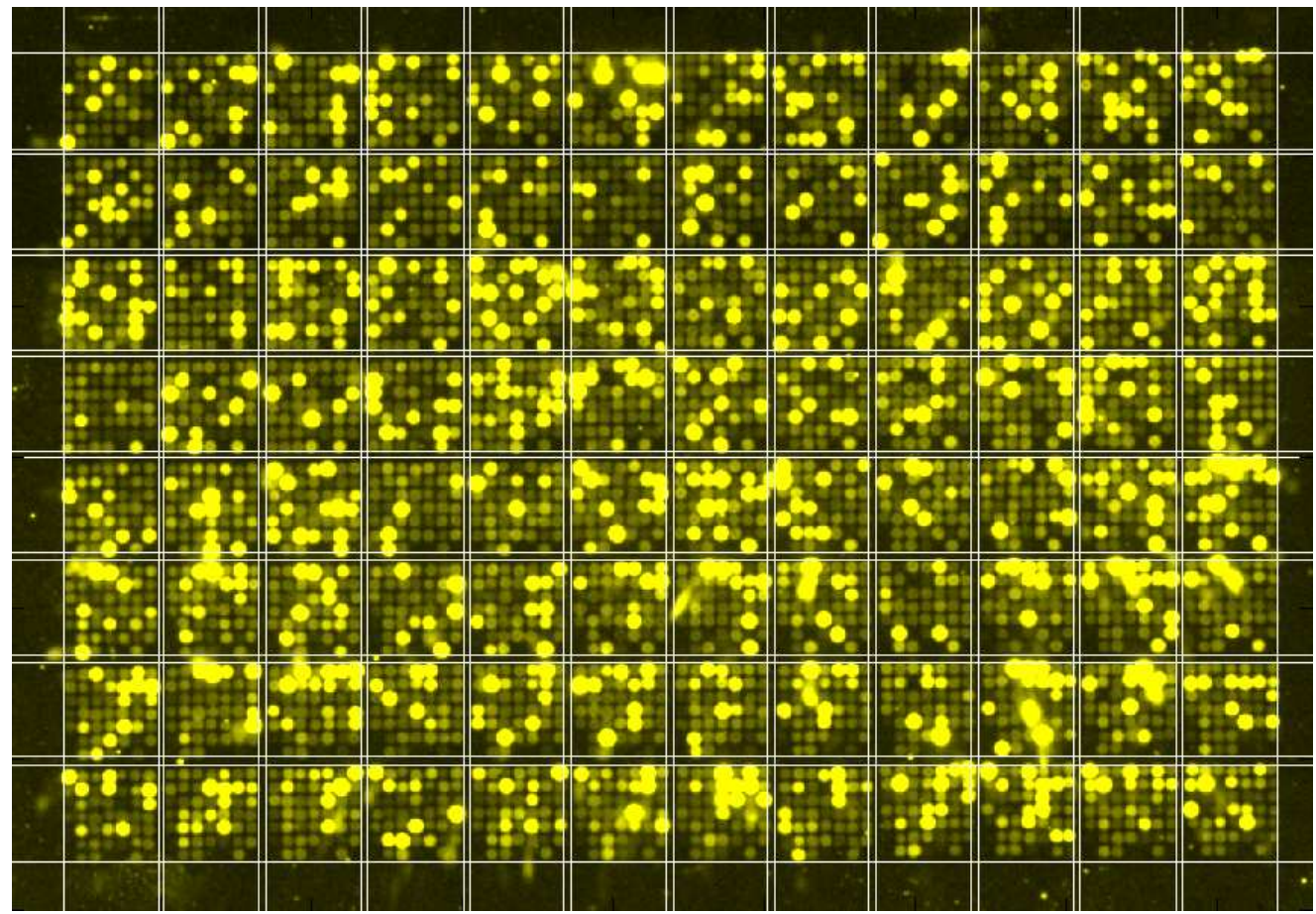

Figura 3.17: Exemplo de gradeamento de membrana (lâmina produzida pela pesquisadora Maria Aparecida Nagai, Departamento de Radiologia, FM-USP).

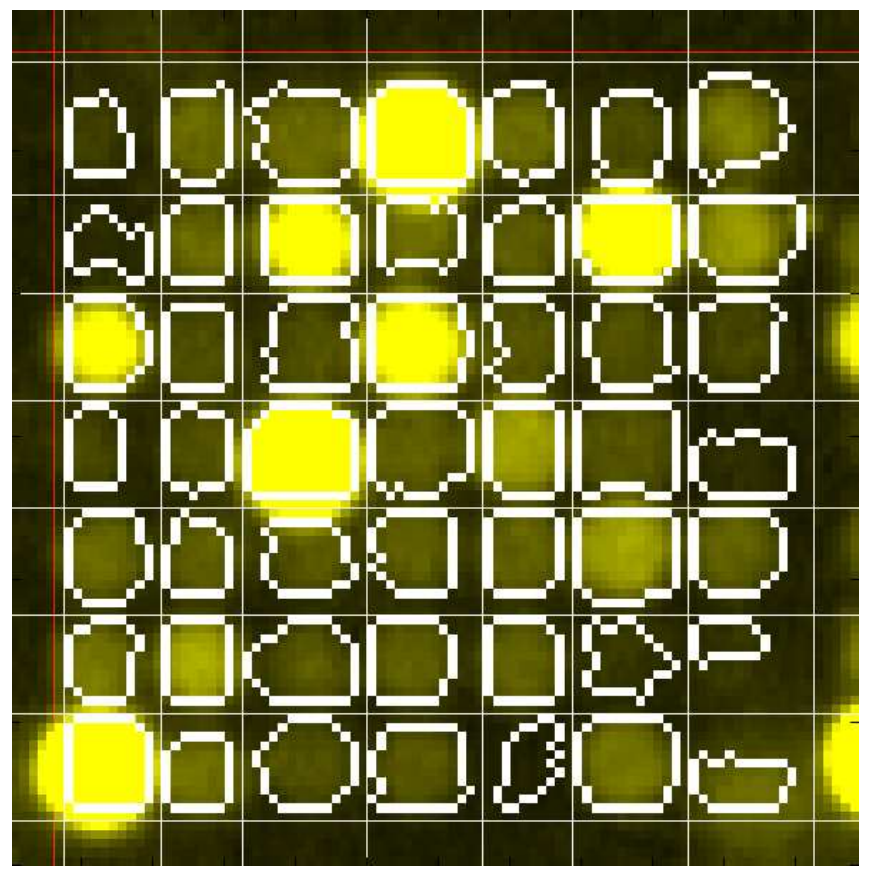

Figura 3.18: Segmentação do primeiro bloco da Figura 3.17 


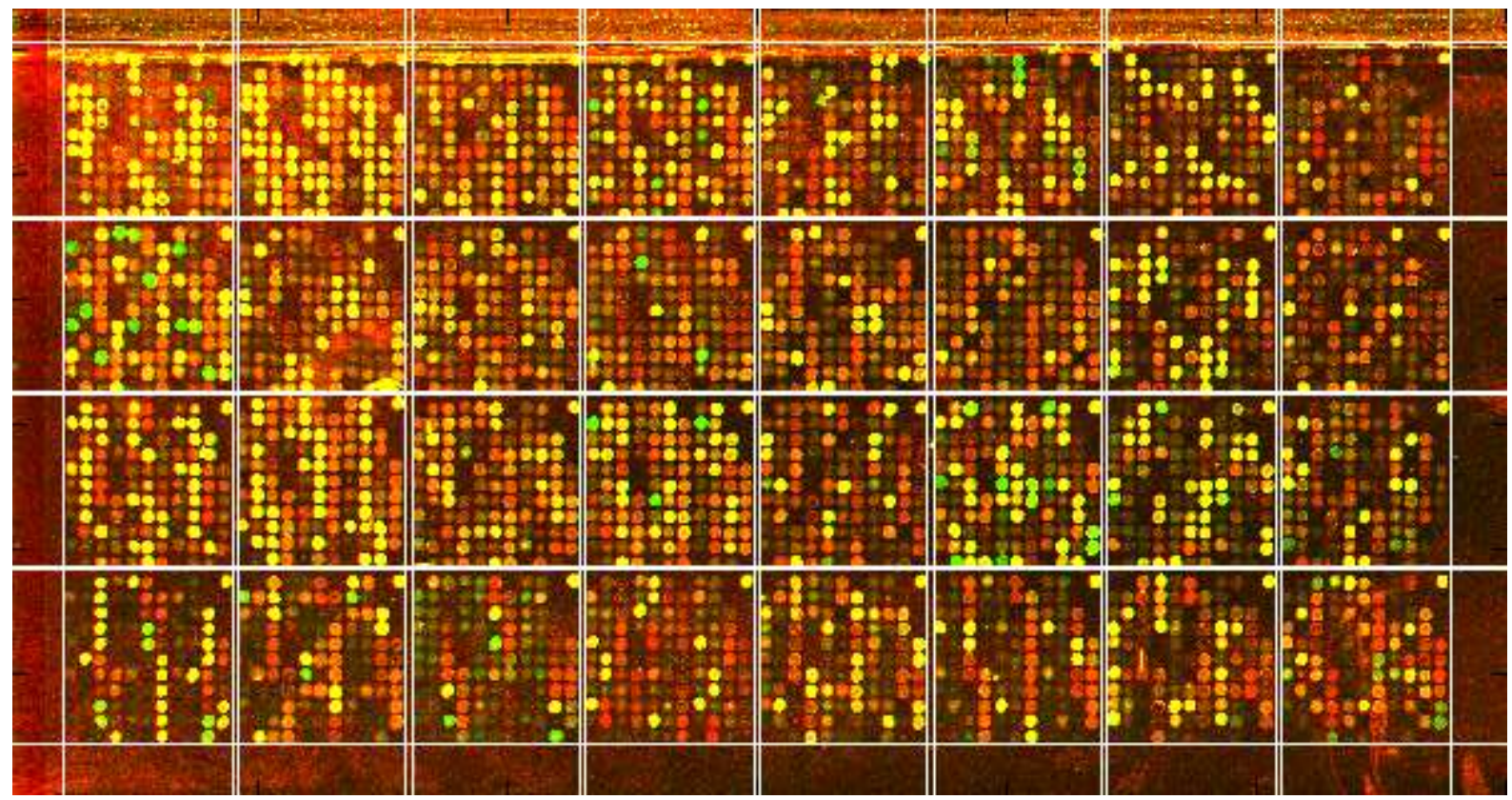

Figura 3.19: Exemplo de gradeamento de lâmina de cDNA de experimento de câncer digitalizada a laser (lâmina produzida pela pesquisadora Helena Paula Brentani, Instituto Ludwig).

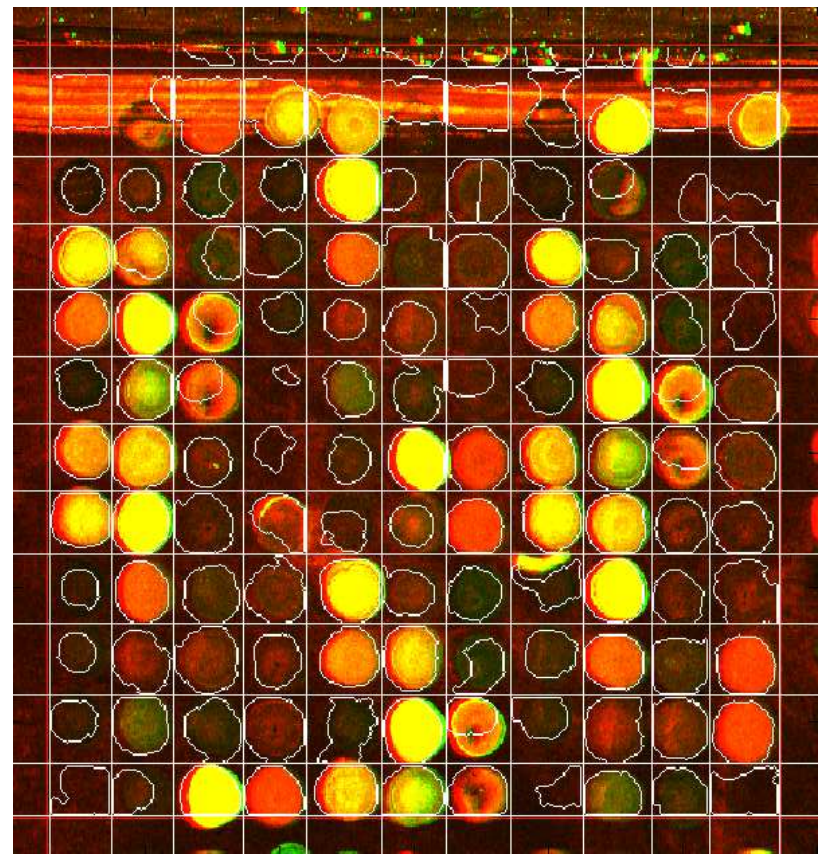

Figura 3.20: Segmentação do primeiro bloco da Figura 3.19 


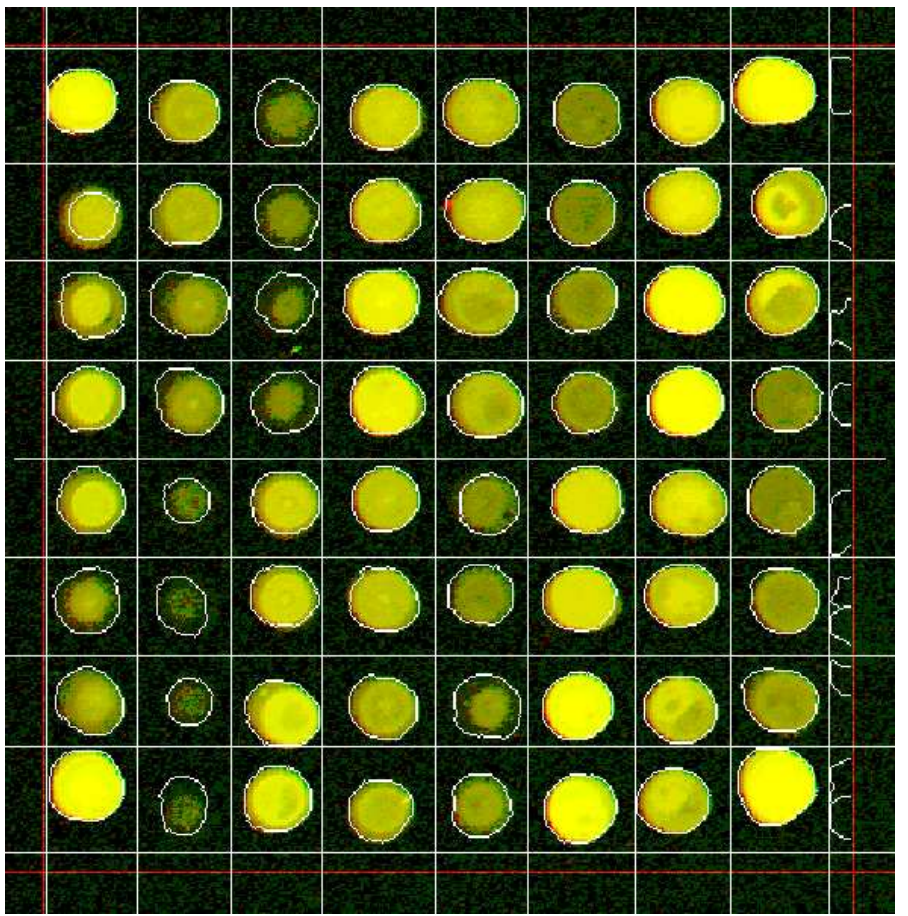

Figura 3.21: Segmentação do primeiro bloco da lâmina de genes sintéticos da Figura 2.3

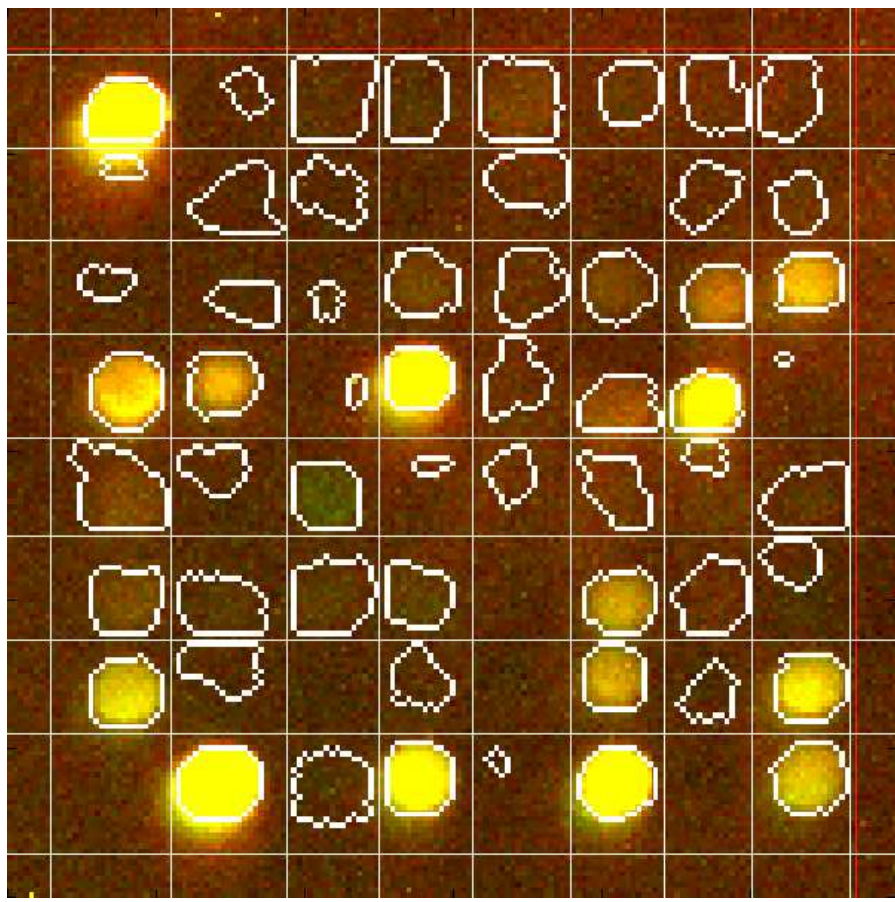

Figura 3.22: Segmentação do bloco da Figura 3.13 


\section{Capítulo 4}

\section{Modelos e medida de expressão}

\section{gênica}

\subsection{Introdução}

Neste Capítulo alguns modelos de expressão gênica, que mostram a relação entre seu valor real e o valor observado na lâmina, são apresentados. Em seguida são mostradas algumas das formas de medida do sinal encontradas na literatura e nas soluções comerciais, e a influência do background no valor do sinal é discutida.

\subsection{Modelos de expressão gênica}

\subsubsection{Modelo linear}

O modelo linear já foi apresentado na Seção 2.4. É um modelo simplificado cuja fórmula, $Y_{i k}=a_{i}+b_{i} X_{i k}$, não apresenta nenhuma variável aleatória que represente o ruído. Na Seção 4.3 são apresentadas várias formas de estimativa de valor do sinal e do background que seguem esse modelo. 


\subsubsection{Modelo de ruído aditivo}

A intensidade média do $k$-ésimo spot ( $\bar{r}_{k}^{m}$ no canal vermelho e $\bar{g}_{k}^{m}$ no canal verde) consiste do sinal fluorescente do cDNA hibridizado na lâmina $\left(\bar{r}_{k}\right.$ e $\left.\bar{g}_{k}\right)$, ruído proveniente de hibridização não específica $\left(\bar{r}_{k}^{b}\right.$ e $\left.\bar{g}_{k}^{b}\right)$ e variações de intensidade $\left(r_{k}^{e}\right.$ e $\left.g_{k}^{e}\right)$, causadas por ruído da etapa de hibridização, digitalização etc:

$$
\begin{aligned}
& \bar{r}_{k}^{m}=\bar{r}_{k}+\bar{r}_{k}^{b} \pm r_{k}^{e} \\
& \bar{g}_{k}^{m}=\bar{g}_{k}+\bar{g}_{k}^{b} \pm r_{k}^{e}
\end{aligned}
$$

A expressão relativa do $k$-ésimo spot é então:

$$
Z_{k}=c \frac{\bar{r}_{k}+\bar{r}_{k}^{b} \pm r_{k}^{e}}{\bar{g}_{k}+\bar{g}_{k}^{b} \pm r_{k}^{e}}
$$

Na maioria dos experimentos de microarray, por exemplo nos que contêm milhares de spots e onde se espera que haja expressão diferencial em poucos genes, podemos assumir que a expressão relativa média $\bar{Z}=1 / n \sum_{k=1}^{n} Z_{k} \approx 1$, onde $n$ é o número de spots na lâmina. Numa lâmina pequena, porém, cujos genes são escolhidos justamente por serem diferencialmente expressos, tal hipótese não vale e genes de controle devem ser usados. Com isso, podemos estimar a variável $c$ usando um método de regressão robusta [7].

\subsubsection{Modelo de ruído exponencial}

Esse modelo permite que intervalos de confiança para a expressão gênica sejam calculados, além de prever dois tipos de ruído. O ruído aditivo, sempre presente e notado especialmente nos spots com valores próximos a zero, é representado por $\epsilon$; e um ruído proporcional ao nível do sinal, representado por $e^{\eta}$, observável especialmente nos spots mais intensos [23].

O modelo é semelhante ao linear, com as componentes do erro inseridas na fórmula: 


$$
Y_{i k}=a_{i}+X_{i k} e^{\eta_{i}}+\epsilon_{i}
$$

onde o índice $k$ representa cada gene e $i$, cada canal. A variável $Y$ é a intensidade observada, $X$ é o nível de expressão em unidades arbitrárias, e $a$ é o background médio, ou seja, média dos genes pouco ou não expressos. Nosso melhor estimador de $X$ é $Y-\hat{a}$, ou seja, a intensidade observada corrigida pela subtração do background.

Note que, nesse modelo, apenas as regiões com spots são consideradas e o background é calculado usando controles negativos ou genes pouco expressos. As regiões externas aos spots são ignoradas.

Assume-se a normalidade dos termos $\epsilon$ e $\eta$ por conveniência, o que é na prática uma suposição razoável. Assim, o ruído aditivo é $\epsilon \sim N\left(0, \sigma_{\epsilon}\right)$, que representa o ruído observado nos genes pouco expressos. O outro termo é $\eta \sim N\left(0, \sigma_{\eta}\right)$, que representa o ruído mais facilmente observável nos spots mais intensos.

Em [14], um modelo equivalente é apresentado, e dados reais são comparados com dados simulados.

Três formas de estimação do background são consideradas e explicadas nas subseções seguintes.

\section{Estimação do background usando controles negativos}

A forma mais fácil de estimar o valor de $a$ médio e de $\sigma_{\epsilon}$ é através de réplicas de controles negativos. O desvio padrão dos controles negativos pode ser usado como estimador de $\sigma_{\epsilon}$, e sua intensidade média como estimador do background médio $a$.

\section{Estimação do background com genes replicados}

Mesmo se tivermos medidas replicadas, sem ter necessariamente controles negativos, podemos estimar a média e desvio padrão do background para cada canal. O algoritmo é iterativo e 
compreende os seguintes passos:

- (i) Comece com um conjunto de genes com baixa intensidade, por exemplo, os $10 \%$ dos genes menos intensos. Calcule a média $\bar{x}_{B}$ de todas as réplicas dos genes escolhidos, e o seu desvio padrão amostral $s_{B}$. Para cada gene no grupo, compute o desvio padrão das réplicas $s_{j}$. Se o número de genes replicados é $m$, calcule

$$
s_{B}=\sqrt{\frac{1}{n-m} \sum_{j=1}^{m} s_{j}^{2}\left(n_{j}-1\right)}
$$

onde $n_{j}$ é o número de réplicas do gene $j$ e $n=\sum_{j=1}^{m} n_{j}$.

- (ii) Defina um novo subconjunto como os genes cujos valores de intensidade estejam no intervalo $\left[\bar{x}_{B}-2 s_{B}, \bar{x}_{B}+2 s_{B}\right]$ e recalcule $\bar{x}_{B}$ e $2 s_{B}$.

- (iii) Repita o passo anterior até que o conjunto de genes não mude.

\section{Estimação do background sem genes replicados}

Caso não haja réplicas dos genes, podemos usar o procedimento abaixo para estimar a média e desvio padrão do background.

- (i) Comece com um conjunto de genes com baixa intensidade, por exemplo, os $10 \%$ dos genes menos intensos. Calcule a média $\bar{x}_{B}$ de suas intensidades, e o seu desvio padrão $s_{B}$.

- (ii) Defina um novo subconjunto como os genes cujos valores de intensidade estejam no intervalo $\left[\bar{x}_{B}-2 s_{B}, \bar{x}_{B}+2 s_{B}\right]$ e recalcule $\bar{x}_{B}$ e $2 s_{B}$.

- (iii) Repita o passo anterior até que o conjunto de genes não mude.

\subsection{Medida da expressão gênica}

Nesta Seção descreveremos algumas das técnicas de estimação da expressão gênica mais usadas pelas soluções disponíveis no mercado. 
A fase de segmentação retorna, para cada spot, uma partição da sua região de interesse, que se divide em sinal e background. O resultado, no entanto, pode variar enormemente dependendo da forma que usamos tal informação, se usamos todos ou apenas alguns dos pixels do sinal, ou se calculamos a expressão relativa pela inclinação da nuvem de pontos formada pelo gráfico dos valores dos pixels em um canal versus o outro canal.

\subsubsection{Histograma}

Este método calcula o histograma dos valores dos pixels na região de interesse do spot e usa quatro parâmetros para quantificar o valor do spot:

- Mínimo do sinal: Menor percentil dos valores dos pixels a ser usado para o cálculo do valor do sinal.

- Máximo do sinal: Maior percentil a ser usado para o cálculo do valor do sinal.

- Mínimo do background: Menor percentil a ser usado para o cálculo do valor do background.

- Máximo do background: Maior percentil a ser usado para o cálculo do valor do background.

Esses dois intervalos são calculados nos dois canais. Os valores do sinal e do background podem ser obtidos pela média, mediana ou moda dos valores dos pixels no intervalo. Como esse método usa a mesma máscara para o sinal e o background, a estimativa pode ser afetada por pixels que tenham intensidade próxima ao do sinal e que não estejam agrupados com este. Esse método é implementado no Quantarray [24].

Observe que, para esse método funcionar, o background deve ser menor que o sinal em todos os spots, o que normalmente não ocorre no caso de genes usados como controles negativos.

\subsubsection{Círculo fixo}

Usa como máscara do sinal um círculo que tem o mesmo tamanho em todos os spots. A máscara do background é escolhida de várias formas. O Quantarray [24] usa uma coroa de círculo circunscrita ao círculo do sinal. O ScanAlyze [25] usa um retângulo circunscrito ao círculo do sinal, sendo excluídos os pixels que fazem parte do sinal dos spots. O CSIRO Spot [26] usa quadrados 
rotacionados de quarenta e cinco graus posicionados no centro de cada quadrado formado pelo centro de quatro spots adjacentes. A Figura 4.1 ilustra as diferentes formas.

Os valores do sinal e background são então obtidos pela média, moda ou mediana dos valores dos pixels na região obtida. Uma variação desse método é a média aparada, que ignora percentis extremos na estimativa do sinal e do background visando eliminar a influência de outlyers.

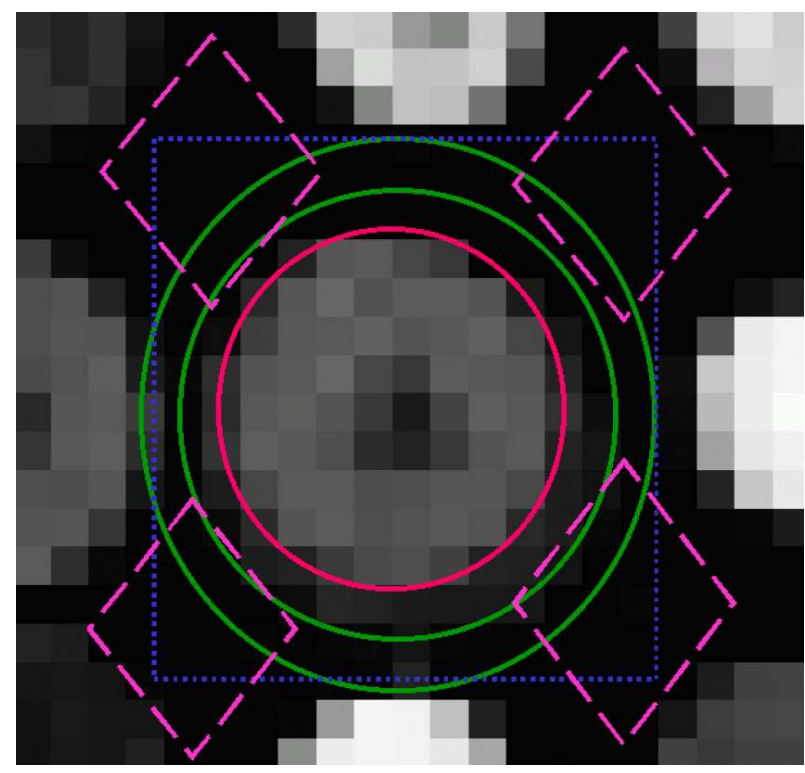

Figura 4.1: Diferentes formas de segmentação do background. A região delimitada pelo círculo mais interno representa o sinal. As outras regiões representam as diferentes formas de delimitar o background: os outros dois círculos em linha cheia são usados pelo Quantarray, o quadrado pontilhado pelo ScanAlyze, e os quatro quadrados tracejados pelo CSIRO Spot [2].

\subsubsection{Adaptativo}

Método implementado no Quantarray, usa a mesma máscara descrita em 4.3.2. Oito pixels do sinal e oito do background são escolhidos e é feito um teste estatístico (Mann-Whitney) que retorna um p-valor que representa a probabilidade de que os pixels das duas amostras pertençam a populações diferentes. O teste é iterado com pixels do sinal cada vez mais brilhantes até que o teste encontre uma diferença significativa entre os pixels do background e do sinal, ou seja, até que um p-valor menor que o definido pelo usuário seja encontrado [27]. 


\subsubsection{Regressão}

Esse método tem a vantagem de não necessitar de uma estimativa do background para encontrar a expressão relativa. Consiste em calcular a reta que melhor ajusta os valores dos pixels de um canal pelo outro. Deve ser usada a regressão robusta, que minimiza a distância entre os pontos e a reta e dá o mesmo valor independentemente da escolha do canal para ser a abcissa ou ordenada. Esse método é implementado no UCSF Spot [28].

\subsubsection{Segmentação morfológica}

Podem-se usar técnicas morfológicas de segmentação para separar o sinal do background. A vantagem sobre o círculo fixo é que este considera pixels do background como sendo do sinal e vice-versa, o que pode adicionar ruído ao valor da expressão.

A abordagem do CSIRO Spot [26] é por crescimento de regiões (seeded region growing). A nossa abordagem é pelo paradigma de Beucher-Meyer, conhecido por watershed.

Em ambos os casos, o sinal e o background podem ser estimados pela média ou mediana. $\mathrm{O}$ nosso programa permite que o usuário escolha os percentis de onde será tirada a estatística.

\subsection{Correção do background}

Uma vez estimado o background, pode-se ou não fazer o ajuste. A forma mais simples e também a mais usada consiste em subtrair o valor do background de cada spot, $b_{k}$, do seu valor de sinal, $f_{k}$. Seja $c_{k}$ o valor do spot $k$ corrigido, $c_{k}=f_{k}-b_{k}$.

Porém, caso o background seja local, isto é, estimado a partir dos pixels da vizinhança do spot, é comum que $c_{k}$ tenha valores negativos, especialmente quando o probe do spot $k$ não tem seu target correspondente na amostra, como é o caso dos controles negativos. Tal fenômeno pode ser evitado utilizando-se outras técnicas de estimativa do background, que levem em conta os controles negativos, ou que não estimem o valor do background acima do valor do sinal para muitos spots, como é o caso dos métodos apresentados na Seção 4.2.3. 
Outro método de correção consiste em, quando um valor de $c_{k}$ for negativo, defini-lo como um inteiro positivo $\delta$ para evitar expressões relativas impossíveis:

$$
c_{k}= \begin{cases}f_{k}-b_{k} & \text { se } f_{k}-b_{k}>\delta \\ \delta & \text { se } f_{k}-b_{k} \leq \delta\end{cases}
$$

É sugerido por Chen et al. [29] usar um valor de $\delta$ igual a 1. Há uma versão mais sofisticada desse método [30] que substitui o $\delta$ do segundo caso por uma função monotônica derivável, linear na escala logarímica em função de $b_{k}$.

$$
c_{k}= \begin{cases}f_{k}-b_{k} & \text { se } f_{k}-b_{k}>\delta \\ \delta \exp \left[1-\left(b_{k}+\delta\right) / f_{k}\right] & \text { se } f_{k}-b_{k} \leq \delta\end{cases}
$$

A idéia por trás dessa fórmula é permitir que spots com expressão muito baixa não sejam considerados todos com o mesmo nível de expressão, $\delta$, e evitar que spots com expressão muito baixa em ambos os canais tenham expressão relativa igual a 1 quando seus níveis de expressão são diferentes, como acontece no método anterior [30].

\subsection{Influência do background no sinal}

No contexto de lâminas de microarray, background se contrapõe a sinal, ou seja, é a parte da lâmina que não possui cDNA impresso e que, portanto, todo sinal é proveniente dos targets que aderiram ao substrato.

Na Seção 4.3 foram descritas várias formas de estimar o background que, supostamente, deve ser subtraído do valor do sinal como forma de eliminar a hibridização não específica. Yang et al. [2] compara os diversos métodos de cálculo do background e os classifica em quatro grupos.

- (1) Background local: o background é estimado para cada spot usando pequenas regiões que o rodeiam. É implementado na grande maioria dos programas no mercado.

- (2) Abertura morfológica: aplica-se uma abertura morfológica em toda a imagem usando 
um elemento estruturante quadrado de lado maior ou igual à distância entre os centros dos spots. O valor do background estimado de um spot é igual ao valor do pixel do seu centro na imagem resultante. Dá uma estimativa menor que a dos outros métodos e não corrompida por pixels mais brilhantes.

- (3) Background constante: método global que subtrai o mesmo valor de background de todos os spots.

- (4) Sem ajuste: a possibilidade de não se fazer nenhuma correção de background também é considerada.

O método do background local tende a ser ruidoso, aumentando o desvio padrão das medidas de razão. O método de background constante teve o mesmo efeito. Já a ausência de ajuste reduz a habilidade de identificar genes diferencialmente expressos. A abertura morfológica é o método dentre os quatro que apresenta o melhor balanço entre variabilidade das medidas e habilidade de identificar genes diferencialmente expressos. Uma estimativa bem sucedida do valor do background deve ter valor maior que zero e menor que o do spot menos intenso da lâmina [2].

Além disso, o método do background local, largamente usado e implementado em diversos programas de análise de imagens, costuma resultar em valores de background maiores que o sinal para uma parcela não desprezível dos spots, e quando a correção é aplicada, tais spots ficam com intensidade negativa, o que sugere que o background deveria ser medido de outra forma.

Quando tais spots são observados cuidadosamente, pode-se notar que a região do sinal tem intensidade menor que o background correspondente, pois mais target adere à região ao redor do spot que ao spot em si. Dessa forma, pode-se concluir que a hibridização não específica dos targets ao substrato segue um modelo diferente da sua hibridização não específica aos probes presentes na lâmina. 


\section{Capítulo 5}

\section{O software desenvolvido}

\subsection{Introdução}

Aqui descreveremos o software desenvolvido para automatizar o processo de segmentação e cálculo da expressão gênica a partir das imagens de microarray.

A maior parte do algoritmo já foi descrito no capítulo 3, sobre a segmentação. Resta descrever a interface com o usuário, e a interface com outros programas ou possíveis módulos que realizem outras partes do processo, ou pipeline [31].

O software foi projetado para que seja um módulo que possa ser conectado com facilidade a outros que façam parte do pipeline. Por isso, além da interface com o usuário, pode ser chamado como parte de um processo de lote e a saída e entrada podem ser feitas através de arquivos de texto com formato padronizado, que podem ser lidos ou criados automaticamente por outros processos.

A interface foi implementada em língua inglesa por ser o protótipo de um produto que visa o mercado internacional.

O arquivo de saída, uma matriz cujos dados são separados por tabulações, pode ainda ser facilmente importado por planilhas eletrônicas ou programas estatísticos. 


\subsection{Interface com o usuário}

O protótipo foi totalmente implementado no $\mathrm{MATLAB}^{\mathrm{TM} 1}$, usando algumas rotinas de morfologia matemática da biblioteca SDC Morphology Toolbox ${ }^{2}$.

Quando usado pela primeira vez, o usuário deve indicar a localização de um par de imagens de microarray, uma para cada canal, e, opcionalmente, um arquivo que tenha os parâmetros da respectiva família de experimentos, de extensão ".glo".

O programa, quando fechado, salva seu estado atual, que inclui o nome dos arquivos das imagens, parâmetros de segmentação e seus resultados, se houver, em um arquivo de experimento, de extensão “.exp”. Reiniciado, este estado é recuperado e o usuário pode continuar o processo do ponto onde parou.

\subsubsection{Interface principal}

A interface principal (Figura 5.1) apresenta a imagem da lâmina em cor falsa, e o resultado da segmentação dos blocos. A interface é simples, procurando ser amigável. Os diversos parâmetros de segmentação, que são calculados a partir das distâncias entre blocos, spots e seu diâmetro esperado, são transparentes ao usuário, que precisa fornecer apenas os parâmetros de geometria da lâmina.

Clicando no botão "Start segmentation", o programa tenta começar a segmentação dos blocos, que consiste em calcular a posição das suas linhas de fronteira com o background. Caso esteja faltando algum parâmetro de geometria, o programa pára e pede ao usuário que insira tal parâmetro.

\footnotetext{
${ }^{1}$ www.mathworks.com

${ }^{2}$ www.mmorph.com
} 


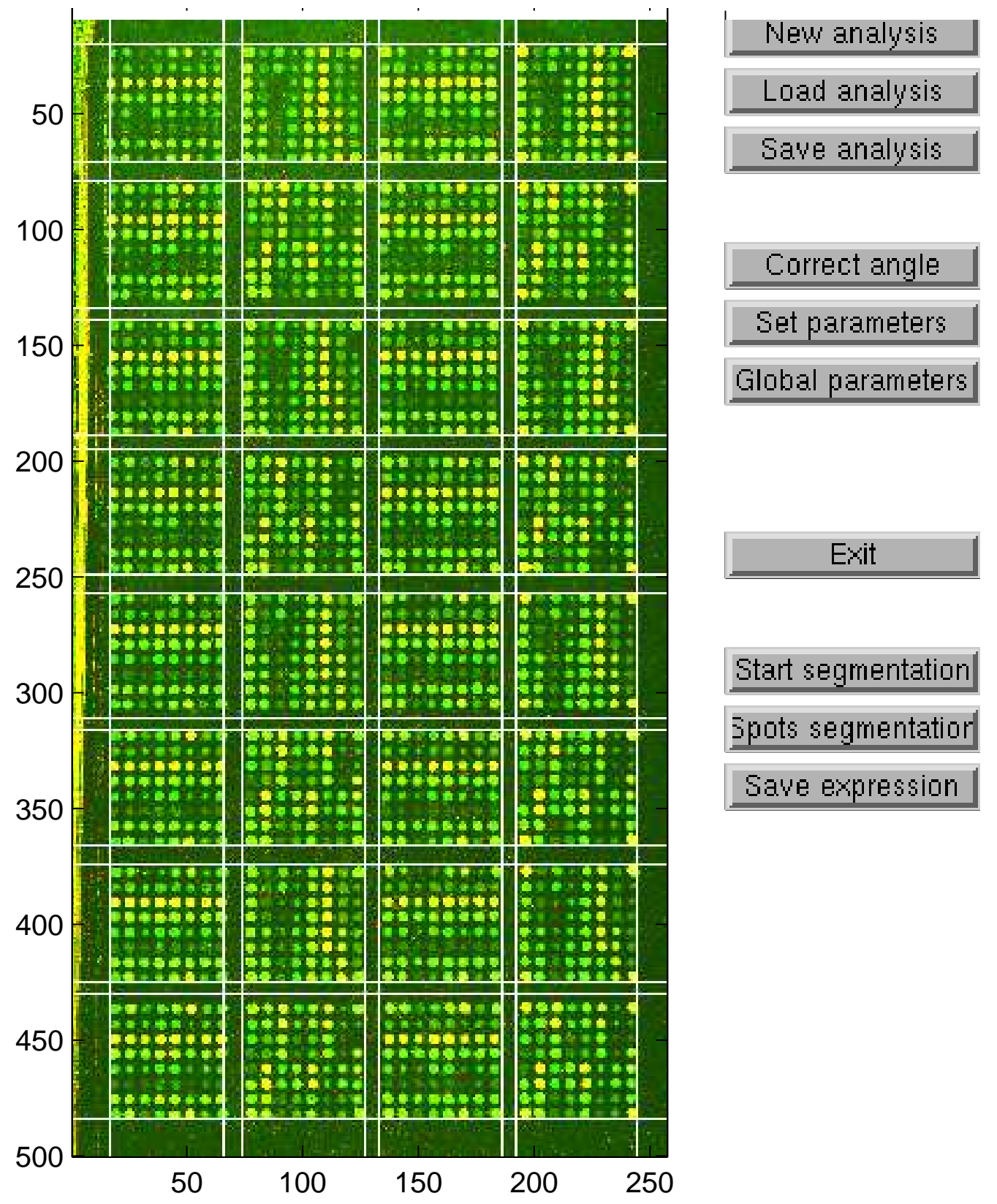

Figura 5.1: Interface principal do programa com a segmentação dos blocos terminada. 
Clicando com o botão direito do mouse sobre a imagem, um pequeno menu é mostrado com algumas opções. Tais opções incluem a inserção ou exclusão de linhas de fronteira dos blocos, mudança do tamanho da janela e acesso à janela de análise individual do bloco.

Terminada a segmentação dos blocos, tendo o usuário feito alguma eventual correção manual na posição de alguma linha mal posicionada, e estando satisfeito com o resultado, pode começar a segmentação dos spots em modo automático clicando em "Spots segmentation". O usuário pode fazer o processo manualmente, bloco a bloco, clicando no bloco com o botão direito e selecionando a opção "Process block". Tal opção também pode ser usada ao final da segmentação automática dos spots se o usuário quiser inspecionar os resultados e recalcular algum bloco que apresente erros.

Por fim, quando toda a segmentação tiver sido completada, um arquivo com os dados de expressão de cada spot pode ser gerado clicando no botão "Save expression". Tal arquivo tem várias colunas com dados de posição do spot na lâmina, a estimativa de sua intensidade e do seu background em cada canal, alguns indicadores de qualidade, e outras medidas, descritas na seção 5.3.

Caso a lâmina não tenha sido digitalizada no mesmo ângulo em que foi impressa, os spots não estarão alinhados paralelamente às bordas da imagem, o que é necessário para a segmentação, já que as linhas das grades, tanto da segmentação dos blocos quanto dos spots, são paralelas. Tal inclinação causa problemas quando a projeção de algum spot está muito próxima ou tem interseção com a projeção de algum spot de outro bloco e os mesmos devem estar separados pela grade dos blocos. Nesse caso, a grade corre o risco de deixar parte do sinal como background e a rotação deve ser corrigida.

Caso isso ocorra, o usuário deve corrigir a rotação através do botão "Correct angle". Aqui o usuário seleciona dois pontos que deveriam estar alinhados e o programa desloca os pixels da imagem, sem alterar seus valores, de modo que os tais pontos se alinhem.

Os botões "Set parameters" e "Global parameters", que serão descritos respectivamente nas seções 5.2.2 e 5.2.3 levam a janelas onde o usuário ajusta parâmetros de visualização e configuração geométrica da lâmina. 
Para analisar uma nova lâmina, o usuário deve clicar no botão "New analysis" e lhe serão pedidos os nomes das imagens e, opcionalmente, o nome de um arquivo ".glo", que contém os respectivos parâmetros de geometria.

O usuário também pode salvar um experimento a qualquer momento em um arquivo de experimento para fazer outras análises e voltar ao primeiro posteriormente. Tais ações estão disponíveis na interface principal através dos botões "Load analysis" e "Save analysis".

\subsubsection{Interface de parâmetros específicos}

Esta janela (Figura 5.2) está disponível através do botão "Set parameters" da interface principal. Através desta janela o usuário pode ajustar alguns parâmetros específicos da lâmina. Pode ativar a equalização de histograma, mudar os pontos de saturação mínimo e máximo ou aumentar o brilho da imagem para que possa visualizar e comparar spots de todas as intensidades. Note que esses ajustes afetam apenas a visualização, não influindo nos valores reais dos pixels ou no resultado.

Aqui o usuário também pode definir uma região de interesse onde se encontram todos os blocos e spots, eliminando manualmente o ruído da borda, ou definir o ângulo de rotação da imagem.

Para maior conveniência do usuário, todas as alterações são descartadas caso se pressione o botão "Cancel". Pressionando "Ok" as alterações são salvas e retorna-se à janela principal. 


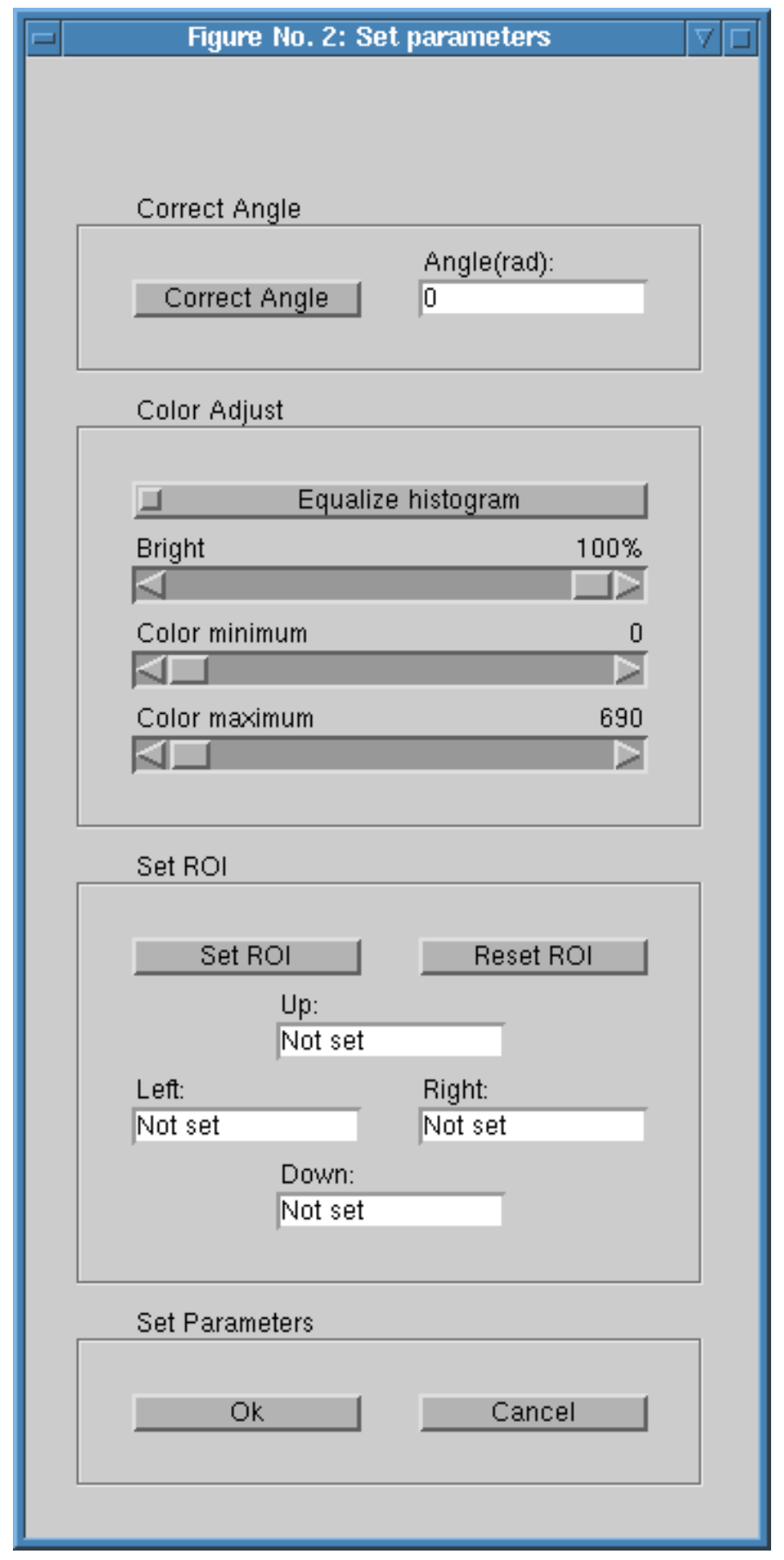

Figura 5.2: Interface de parâmetros específicos da lâmina. 


\subsubsection{Interface de parâmetros globais}

Esta janela (Figura 5.3) aparece ao se pressionar o botão "Global parameters" da interface principal. Nesta o usuário define os parâmetros geométricos da lâmina. São os nove parâmetros necessários para segmentar a lâmina automaticamente: distâncias horizontal e vertical entre os blocos, distâncias horizontal e vertical entre os spots, número de linhas e colunas de blocos, número de linhas e colunas de spots por bloco e diâmetro aproximado do spot.

Ao pressionar o botão "Output options", uma pequena caixa de diálogo aparece para que o usuário defina os parâmetros de cálculo da expressão dos métodos do histograma e da região fixa. Tais parâmetros são os percentis que serão considerados para a estimação do sinal e do background. Para a definição dos percentis, os valores dos pixels podem ser ordenados de duas formas, independentemente nos dois canais, ou segundo o valor da distância city-block até a origem.

Para maior conveniência do usuário, todas as alterações são descartadas caso se pressione o botão "Cancel". Pressionando "Ok" as alterações são salvas e retorna-se à janela principal.

Nesta janela, o usuário também pode gravar os parâmetros em um arquivo ".glo" para uso posterior em outras lâminas do mesmo lote de experimentos. A gravação é feita pelo botão "Save" e o carregamento, pelo botão "Load". 


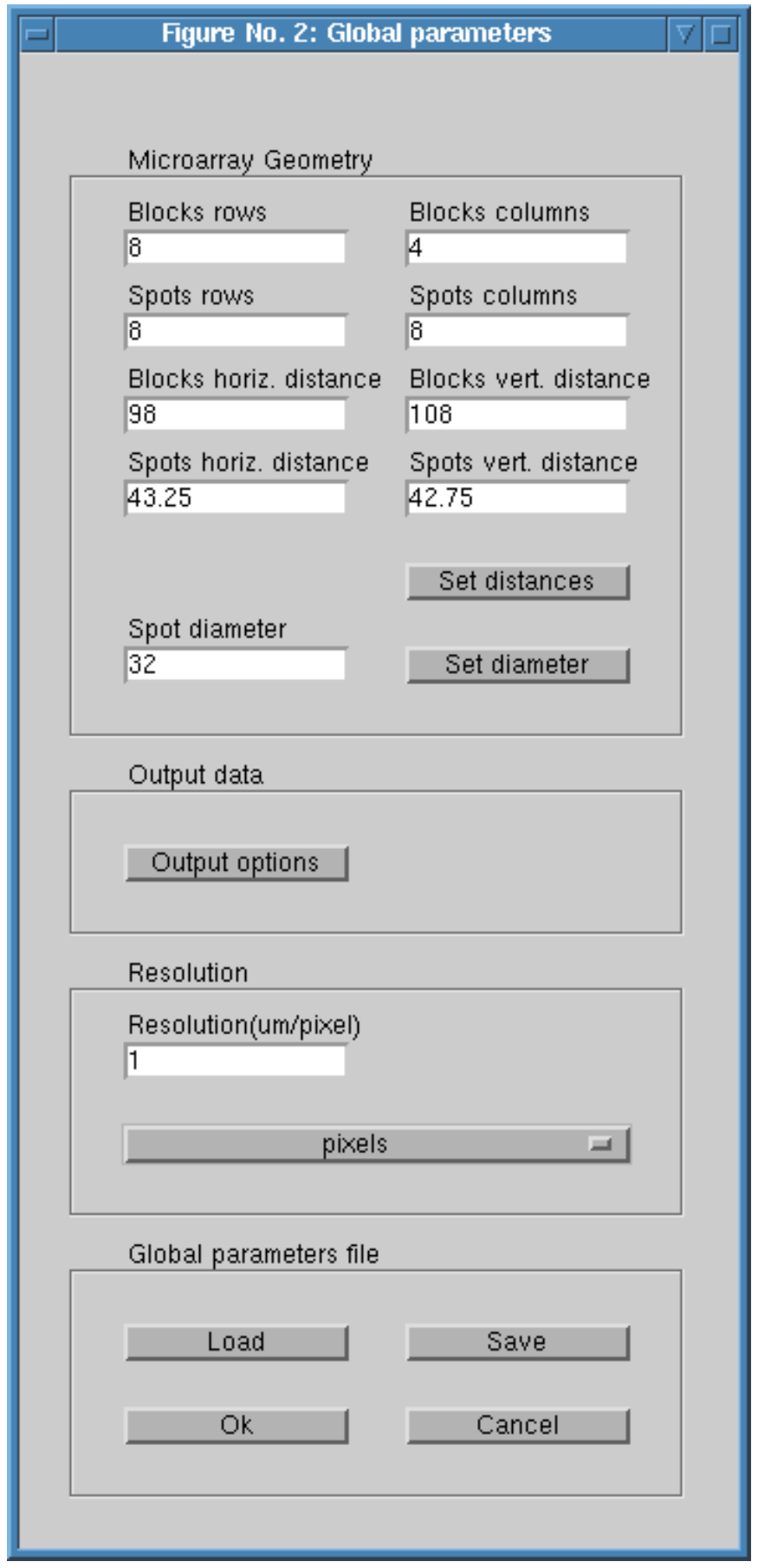

Figura 5.3: Interface de parâmetros globais da família de experimentos. 


\subsubsection{Interface de análise do bloco}

Esta interface (Figura 5.4) é mostrada quando o usuário clica em algum bloco na interface principal e seleciona a opção "Process block" do menu. Como na interface principal, o usuário também tem acesso a um pequeno menu quando clica com o botão direito na imagem. Neste menu são apresentadas as opções de incluir ou excluir linhas da grade, marcar ou desmarcar algum spot, por estar ruim ou por merecer atenção especial, com um flag bit, analisar algum spot (opção "Process spot") ou mudar o tamanho da imagem na tela.

No arquivo de dados de saída, os spots marcados com o flag bit possuem valor diferente de zero na coluna apropriada.

Selecionando a opção "Process spot", alguns gráficos e valores são apresentados para o usuário em seqüência. Primeiro um scatter plot dos valores dos pixels de um canal pelo outro é mostrado, onde pontos que representam pixels do background aparecem com cor diferente dos pontos do sinal. Ao mesmo tempo, aparecem os valores de correlação, e as derivadas de uma regressão e de um ajuste robusto (robust fit). O segundo gráfico mostra quatro curvas: para os canais verde e vermelho, mostra as curvas dos valores dos pixels, do sinal e de toda a região de interesse ou ROI (region of interest) do spot (sinal junto do background), depois de ordenados. O terceiro gráfico mostra duas curvas: uma é o quociente entre os valores dos pixels do sinal ordenados de um canal pelo outro; a outra é o quociente entre as curvas dos pixels da ROI do spot. O quarto gráfico é um histograma do logaritmo na base dois dos quocientes entre pixels de um canal pelo outro. As barras que representam pontos do sinal estão com cor diferente das que representam pontos do background.

Nesta interface o usuário também pode ajustar os parâmetros de visualização de saturação mínima, máxima e equalização de histograma. São úteis para verificar se as bordas de spots muito apagados estão coerentes com a borda detectada.

O botão "Grid \& segment" inicia o processo de gradeamento e segmentação dos spots. No final do processo, caso haja alguma linha de grade mal posicionada, o usuário pode corrigi-la clicando na imagem e pressionar o botão "Segment only", que mantém a grade definida pelo usuário e calcula apenas a segmentação dos spots. 
O gradeamento e segmentação efetuados nesta janela são salvos automaticamente.

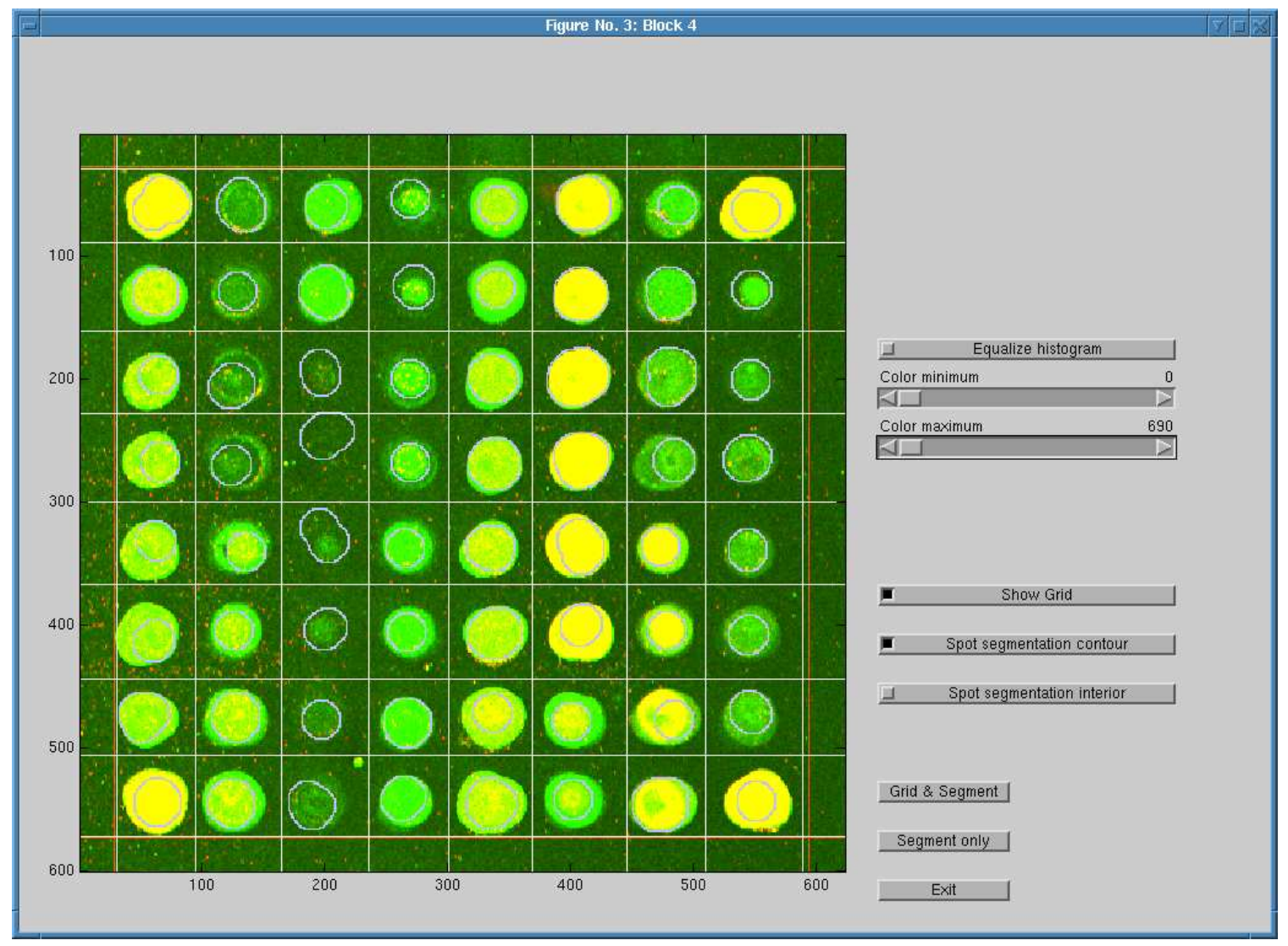

Figura 5.4: Interface para análise de blocos individuais.

\subsubsection{Correção de rotação}

Para que o gradeamento seja bem sucedido, os spots devem estar alinhados paralelamente às bordas da imagem. Caso isso não ocorra, os perfis horizontal e vertical não terão um bom contraste, o que dificulta o gradeamento. Além disso, a partir de um certo ângulo de rotação, spots de uma coluna de blocos podem estar alinhados verticalmente com spots de outra coluna de blocos, e nesse caso, como as linhas de grade são retas paralelas à borda da imagem, uma separação perfeita das colunas de blocos se torna impossível.

O método proposto para correção de rotação depende do usuário. Pode corrigir pequenos ângulos e é feito por uma interface onde o usuário escolhe dois pontos da imagem que deveriam 


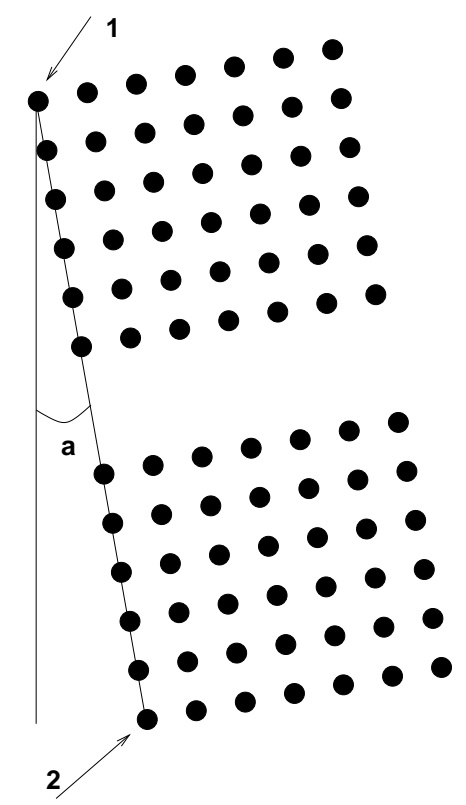

Figura 5.5: O usuário seleciona dois pontos para definir o ângulo de rotação.

estar verticalmente alinhados, definindo o ângulo de rotação. A Figura 5.5 ilustra o processo de escolha dos pontos, por exemplo, o centro do spot no extremo superior esquerdo e o centro do spot inferior esquerdo.

O programa calcula o ângulo $a$ e corrige a posição dos pixels $p=(x, y), \forall p \in E$, onde $E$ é a imagem, transladando-o verticalmente do inteiro mais próximo a $\tan (a)\left(x-x_{0}\right)$ e horizontalmente do inteiro mais próximo a $\tan (a)\left(y-y_{0}\right)$, onde $\left(x_{0}, y_{0}\right)$ é o centro da imagem.

É importante notar que não podemos aplicar métodos de rotação convencionais (linear, bilinear, bicúbico etc) pois estes alteram o valor dos pixels. Nosso método é equivalente a utilizar linhas de grade que formam um ângulo $a$ com as bordas da imagem.

Parte das bordas da imagem é perdida no processo de rotação, o que não é problema se nessa região não houver sinal, ou seja, spots. 


\subsection{Arquivo de saída}

$\mathrm{O}$ arquivo de saída é um arquivo de texto que pode ser aberto em qualquer editor de texto ou programa estatístico. Em cada linha estão todas as informações do respectivo spot e as colunas são separadas por tabulações. O formato do arquivo é igual ao do ScanAlyze [25], com algumas colunas a mais e outras a menos.

A primeira coluna pode apresentar três valores: "HEADER" se a linha contém os nomes das colunas, "REMARK" se a linha contiver algum comentário, ou "SPOT" se a linha for referente a algum spot.

Na saída do programa, a primeira linha é do tipo "HEADER", que mostra o nome das colunas de dados que aparecem nas linhas do tipo "SPOT". Em seguida vêm as linhas "REMARK", cuja segunda coluna apresenta os seguintes valores: "SOFTWARE" com o nome do programa que gerou o arquivo, "SOFTVERS" com a versão do programa, "GLO FILE" com o nome do arquivo ".glo" se houver, "CH1 IMAGE" e "CH2 IMAGE" com os nomes das imagens verde e vermelha respectivamente, e "DATE" e "TIME" com a data e hora de geração do arquivo.

Finalmente temos as linhas do tipo "SPOT", com tantas colunas quanto a linha "HEADER". Atualmente, as colunas gravadas no arquivo de saída são as seguintes:

- SPOT (inteiro): é um índice único para cada spot. Começa com 1 (um) e aumenta de um para cada novo spot processado. Os spots são processados em uma ordem bem definida e a partir de tal índice pode-se encontrar o bloco e a posição do spot dentro dele. Todos os spots de cada linha são processados, da esquerda para a direita, antes de passar para a linha seguinte, imediatamente abaixo.

- GRID (inteiro): é um índice único para cada bloco. Começa com 1 (um) e aumenta de um para cada novo bloco processado. Os blocos são processados em uma ordem bem definida e todos seus spots são processados antes de se começar outro bloco. Todos os blocos de cada linha são processados, da esquerda para a direita, antes de se passar para a linha seguinte, imediatamente abaixo.

- TOP (inteiro): a ROI de cada spot é um pequeno retângulo que o contém. Para defini-lo bastam quatro valores numéricos da posição das linhas que o limitam: limites superior, 
inferior, direito e esquerdo. O valor desta coluna é a posição do limite superior da ROI do spot na imagem.

- LEFT (inteiro): a posição do limite esquerdo da ROI do spot na imagem.

- BOT (inteiro): a posição do limite inferior da ROI do spot na imagem.

- RIGHT (inteiro): a posição do limite direito da ROI do spot na imagem.

- ROW (inteiro): linha em que se localiza o spot no respectivo bloco. A linha do extremo superior tem valor igual a 1 (um) e cresce de um para cada nova linha processada.

- COL (inteiro): coluna em que se localiza o spot no respectivo bloco. A coluna da extrema esquerda tem valor igual a $1(\mathrm{um})$ e cresce de um para cada nova coluna processada.

- $\mathrm{CH} 1 \mathrm{I}$ (inteiro): valor médio arredondado dos pixels do sinal no canal verde.

- CH1B (inteiro): valor mediano arredondado dos pixels do background no canal verde.

- $\mathrm{CH} 1 \mathrm{AB}$ (inteiro): valor médio arredondado dos pixels do background no canal verde.

- CH2I (inteiro): valor médio arredondado dos pixels do sinal no canal vermelho.

- CH2B (inteiro): valor mediano arredondado dos pixels do background no canal vermelho.

- $\mathrm{CH} 2 \mathrm{AB}$ (inteiro): valor médio arredondado dos pixels do background no canal vermelho.

- SPIX (inteiro): número de pixels do sinal.

- BGPIX (inteiro): número de pixels do background, que é o complementar do sinal na ROI do spot.

- MRAT (inteiro): contém a mediana de

$$
\frac{\mathrm{CH} 2 \mathrm{PI}-\mathrm{CH} 2 \mathrm{~B}}{\mathrm{CH} 1 \mathrm{PI}-\mathrm{CH} 1 \mathrm{~B}}
$$

onde CH1PI e CH2PI representam valores de pixels isolados do sinal.

- REGR (real): contém a derivada da reta ajustada aos valores dos pixels por mínimos quadrados.

- CORR (real): coeficiente de correlação entre os valores dos pixels. O que aparece como uma nuvem circular no scatter plot apresenta correlação próxima de zero, e uma nuvem alongada apresenta correlação próxima de um.

- CH1GTB1 e CH2GTB1 (percentual): fração dos pixels do sinal maiores que CH1B e CH2B respectivamente. 
- CH1GTB2 (percentual): fração dos pixels do sinal do sinal maiores que 1.5 vezes CH1B e $\mathrm{CH} 2 \mathrm{~B}$ respectivamente.

- CH1EDGEA e CH2EDGEA (real): valor médio dos vetores de Sobel vertical e horizontal no interior do spot nos canais 1 e 2 .

- FLAG (binário): igual a um somente se o respectivo spot for marcado pelo usuário.

- CH1KSD, CH1KSP, CH2KSD e CH2KSP: comparam as distribuições dos valores dos pixels do sinal com os do background. Os valores CH1KSD e CH2KSD são os valores da estatística de Kolmogorov-Smirnov, e CH1KSP e CH2KSP são as probabilidades de que os pixels do sinal têm a mesma distribuição do background.

- $\mathrm{CH} 1 \mathrm{ABB}$ e CH2ABB (inteiro): valor arredondado da média dos valores dos pixels no retângulo que limita todo o bloco. Não se mostrou uma boa aproximação do valor do background.

- $\mathrm{CH} 1 \mathrm{AB} 10$ e CH2AB10 (inteiro): valor arredondado da média dos valores dos pixels do primeiro decil na ROI do spot.

- CH1B10 e CH2B10 (inteiro): valor arredondado da mediana dos valores dos pixels do primeiro decil na ROI do spot.

- CH1AF10 e CH2AF10 (inteiro): valor arredondado da média dos valores dos pixels do último decil na ROI do spot.

- CH1F10 e CH2F10 (inteiro): valor arredondado da mediana dos valores dos pixels do último decil na ROI do spot.

- CH1ERO e CH2ERO (inteiro): valor arredondado da média dos valores dos pixels da região do sinal erodida por um elemento estruturante circular com um sexto do diâmetro esperado do spot.

- CH1FHIST_80_95 e CH2FHIST_80_95 (inteiro): valor arredondado da média dos valores dos pixels na ROI do spot entre os percentis indicados no nome da coluna. Tais percentis são escolhidos pelo usuário na janela "Global parameters", pressionando o botão "Output parameters". O sinal se distingue do background apenas pelo valor maior dos percentis, já que a região considerada é a mesma.

- CH1BHIST_5_20 e CH2BHIST_5_20 (inteiro): valor arredondado da média dos valores dos pixels na ROI do spot entre os percentis indicados no nome da coluna. Tais percentis 
são escolhidos pelo usuário na janela "Global parameters", pressionando o botão "Output parameters".

- CH1FFIXR_45_95 e CH2FFIXR_45_95 (inteiro): valor arredondado da média dos valores dos pixels do sinal do spot entre os percentis indicados no nome da coluna. Tais percentis são escolhidos pelo usuário na janela "Global parameters", pressionando o botão "Output parameters".

- CH1BFIXR_5_55 e CH2BFIXR_5_55 (inteiro): valor arredondado da média dos valores dos pixels do background do spot entre os percentis indicados no nome da coluna. Tais percentis são escolhidos pelo usuário na janela "Global parameters", pressionando o botão "Output parameters".

\subsection{Próximos passos}

Numa versão definitiva, a interface principal deve também apresentar a segmentação dos spots. Deve ainda ser implementada num ambiente que ofereça mais recursos de interface, já que o MATLAB $^{\mathrm{TM}}$ é bastante limitado. Por exemplo, o usuário não precisaria clicar na imagem e indicar um tamanho, mas o faria clicando e arrastando os cantos da janela.

O programa, na sua versão atual, já apresenta um protótipo de correção de rotação automática, e a versão final deverá ter uma versão melhorada deste procedimento. 


\section{Capítulo 6}

\section{Validação}

Existem diversos métodos para estimação da expressão gênica, sendo que os principais foram apresentados no Capítulo 4. Em sua dissertação de mestrado, Gustavo H. Esteves [32], do Instituto Ludwig de Pesquisa contra o Câncer, compara as diversas técnicas propostas por meio de experimentos controlados projetados para tal.

O primeiro experimento, denominado exp1/1, foi feito sem swap, e a razão esperada entre as amostras teste e referência foi igual a um. No entanto, tal exprimento não permite que as técnicas de medida sejam comparadas para genes diferencialmente expressos. Para contornar esse problema, o experimento foi refeito, agora com swap e com quantidades diferentes de cDNA marcado, apresentando razões esperadas de três e seis. Os experimentos foram denominados $\exp 3 / 1$ e $\exp 6 / 1$ respectivamente.

Tais experimentos permitem que se faça a normalização por swap, mas não permitem que se verifique a corretude dos valores encontrados por não ter genes com a mesma razão esperada, os genes de housekeeping. Por essa razão, projetamos novos experimentos que contivessem tanto genes com razão 1 (um) quanto genes diferencialmente expressos. Foram feitos mais três experimentos onde os genes diferencialmente expressos tinham razões cinco, dois e dez, denominados respectivamente $\exp 1 / 1-1 / 5, \exp 1 / 1-1 / 2$ e exp1/1-1/10, todos com swap.

Para estimar o erro, comparou-se a razão obtida nos experimentos com a razão esperada usando a função 


$$
E=\frac{\sum_{i=1}^{p}\left|r_{i}-r_{e}\right|}{p}
$$

onde $p$ é o número de spots de um dado gene, $r_{i}$ é a razão observada em cada spot e $r_{e}$ é a razão esperada.

As expressões foram medidas pelas técnicas:

- Circfix: Segmentação por círculo fixo, descrita em 4.3.2. Tem a desvantagem de não separar bem o sinal do background, o que pode resultar em superestimação do background, especialmente nos spots mais intensos, ou acréscimo de ruído aos valores de expressão. Foi a metodologia adotada que incorreu em maiores erros nos genes mais expressos (genes $3,5$ e 6$)$ de $\exp 1 / 6$ e de $\exp 1 / 3$. Nos três últimos experimentos, $\exp 1 / 1-1 / 5, \exp 1 / 1$ 1/2 e exp1/1-1/10, também apresentou comportamento semelhante a Segment-100-100, mostrando um erro médio menor nos genes diferencialmente expressos (genes 1, 3 e 5) e erro médio maior nos genes menos expressos e com razão igual a um (genes 2 e 4).

- Adap: Segmentação adaptativa, descrita em 4.3.3. Foi a técnica que apresentou em exp1/1 um índice de dispersão muito maior que as outras técnicas nos genes pouco expressos, apesar de se mostrar um pouco menor nos outros genes. Esse alto índice de dispersão aparece também em outros experimentos e pode ser observado pelos gráficos. Na Figura 6.3 pode-se ver que os maiores erros nos genes menos expressos (genes 1, 2 e 4) são cometidos por esta metodologia em cinco dos seis casos. Esta metodologia também apresentou erros maiores em exp1/1-1/10, nos genes onde a razão esperada entre teste e referência era igual a dez (genes 1,3 e 5).

- Circhist-50-50: Variação da metodologia de segmentação por círculo fixo, descrita em 4.3.2, eliminando-se alguns percentis. Aqui os pixels usados estão entre os percentis 45 e 95 da distribuição do sinal e entre os percentis 5 e 55 da distribuição do background. Os pixels usados podem ser diferentes nos dois canais.

- Circhist-100-20: Variação da metodologia de segmentação por círculo fixo, descrita em 4.3.2, eliminando-se alguns percentis. Aqui usam-se todos os pixels do sinal e os que estejam en- 
tre os percentis 1 e 20 da distribuição do background. Os pixels usados podem ser diferentes nos dois canais.

- Circhist-30-10: Variação da metodologia de segmentação por círculo fixo, descrita em 4.3.2, eliminando-se alguns percentis. Aqui os pixels usados são os $30 \%$ mais intensos do sinal e os $10 \%$ menos intensos do background. Faz-se um único histograma e os pixels usados são os mesmos nos dois canais.

- Hist-15-15: Método descrito em 4.3.1. Os pixels usados para estimar o sinal estão entre os percentis 80 e 95 e para o background, entre 5 e 20 .

- Segment-50-50: Metodologia de segmentação morfológica, descrita em 4.3.5, usando os mesmos percentis de Circhist-50-50.

- Segment-100-20: Metodologia de segmentação morfológica, descrita em 4.3.5, usando os mesmos percentis de Circhist-100-20.

- Segment-100-100: Metodologia de segmentação morfológica, descrita em 4.3.5, usando todos os percentis do sinal e do background. Mostra um comportamento semelhante ao de Circfix, nos três últimos experimentos, e em exp1/3, apesar de ser o melhor em cinco dos seis genes de $\exp 1 / 6$.

As metodologias Circhist-50-50, Circhist-100-20, Circhist-30-10, Hist-15-15, Segment-50-50 e Segment-100-20 apresentaram erros semelhantes em todos os experimentos e respectivos genes. 


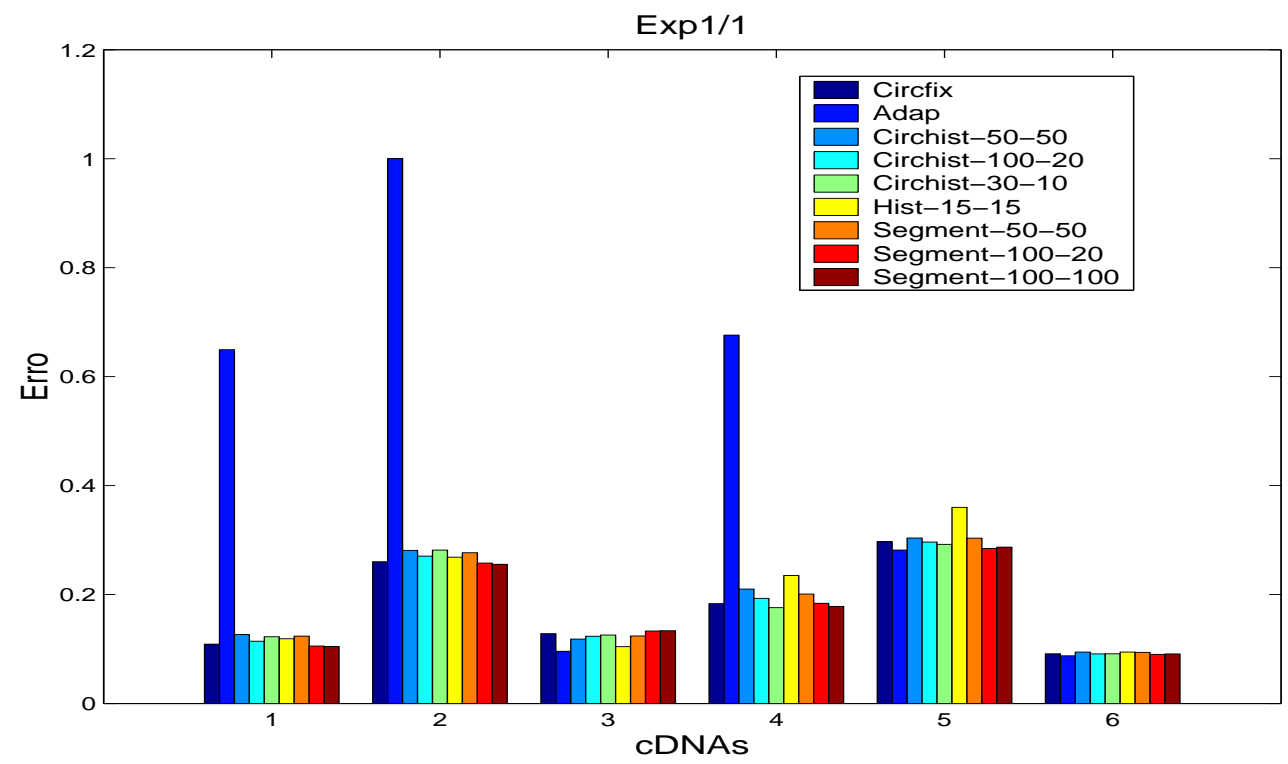

Figura 6.1: Erros cometidos no experimento exp1/1 (com diluição 5). Erros cometidos pelas diferentes metodologias empregadas para a quantificação dos experimentos. Nesta figura são mostrados os erros cometidos para spots de todos os cDNAs utilizados com diluição cinco no experimento exp1/1. Os cDNAs estão indicados no eixo $x$ na seguinte ordem: 1 - LysA, 2 - TrpC, 3 - Gene Q, 4 - ST0280, 5 - Il-6, 6 - Irf-1.

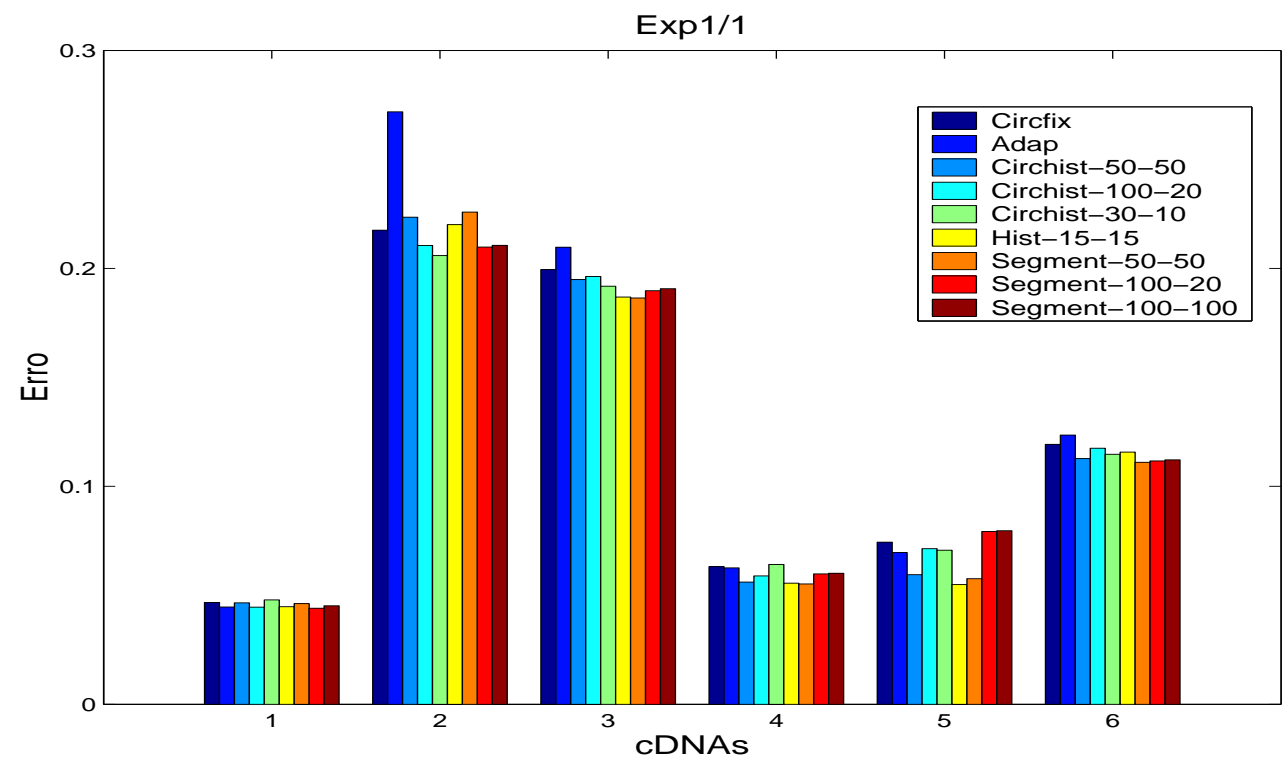

Figura 6.2: Erros cometidos no experimento exp1/1.

Esta figura ilustra os erros cometidos pelas diferentes metodologias de quantificação para o experimento exp1/1. Os cDNAs estão indicados no eixo $x$ na seguinte ordem: 1 - LysA, 2 - TrpC, 3 - Gene Q, 4 - ST0280, 5 - Il-6, 6 - Irf-1. 


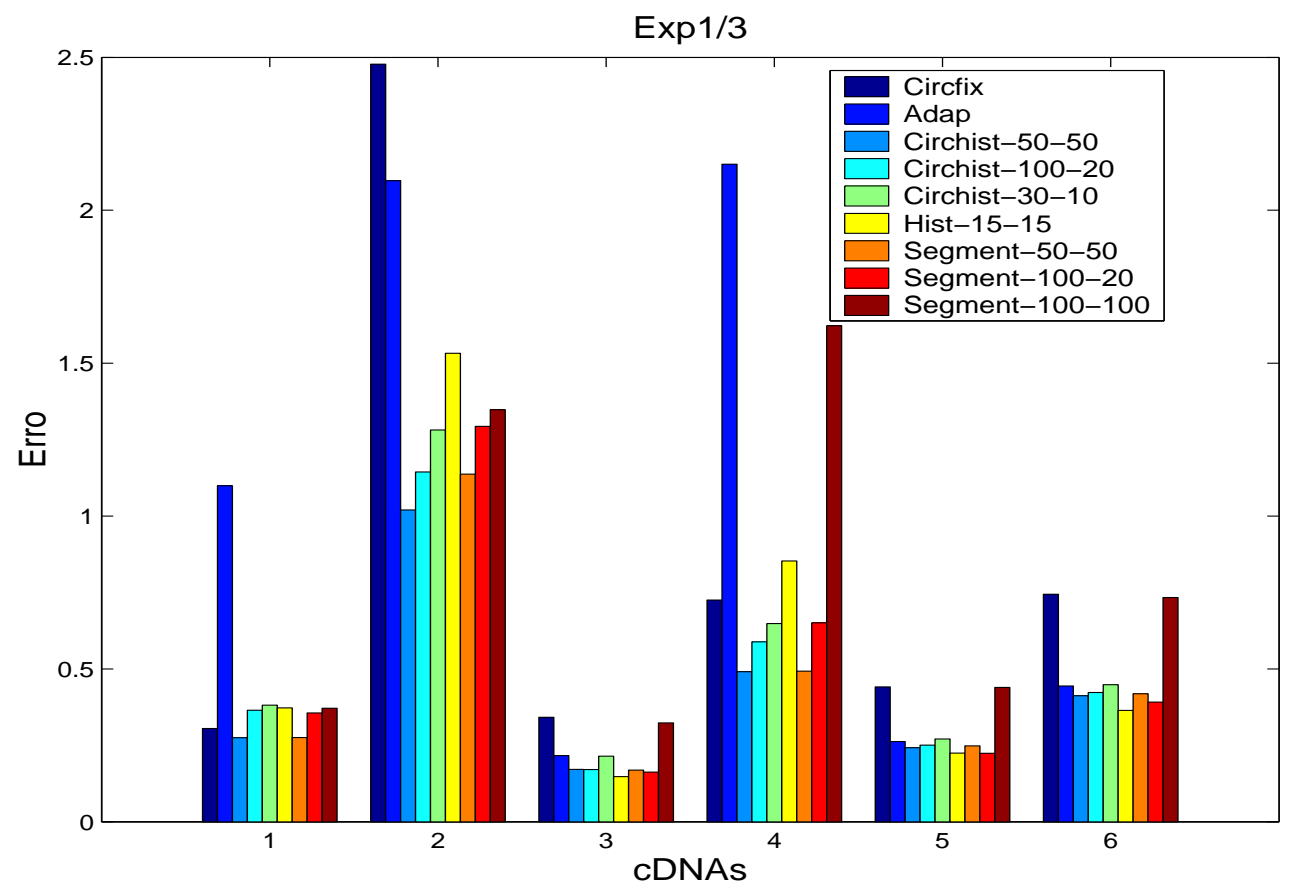

(A)

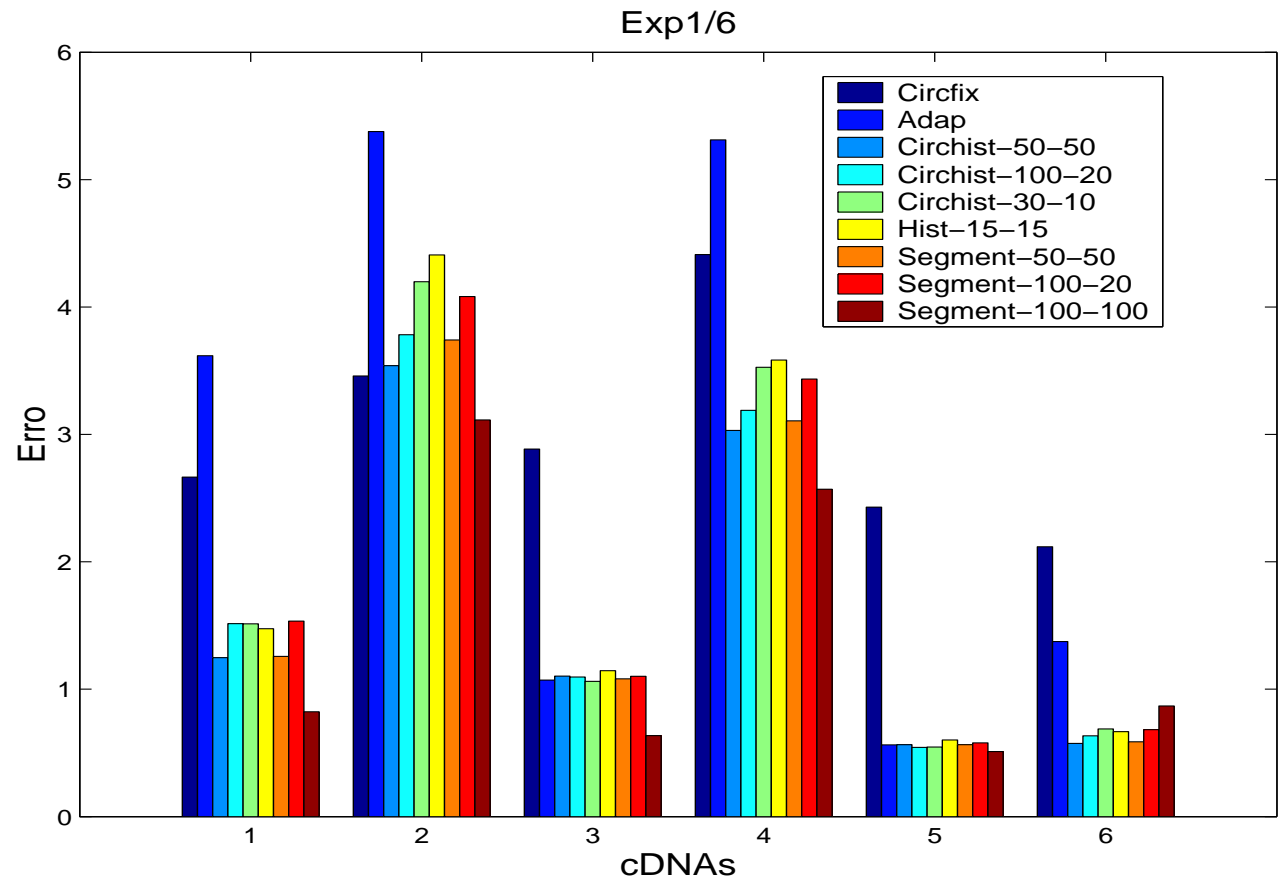

(B)

Figura 6.3: Erros cometidos nos experimentos exp3/1 e exp6/1.

Erros cometidos pelas diferentes metodologias empregadas para a quantificação dos experimentos (A) - exp3/1 e (B) - exp6/1. Os cDNAs estão indicados no eixo $x$ na seguinte ordem: 1 - LysA, 2 - TrpC, 3 - Gene Q, 4 - ST0280, 5 - Il-6, 6 - Irf-1. 


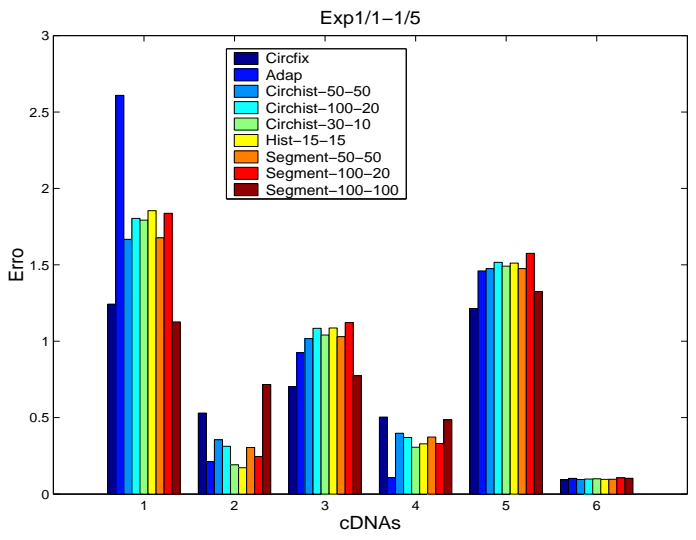

(A)

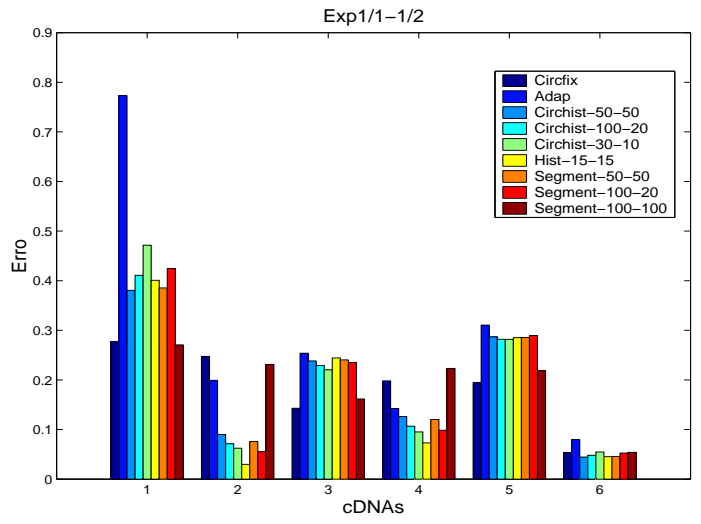

(B)

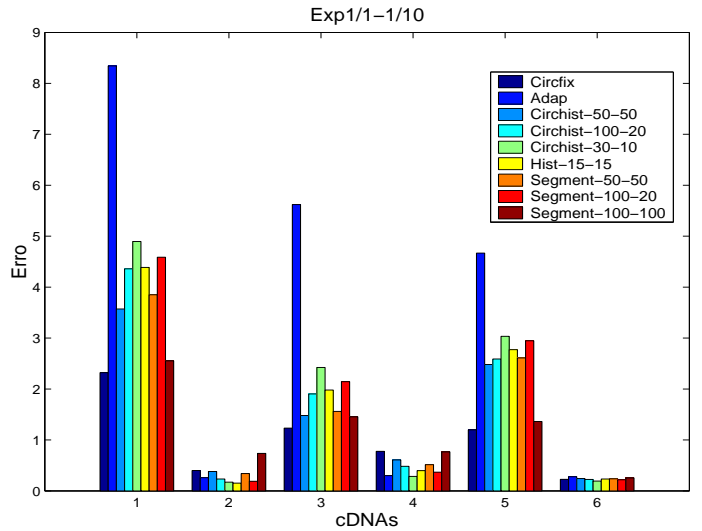

(C)

Figura 6.4: Erros cometidos nos experimentos exp1/1-5/1, exp1/1-2/1 e $\exp 1 / 1-10 / 1$.

Essa figura mostra os erros cometidos pelas diferentes metodologias nos experimentos (A) - exp1/1-5/1, (B) - exp1/1-2/1 e (C) - exp1/1-10/1. Os cDNAs estão indicados no eixo $x$ na seguinte ordem: 1 - LysA, 2 - TrpC, 3 - Gene Q, 4 - ST0280, 5 - Il-6, 6 Irf-1. 
Tabela 6.1: Dados obtidos para o experimento exp1/1 (diluição cinco).

Médias, desvios padrão e erros obtidos para todos os fragmentos da sonda que apresentam diluição cinco no experimento exp1/1. Neste experimento é esperada razão um para todos os cDNAs.

Experimento exp1/1, com diluição cinco

\begin{tabular}{|c|c|c|c|c|c|c|c|c|c|c|c|c|c|c|c|c|c|c|}
\hline \multirow{2}{*}{$\overline{\text { Soft }}$} & \multicolumn{3}{|c|}{$\overline{\text { LysA }}$} & \multicolumn{3}{|c|}{$\overline{\text { TrpC }}$} & \multicolumn{3}{|c|}{$\overline{\text { Gene Q }}$} & \multicolumn{3}{|c|}{ ST0280 } & \multicolumn{3}{|c|}{ I16 } & \multicolumn{3}{|c|}{ Irf1 } \\
\hline & $\mu$ & $\mathbf{E}$ & DP & $\mu$ & $\mathbf{E}$ & DP & $\mu$ & $\mathbf{E}$ & DP & $\mu$ & $\mathbf{E}$ & DP & $\mu$ & $\mathbf{E}$ & DP & $\mu$ & $\mathbf{E}$ & DP \\
\hline Circfix & 1.09 & 0.11 & 0.12 & 1.25 & 0.26 & 0.18 & 0.88 & 0.13 & 0.08 & 1.16 & 0.18 & 0.19 & 1.30 & 0.30 & 0.16 & 1.03 & 0.09 & 0.13 \\
\hline Adap & 1.65 & 0.65 & 0.29 & 2.00 & 1.00 & 0.30 & 0.93 & 0.10 & 0.08 & 1.67 & 0.68 & 0.30 & 1.28 & 0.28 & 0.16 & 1.04 & 0.09 & 0.12 \\
\hline Circhist-50-50 & 1.12 & 0.13 & 0.12 & 1.28 & 0.28 & 0.17 & 0.90 & 0.12 & 0.08 & 1.20 & 0.21 & 0.19 & 1.30 & 0.30 & 0.17 & 1.03 & 0.09 & 0.13 \\
\hline Circhist-100-20 & 1.11 & 0.11 & 0.12 & 1.27 & 0.27 & 0.16 & 0.89 & 0.12 & 0.08 & 1.18 & 0.19 & 0.18 & 1.30 & 0.30 & 0.16 & 1.03 & 0.09 & 0.13 \\
\hline Circhist-30-10 & 1.11 & 0.12 & 0.13 & 1.28 & 0.28 & 0.18 & 0.88 & 0.13 & 0.08 & 1.12 & 0.18 & 0.19 & 1.29 & 0.29 & 0.16 & 1.03 & 0.09 & 0.13 \\
\hline Hist-15-15 & 1.11 & 0.12 & 0.12 & 1.27 & 0.27 & 0.16 & 0.92 & 0.10 & 0.08 & 1.23 & 0.23 & 0.19 & 1.36 & 0.36 & 0.17 & 1.04 & 0.09 & 0.13 \\
\hline Segment-50-50 & 1.12 & 0.12 & 0.12 & 1.28 & 0.28 & 0.16 & 0.89 & 0.12 & 0.09 & 1.19 & 0.20 & 0.20 & 1.30 & 0.30 & 0.17 & 1.03 & 0.09 & 0.13 \\
\hline Segment-100-20 & 1.09 & 0.11 & 0.12 & 1.26 & 0.26 & 0.16 & 0.88 & 0.13 & 0.08 & 1.17 & 0.18 & 0.18 & 1.28 & 0.28 & 0.16 & 1.03 & 0.09 & 0.13 \\
\hline Segment-100-100 & 1.09 & 0.10 & 0.12 & 1.26 & 0.26 & 0.17 & 0.88 & 0.13 & 0.08 & 1.15 & 0.18 & 0.19 & 1.29 & 0.29 & 0.16 & 1.03 & 0.09 & 0.13 \\
\hline
\end{tabular}


Tabela 6.2: Dados obtidos para o experimento exp1/1.

Médias, desvios padrão e erros obtidos para todos os fragmentos com diluição um da sonda no experimento exp1/1. Neste experimento é esperada razão um para todos os cDNAs.

\begin{tabular}{|c|c|c|c|c|c|c|c|c|c|c|c|c|c|c|c|c|c|c|}
\hline \multicolumn{19}{|c|}{ Experimento exp1/1, com diluição um } \\
\hline \multirow[t]{2}{*}{$\overline{\text { Soft }}$} & \multicolumn{3}{|c|}{ LysA } & \multicolumn{3}{|c|}{ TrpC } & \multicolumn{3}{|c|}{ Gene Q } & \multicolumn{3}{|c|}{ ST0280 } & \multicolumn{3}{|c|}{$\overline{I 16}$} & \multicolumn{3}{|c|}{$\overline{\text { Irf1 }}$} \\
\hline & $\mu$ & $\mathbf{E}$ & DP & $\mu$ & $\mathbf{E}$ & $\mathbf{D P}$ & $\mu$ & $\mathbf{E}$ & $\overline{\mathbf{D P}}$ & $\mu$ & $\overline{\mathbf{E}}$ & DP & $\mu$ & $\overline{\mathbf{E}}$ & $\overline{\mathbf{D P}}$ & $\mu$ & $\mathbf{E}$ & $\overline{\mathbf{D P}}$ \\
\hline Circfix & 1.02 & 0.05 & 0.06 & 1.22 & 0.22 & 0.07 & 0.80 & 0.20 & 0.05 & 1.02 & 0.06 & 0.07 & 1.07 & 0.07 & 0.05 & 0.89 & 0.12 & 0.07 \\
\hline Adap & 1.00 & 0.04 & 0.06 & 1.27 & 0.27 & 0.18 & 0.79 & 0.21 & 0.05 & 1.02 & 0.06 & 0.07 & 1.05 & 0.07 & 0.06 & 0.88 & 0.12 & 0.07 \\
\hline Circhist-50-50 & 1.02 & 0.05 & 0.05 & 1.22 & 0.22 & 0.07 & 0.81 & 0.19 & 0.04 & 1.02 & 0.06 & 0.07 & 1.05 & 0.06 & 0.05 & 0.89 & 0.11 & 0.06 \\
\hline Circhist-100-20 & 1.01 & 0.04 & 0.06 & 1.21 & 0.21 & 0.07 & 0.80 & 0.20 & 0.04 & 1.02 & 0.06 & 0.07 & 1.06 & 0.07 & 0.05 & 0.89 & 0.12 & 0.07 \\
\hline Circhist-30-10 & 1.01 & 0.05 & 0.06 & 1.20 & 0.21 & 0.10 & 0.81 & 0.19 & 0.04 & 1.03 & 0.06 & 0.07 & 1.06 & 0.07 & 0.05 & 0.89 & 0.11 & 0.07 \\
\hline Hist-15-15 & 1.02 & 0.04 & 0.06 & 1.22 & 0.22 & 0.08 & 0.81 & 0.19 & 0.04 & 1.02 & 0.06 & 0.06 & 1.04 & 0.05 & 0.05 & 0.89 & 0.12 & 0.06 \\
\hline Segment-50-50 & 1.02 & 0.05 & 0.05 & 1.23 & 0.23 & 0.07 & 0.81 & 0.19 & 0.04 & 1.02 & 0.06 & 0.06 & 1.05 & 0.06 & 0.05 & 0.90 & 0.11 & 0.06 \\
\hline Segment-100-20 & 1.01 & 0.04 & 0.06 & 1.21 & 0.21 & 0.07 & 0.81 & 0.19 & 0.04 & 1.02 & 0.06 & 0.07 & 1.07 & 0.08 & 0.05 & 0.90 & 0.11 & 0.07 \\
\hline Segment-100-100 & 1.01 & 0.05 & 0.06 & 1.21 & 0.21 & 0.07 & 0.81 & 0.19 & 0.04 & 1.02 & 0.06 & 0.07 & 1.07 & 0.08 & 0.05 & 0.90 & 0.11 & 0.07 \\
\hline
\end{tabular}


Tabela 6.3: Dados obtidos para o experimento exp3/1.

Médias, desvios padrão e erros obtidos para todos os fragmentos com diluição um da sonda no experimento exp3/1.

Neste experimento é esperada razão três para todos os cDNAs.

\begin{tabular}{|c|c|c|c|c|c|c|c|c|c|c|c|c|c|c|c|c|c|c|}
\hline \multicolumn{19}{|c|}{ Experimento exp3/1, com diluição um } \\
\hline \multirow[t]{2}{*}{ 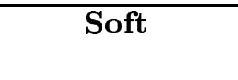 } & \multicolumn{3}{|c|}{ LysA } & \multicolumn{3}{|c|}{ TrpC } & \multicolumn{3}{|c|}{ Gene Q } & \multicolumn{3}{|c|}{ ST0280 } & \multicolumn{3}{|c|}{ I16 } & \multicolumn{3}{|c|}{ Irf1 } \\
\hline & $\mu$ & $\overline{\mathbf{E}}$ & $\mathbf{D P}$ & $\mu$ & $\overline{\mathbf{E}}$ & $\mathbf{D P}$ & $\mu$ & $\mathbf{E}$ & $\overline{\mathbf{D P}}$ & $\mu$ & $\overline{\mathbf{E}}$ & DP & $\mu$ & $\mathbf{E}$ & $\overline{\mathbf{D P}}$ & $\mu$ & $\mathbf{E}$ & DP \\
\hline Circfix & 3.16 & 0.31 & 0.38 & 4.93 & 2.48 & 8.37 & 3.34 & 0.34 & 0.18 & 3.61 & 0.73 & 0.75 & 3.44 & 0.44 & 0.24 & 3.72 & 0.74 & 0.31 \\
\hline Adap & 1.90 & 1.10 & 0.38 & 0.99 & 2.10 & 0.72 & 3.19 & 0.22 & 0.17 & 0.85 & 2.15 & 0.22 & 3.24 & 0.26 & 0.21 & 3.41 & 0.44 & 0.29 \\
\hline Circhist-50-50 & 2.75 & 0.27 & 0.25 & 1.98 & 1.02 & 0.29 & 3.15 & 0.17 & 0.15 & 2.53 & 0.49 & 0.29 & 3.22 & 0.24 & 0.19 & 3.41 & 0.41 & 0.20 \\
\hline Circhist-100-20 & 2.64 & 0.36 & 0.27 & 1.86 & 1.14 & 0.31 & 3.14 & 0.17 & 0.14 & 2.42 & 0.59 & 0.31 & 3.22 & 0.25 & 0.20 & 3.39 & 0.42 & 0.26 \\
\hline Circhist-30-10 & 2.65 & 0.38 & 0.38 & 1.72 & 1.28 & 0.41 & 3.19 & 0.21 & 0.17 & 2.36 & 0.65 & 0.37 & 3.26 & 0.27 & 0.19 & 3.41 & 0.45 & 0.26 \\
\hline Hist-15-15 & 2.64 & 0.37 & 0.27 & 1.47 & 1.53 & 0.22 & 3.12 & 0.15 & 0.13 & 2.15 & 0.85 & 0.26 & 3.19 & 0.22 & 0.19 & 3.36 & 0.36 & 0.19 \\
\hline Segment-50-50 & 2.75 & 0.28 & 0.25 & 1.86 & 1.14 & 0.36 & 3.15 & 0.17 & 0.14 & 2.52 & 0.49 & 0.30 & 3.23 & 0.25 & 0.19 & 3.41 & 0.42 & 0.20 \\
\hline Segment-100-20 & 2.65 & 0.36 & 0.27 & 1.71 & 1.29 & 0.33 & 3.14 & 0.16 & 0.13 & 2.35 & 0.65 & 0.30 & 3.20 & 0.22 & 0.18 & 3.36 & 0.39 & 0.24 \\
\hline Segment-100-100 & 3.23 & 0.37 & 0.47 & 3.41 & 1.35 & 1.97 & 3.32 & 0.32 & 0.18 & 4.44 & 1.62 & 2.91 & 3.44 & 0.44 & 0.23 & 3.71 & 0.73 & 0.31 \\
\hline
\end{tabular}


Tabela 6.4: Dados obtidos para o experimento exp6/1.

Médias, desvios padrão e erros obtidos para todos os fragmentos com diluição um da sonda no experimento exp6/1. Neste experimento é esperada razão seis para todos os cDNAs.

\begin{tabular}{|c|c|c|c|c|c|c|c|c|c|c|c|c|c|c|c|c|c|c|}
\hline \multicolumn{19}{|c|}{ Experimento exp6/1, com diluição um } \\
\hline \multirow[t]{2}{*}{$\overline{\text { Soft }}$} & \multicolumn{3}{|c|}{$\overline{\text { LysA }}$} & \multicolumn{3}{|c|}{ TrpC } & \multicolumn{3}{|c|}{ Gene Q } & \multicolumn{3}{|c|}{ ST0280 } & \multicolumn{3}{|c|}{ I16 } & \multicolumn{3}{|c|}{ Irf1 } \\
\hline & $\mu$ & $\mathbf{E}$ & DP & $\mu$ & $\mathbf{E}$ & $\overline{\mathbf{D P}}$ & $\mu$ & $\overline{\mathbf{E}}$ & $\overline{\mathbf{D P}}$ & $\mu$ & $\overline{\mathbf{E}}$ & DP & $\mu$ & $\overline{\mathbf{E}}$ & $\overline{\mathbf{D P}}$ & $\mu$ & $\overline{\mathbf{E}}$ & $\overline{\mathbf{D P}}$ \\
\hline Circfix & 3.33 & 2.67 & 0.57 & 2.78 & 3.46 & 1.90 & 3.11 & 2.89 & 0.27 & 4.08 & 4.41 & 8.74 & 3.57 & 2.43 & 0.40 & 3.88 & 2.12 & 0.58 \\
\hline Adap & 2.38 & 3.62 & 0.61 & 0.62 & 5.38 & 0.24 & 4.93 & 1.07 & 0.38 & 0.69 & 5.31 & 0.29 & 5.59 & 0.56 & 0.52 & 4.65 & 1.37 & 0.64 \\
\hline Circhist-50-50 & 4.75 & 1.25 & 0.59 & 2.46 & 3.54 & 0.85 & 4.90 & 1.10 & 0.36 & 2.97 & 3.03 & 0.65 & 5.56 & 0.56 & 0.52 & 5.67 & 0.57 & 0.61 \\
\hline Circhist-100-20 & 4.49 & 1.51 & 0.66 & 2.22 & 3.78 & 0.82 & 4.90 & 1.10 & 0.36 & 2.81 & 3.19 & 0.63 & 5.61 & 0.54 & 0.51 & 5.62 & 0.63 & 0.68 \\
\hline Circhist-30-10 & 4.49 & 1.51 & 0.74 & 1.80 & 4.20 & 0.52 & 4.94 & 1.06 & 0.38 & 2.47 & 3.53 & 0.66 & 5.60 & 0.55 & 0.51 & 5.56 & 0.69 & 0.71 \\
\hline Hist-15-15 & 4.52 & 1.48 & 0.59 & 1.59 & 4.41 & 0.29 & 4.85 & 1.15 & 0.36 & 2.42 & 3.58 & 0.49 & 5.51 & 0.60 & 0.52 & 5.49 & 0.67 & 0.64 \\
\hline Segment-50-50 & 4.74 & 1.26 & 0.60 & 2.26 & 3.74 & 0.71 & 4.92 & 1.08 & 0.37 & 2.89 & 3.11 & 0.62 & 5.59 & 0.56 & 0.52 & 5.68 & 0.59 & 0.63 \\
\hline Segment-100-20 & 4.47 & 1.53 & 0.62 & 1.92 & 4.08 & 0.52 & 4.90 & 1.10 & 0.36 & 2.57 & 3.43 & 0.56 & 5.54 & 0.58 & 0.51 & 5.53 & 0.68 & 0.69 \\
\hline Segment-100-100 & 5.98 & 0.82 & 1.09 & 4.11 & 3.11 & 2.94 & 5.37 & 0.64 & 0.42 & 5.20 & 2.57 & 3.09 & 6.14 & 0.51 & 0.66 & 6.63 & 0.87 & 0.95 \\
\hline
\end{tabular}


Tabela 6.5: Dados obtidos para o experimento exp1/1-5/1.

Médias, desvios padrão e erros obtidos para todos os fragmentos com diluição um da sonda no experimento exp1/1-5/1.

Neste experimento é esperada razão um para os cDNAs de TrpC, ST0280 e Irf-1 e razão cinco para os demais.

\begin{tabular}{|c|c|c|c|c|c|c|c|c|c|c|c|c|c|c|c|c|c|c|}
\hline \multicolumn{19}{|c|}{ Experimento exp1/1-5/1, com diluição um } \\
\hline \multirow[t]{2}{*}{ 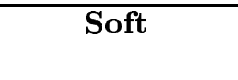 } & \multicolumn{3}{|c|}{ LysA } & \multicolumn{3}{|c|}{ TrpC } & \multicolumn{3}{|c|}{ Gene Q } & \multicolumn{3}{|c|}{ ST0280 } & \multicolumn{3}{|c|}{ I16 } & \multicolumn{3}{|c|}{ Irf1 } \\
\hline & $\mu$ & $\overline{\mathbf{E}}$ & $\mathbf{D P}$ & $\mu$ & $\mathbf{E}$ & $\mathbf{D P}$ & $\mu$ & $\mathbf{E}$ & $\overline{\mathbf{D P}}$ & $\mu$ & $\overline{\mathbf{E}}$ & DP & $\mu$ & $\mathbf{E}$ & $\overline{\mathbf{D P}}$ & $\mu$ & $\overline{\mathbf{E}}$ & DP \\
\hline Circfix & 3.76 & 1.24 & 0.37 & 1.53 & 0.53 & 0.23 & 4.30 & 0.70 & 0.21 & 1.50 & 0.50 & 0.17 & 3.80 & 1.21 & 0.32 & 0.91 & 0.09 & 0.04 \\
\hline Adap & 2.39 & 2.61 & 0.36 & 0.79 & 0.21 & 0.12 & 4.09 & 0.93 & 0.25 & 1.08 & 0.11 & 0.11 & 3.54 & 1.46 & 0.18 & 0.90 & 0.10 & 0.03 \\
\hline Circhist-50-50 & 3.33 & 1.67 & 0.26 & 1.36 & 0.36 & 0.11 & 3.98 & 1.02 & 0.15 & 1.40 & 0.40 & 0.09 & 3.52 & 1.48 & $\overline{0.17}$ & 0.90 & 0.10 & 0.03 \\
\hline Circhist-100-20 & 3.20 & 1.80 & 0.25 & 1.31 & 0.31 & 0.11 & 3.92 & 1.08 & 0.13 & 1.37 & 0.37 & 0.09 & 3.48 & 1.52 & 0.16 & 0.90 & 0.10 & 0.03 \\
\hline Circhist-30-10 & 3.21 & 1.79 & 0.28 & 1.18 & 0.19 & 0.17 & 3.96 & 1.04 & 0.19 & 1.31 & 0.31 & 0.11 & 3.51 & 1.49 & $\overline{0.17}$ & 0.90 & 0.10 & 0.03 \\
\hline Hist-15-15 & 3.15 & 1.85 & 0.23 & 1.17 & 0.17 & 0.12 & 3.91 & 1.09 & 0.14 & 1.33 & 0.33 & 0.11 & 3.49 & 1.51 & 0.16 & 0.90 & 0.10 & 0.03 \\
\hline Segment-50-50 & 3.32 & 1.68 & 0.24 & 1.30 & 0.30 & 0.12 & 3.97 & 1.03 & 0.14 & 1.37 & 0.37 & 0.10 & 3.52 & 1.48 & 0.17 & 0.90 & 0.10 & 0.03 \\
\hline Segment-100-20 & 3.16 & 1.84 & 0.26 & 1.24 & 0.25 & 0.14 & 3.88 & 1.12 & 0.16 & 1.33 & 0.33 & 0.09 & 3.42 & 1.58 & 0.15 & 0.89 & 0.11 & 0.03 \\
\hline Segment-100-100 & 3.88 & 1.13 & 0.41 & 1.70 & 0.72 & 0.87 & 4.24 & 0.77 & 0.28 & 1.49 & 0.49 & 0.17 & 3.67 & 1.33 & 0.18 & 0.90 & 0.10 & 0.03 \\
\hline
\end{tabular}


Tabela 6.6: Dados obtidos para o experimento exp1/1-2/1.

Médias, desvios padrão e erros obtidos para todos os fragmentos com diluição um da sonda no experimento exp1/1-2/1.

Neste experimento é esperada razão um para os cDNAs de TrpC, ST0280 e Irf-1 e razão dois para os demais.

\begin{tabular}{|c|c|c|c|c|c|c|c|c|c|c|c|c|c|c|c|c|c|c|}
\hline \multicolumn{19}{|c|}{ Experimento exp1/1-2/1, com diluição um } \\
\hline \multirow[t]{2}{*}{$\overline{\text { Soft }}$} & \multicolumn{3}{|c|}{$\overline{\overline{\text { LysA }}}$} & \multicolumn{3}{|c|}{ TrpC } & \multicolumn{3}{|c|}{ Gene Q } & \multicolumn{3}{|c|}{ ST0280 } & \multicolumn{3}{|c|}{ I16 } & \multicolumn{3}{|c|}{ Irf1 } \\
\hline & $\mu$ & $\overline{\mathbf{E}}$ & $\overline{\mathbf{D P}}$ & $\bar{\mu}$ & $\overline{\mathbf{E}}$ & $\overline{\mathbf{D P}}$ & $\mu$ & $\mathbf{E}$ & $\overline{\mathbf{D P}}$ & $\mu$ & $\overline{\mathbf{E}}$ & $\overline{\mathbf{D P}}$ & $\mu$ & $\overline{\mathbf{E}}$ & $\overline{\mathbf{D P}}$ & $\mu$ & $\overline{\mathbf{E}}$ & $\overline{\mathbf{D P}}$ \\
\hline Circfix & 1.72 & 0.28 & 0.17 & 1.22 & 0.25 & 0.37 & 1.87 & 0.14 & 0.09 & 1.20 & 0.20 & 0.08 & 1.81 & 0.19 & 0.09 & 0.98 & 0.05 & 0.07 \\
\hline Adap & 1.23 & 0.77 & 0.17 & 0.87 & 0.20 & 0.21 & 1.75 & 0.25 & 0.08 & 0.97 & 0.14 & 0.21 & 1.69 & 0.31 & 0.09 & 0.95 & 0.08 & 0.09 \\
\hline Circhist-50-50 & 1.62 & 0.38 & 0.10 & 1.08 & 0.09 & 0.06 & 1.76 & 0.24 & 0.07 & 1.13 & 0.13 & 0.05 & 1.71 & 0.29 & 0.08 & 0.97 & 0.04 & 0.05 \\
\hline Circhist-100-20 & 1.59 & 0.41 & 0.10 & 1.06 & 0.07 & 0.06 & 1.77 & 0.23 & 0.07 & 1.11 & 0.11 & 0.05 & 1.72 & 0.28 & 0.08 & 0.97 & 0.05 & 0.05 \\
\hline Circhist-30-10 & 1.53 & 0.47 & 0.18 & 1.01 & 0.06 & 0.08 & 1.78 & 0.22 & 0.07 & 1.08 & 0.10 & 0.08 & 1.72 & 0.28 & 0.09 & 0.97 & 0.05 & 0.06 \\
\hline Hist-15-15 & 1.60 & 0.40 & 0.09 & 1.01 & 0.03 & 0.04 & 1.76 & 0.24 & 0.07 & 1.07 & 0.07 & 0.04 & 1.71 & 0.29 & 0.08 & 0.97 & 0.05 & 0.05 \\
\hline Segment-50-50 & 1.61 & 0.39 & 0.10 & 1.07 & 0.08 & 0.06 & 1.76 & 0.24 & 0.07 & 1.12 & 0.12 & 0.05 & 1.71 & 0.29 & 0.08 & 0.97 & 0.05 & 0.05 \\
\hline Segment-100-20 & 1.58 & 0.42 & 0.12 & 1.04 & 0.06 & 0.06 & 1.76 & 0.24 & 0.06 & 1.10 & 0.10 & 0.05 & 1.71 & 0.29 & 0.08 & 0.97 & 0.05 & 0.06 \\
\hline Segment-100-100 & 1.79 & 0.27 & 0.22 & 1.22 & 0.23 & 0.24 & 1.84 & 0.16 & 0.07 & 1.22 & 0.22 & 0.12 & 1.78 & 0.22 & 0.10 & 0.98 & 0.05 & 0.08 \\
\hline
\end{tabular}


Tabela 6.7: Dados obtidos para o experimento exp1/1-10/1.

Médias, desvios padrão e erros obtidos para todos os fragmentos com diluição um da sonda no experimento exp1/1-10/1.

Neste experimento é esperada razão um para os cDNAs de TrpC, ST0280 e Irf-1 e razão dez para os demais.

\begin{tabular}{|c|c|c|c|c|c|c|c|c|c|c|c|c|c|c|c|c|c|c|}
\hline \multicolumn{19}{|c|}{ Experimento exp1/1-10/1, com diluição um } \\
\hline \multirow[t]{2}{*}{$\overline{\text { Soft }}$} & \multicolumn{3}{|c|}{ LysA } & \multicolumn{3}{|c|}{ TrpC } & \multicolumn{3}{|c|}{ Gene Q } & \multicolumn{3}{|c|}{ ST0280 } & \multicolumn{3}{|c|}{$\overline{\mathbf{I 1 6}}$} & \multicolumn{3}{|c|}{ Irf1 } \\
\hline & $\mu$ & $\mathbf{E}$ & $\overline{D P}$ & $\mu$ & $\mathbf{E}$ & DP & $\mu$ & $\mathbf{E}$ & DP & $\mu$ & $\mathbf{E}$ & DP & $\mu$ & $\mathbf{E}$ & DP & $\mu$ & $\mathbf{E}$ & $\overline{\mathbf{D P}}$ \\
\hline Circfix & 7.82 & 2.32 & 1.83 & 1.39 & 0.40 & 0.31 & 10.55 & 1.23 & 1.52 & 1.78 & 0.78 & 0.34 & 8.87 & 1.20 & 1.17 & 1.23 & 0.23 & 0.08 \\
\hline Adap & 1.66 & 8.34 & 0.47 & 0.76 & 0.26 & 0.17 & 4.38 & 5.62 & 1.00 & 0.70 & 0.30 & 0.17 & 5.33 & 4.67 & 0.80 & 1.28 & 0.28 & 0.10 \\
\hline Circhist-50-50 & 6.43 & 3.57 & 0.81 & 1.38 & 0.38 & 0.15 & 8.52 & 1.48 & 0.70 & 1.61 & 0.61 & 0.14 & 7.52 & 2.48 & 0.41 & 1.24 & 0.24 & 0.05 \\
\hline Circhist-100-20 & 5.64 & 4.36 & 0.98 & 1.23 & 0.23 & 0.16 & 8.10 & 1.90 & 0.86 & 1.48 & 0.48 & 0.18 & 7.41 & 2.59 & 0.61 & 1.23 & 0.22 & 0.07 \\
\hline Circhist-30-10 & 5.10 & 4.90 & 1.18 & 1.07 & 0.17 & 0.21 & 7.58 & 2.42 & 1.21 & 1.27 & 0.29 & 0.25 & 6.97 & 3.03 & 0.94 & 1.19 & 0.19 & 0.09 \\
\hline Hist-15-15 & 5.61 & 4.39 & 0.74 & 1.13 & 0.15 & 0.13 & 8.02 & 1.98 & 0.73 & 1.40 & 0.40 & 0.12 & 7.23 & 2.77 & 0.48 & 1.23 & 0.23 & 0.06 \\
\hline Segment-50-50 & 6.15 & 3.85 & 0.87 & 1.34 & 0.34 & 0.14 & 8.44 & 1.56 & 0.70 & 1.51 & 0.51 & 0.17 & 7.39 & 2.61 & 0.46 & 1.24 & 0.24 & 0.06 \\
\hline Segment-100-20 & 5.41 & 4.59 & 1.01 & 1.18 & 0.19 & 0.15 & 7.86 & 2.14 & 0.86 & 1.36 & 0.37 & 0.22 & 7.05 & 2.95 & 0.74 & 1.22 & 0.22 & 0.07 \\
\hline Segment-100-100 & 8.68 & 2.55 & 3.36 & 1.74 & 0.74 & 0.72 & 10.94 & 1.45 & 2.29 & 1.77 & 0.77 & 0.83 & 8.66 & 1.36 & 0.91 & 1.26 & 0.26 & 0.07 \\
\hline
\end{tabular}




\section{Capítulo 7}

\section{Conclusão}

Esse trabalho foi motivado pela dificuldade de alguns pesquisadores no uso das soluções de segmentação de imagens disponíveis. Tais soluções, em geral, requerem uma demorada manipulação das imagens para que se obtenha uma segmentação de qualidade, já que a grade é colocada manualmente ou a segmentação automática não funciona bem. A estratégia de solução do problema se baseia na análise dos perfis da imagem: o sinal é identificado pelos valores do perfil muito mais altos que os do background.

A metodologia desenvolvida segmenta automaticamente o sinal de imagens de cDNA sem a necessidade de intensa manipulação normalmente requerida ao se usarem os programas comerciais disponíveis no mercado, além de serem reprodutíveis. Uma lâmina analisada com os mesmos parâmetros retorna resultados idênticos. Os resultados obtidos são equivalentes aos de outros programas em relação ao erro observado.

Uma das deficiências da solução proposta é a necessidade, em algumas imagens, de uma correção de rotação, ou seja, os spots devem estar alinhados com as bordas da imagem. Além disso, o passo de correção do gradeamento dos spots não aproveita a informação do perfil, o que pode ocasionar erros, especialmente em imagens onde cada bloco possui muitas fileiras de spots.

Entre os passos futuros da pesquisa estão: a correção automática da rotação da imagem, identificação automática de spots ruins, testar estatisticamente se os experimentos controlados representam realmente experimentos reais e fazer a escolha automática do melhor método de 
estimação da expressão gênica para cada spot.

Como se trata de uma medida física, com erro experimental associado, gostaríamos de associar barras de erro a cada medida de expressão gênica.

O software de segmentação deverá se tornar parte de um sistema completo de análise de microarray, com módulos de normalização, análise estatística e de agrupamentos, e integrado a um bancos de dados para armazenar informações sobre o experimento, seus genes e resultados. 


\section{Apêndice A}

\section{Publicações associadas a esta dissertação}

- Roberto Hirata Jr., Junior Barrera, Ronaldo F. Hashimoto, Daniel O. Dantas, and Gustavo Esteves. Segmentation of microarray images by mathematical morphology. Real-Time Imaging, 8(6):491-505, December 2002.

- http://www.vision.ime.usp.br/ ddantas/slides/icobicobi2003/icobicobi2003.ppt.

Daniel Oliveira Dantas, Junior Barrera, Gustavo Henrique Esteves and Roberto Hirata Junior. Poster 10.33: A software for automatically measuring gene expression from microarray images. $1^{\text {st }}$ International Conference on Bioinformatics and Computational Biology.

- Junior Barrera, R. M. Cesar Jr., Daniel O. Dantas, and D. C. Martins Jr. From microarray images to biological knowledge. II Brazilian Symposium of Mathematical and Computational Biology, 2002.

- Roberto Hirata Jr., Junior Barrera, Ronaldo F. Hashimoto, and Daniel O. Dantas. Microarray gridding by mathematical morphology. In: Proc. SIBGRAPI, Florianópolis. IEEE, pages 112-119, 2001. 


\section{Apêndice B}

\section{Normalização}

\section{B.1 Introdução}

A tecnologia de microarray visa medir as diferenças biológicas entre a expressão de RNA de duas amostras. No entanto, tais diferenças podem ser causadas por ruído ou outros fatores não biológicos e isso deve ser ajustado. Tais diferenças são facilmente observadas quando duas amostras idênticas de mRNA são marcadas com corantes diferentes e hibridizadas na mesma lâmina. A intensidade no canal vermelho tende a ser menor que a do canal verde. Tal diferença também varia entre spots mais e menos intensos [33].

Isso se deve a diferentes características físicas e químicas dos corantes fluorescentes (meia vida, eficiência da incorporação, emissão de fluorescência), propriedades ou configurações do scanner. Outra fonte de ruído vem da posição do spot na lâmina, causado por diferenças entre o tamanho das agulhas ou por uma hibridização não uniforme. Entre lâminas diferentes, condições diferentes na hora do experimento também devem causar variações [34, 35].

Para que se obtenha uma medida de melhor qualidade, isso deve ser corrigido. As técnicas de normalização são usadas para isso, e aqui descreveremos algumas das mais utilizadas.

Usaremos a letra $R$ para representar os valores dos spots no canal vermelho, e $G$ para os valores do canal verde. Uma forma bastante conveniente de se representar os valores de $R$ e $G$ é o chamado $M A$-plot [33], que é um gráfico de dispersão onde a abscissa é dada por $A=\frac{1}{2} \log _{2} R G$ 
e a ordenada por $M=\log _{2} R / G$.

\section{B.2 Normalização intralâmina}

Esse tipo de normalização é feita separadamente para cada lâmina, utilizando apenas as intensidades dos spots nos dois canais.

No caso de experimentos de membrana, onde cada lâmina possui um único canal, a normalização é feita utilizando-se as intensidades dos spots de duas lâminas diferentes.

\section{B.2.1 Normalização global}

Tais métodos assumem que existe um fator constante que relaciona as intensidades nos dois canais [27], ou seja, $R=k G$. Para encontrar o valor de $k$, pode-se assumir que a média e/ou média aparada (média após desprezar percentis extremos) e/ou a mediana das razões das intensidades deve ser igual a um. Este é o método mais simples e também o mais utilizado.

\section{B.2.2 Normalização por genes de housekeeping}

É um tipo de normalização global que usa genes dos quais se espera que a expressão nos dois canais sejam as mesmas. Assumindo que a expressão de genes igualmente expressos deva ser constante independente da intensidade, tais genes podem ser usados para se estimar tal constante.

Yang et al. [36] usa genes dos quais se espera, por experiências anteriores, que tenham a mesma expressão em suas amostras teste e referência.

\section{B.2.3 Normalização segundo a intensidade}

Em muitos casos, a variação causada pelos corantes parece depender da intensidade dos spots. Nesses casos, é preferível usar um método de normalização que dependa da intensidade. Uma forma de se fazê-lo é usando o método de regressão conhecido como lowess (Robust Locally 
Weighted Regression) [36, 37].

Tal função é um alisador de gráficos de dispersão que faz um ajuste diferente para cada ponto do gráfico segundo os pontos que o circundam. A fração dos pontos considerados depende do parâmetro $f$, que é usado tipicamente entre $20 \%$ e $40 \%$. Seja $c(A)$ o valor da curva para cada valor de $A$. Os valores de $M$ são normalizados fazendo $M \rightarrow M-c(A)$.

\section{B.3 Normalização por swap}

Se supusermos que a hibridização segue um certo modelo matemático, e fizermos o experimento em duplicata, mas trocando os corantes das amostras, a normalização por swap anula os efeitos causados pelas diferentes características físicas dos corantes [36].

Sejam $R / k G$ as expressões relativas normalizadas dos genes da primeira lâmina, e $R^{\prime} / k^{\prime} G^{\prime}$ as expressões da segunda lâmina. Os valores de $k$ e $k^{\prime}$ são funcões de normalização para as duas lâminas que poderiam ser obtidos por algum método intralâmina já descrito. A expressão relativa, denotada por $x$, dos genes da primeira lâmina deve ser, igual ao inverso da segunda lâmina:

$$
\frac{R}{k G} \approx \frac{k^{\prime} G^{\prime}}{R^{\prime}}
$$

Se $k \approx k^{\prime}$ então

$$
\sqrt{\frac{R}{k G} \frac{k^{\prime} G^{\prime}}{R^{\prime}}} \approx \sqrt{\frac{R G^{\prime}}{G R^{\prime}}}
$$

nos dá a expressão relativa dos genes normalizada sem que tenhamos que estimar o valor de $k$. 


\section{Referências Bibliográficas}

[1] D. J. Duggan, M. Bittner, Y. Chen, P. Meltzer, and J. M. Trent. Expression Profiling Using cDNA Microarrays. Nature (Genetics Supplement), 21:10-14, January 1999.

[2] Yee Hwa Yang, Michael J. Buckley, Sandrine Dudoit, and Terence P. Speed. Comparison of methods for image analysis on cdna microarray data. Technical report, Department of Statistics, University of California at Berkeley.

[3] Aimée M. Dudley, John Aach, Martin A. Steffen, and George M. Church. Measuring absolute expression with microarrays with a calibrated reference sample and an extended signal intensity range. PNAS, 99(11):7554-7559, May 2002.

[4] Affymetrix. Affymetrix® GeneChipß $\mathrm{B}$ Technology Overview. page http://www .affymetrix.com/technology/.

[5] Robert J. Lipshutz, Stephen P. A. Fodor, Thomas R. Gingeras, and David J. Lockhart. High density synthetic onigonucleotide arrays. Supplement to Nature Genetics, 21:20-24, January 1999.

[6] The chipping forecast. Supplement to Nature Genetics, 21, January 1999.

[7] Carl S. Brown, Paul C. Goodwin, and Peter K. Sorger. Image metrics in the statistical analysis of dna microarray data. PNAS, 98(16):8944-8949, July 2001.

[8] Jesús Angulo and Jean Serra. Automatic analysis of DNA microarray images using mathematical morphology. Bioinformatics, 19(5):553-562, 2003.

[9] A. Brazma and J. Vilo. Gene expression data analysis. FEBS Letters, 480(1):17-24, August 2000 .

[10] P. D'haeseleer. Reconstructing Gene Networks from Large Scale Gene Expression Data. $\mathrm{PhD}$ thesis, The University of New Mexico, 2000.

[11] Zbynek Bozdech, Jingchun Zhu, Brian Pulliam, Marcin Joachimiak, Fred Cohen, and Joseph DeRisi. Expression profiling the schizont and trophozoite stages of plasmodium falciparum with a long oligonucleotide microarray. Genome Biology, 4(2):http://derisilab.ucsf .edu/falciparum/, 2003.

[12] Almut Schulze and Julian Downward. Navigating gene expression using microarrays - a technology review. Nature Cell Biology, 3:E190-E195, August 2001. 
[13] François Bertucci, Karine Bernard, Béatrice Loriod, Yi-Chung Chang, Samuel Granjeaud, Daniel Birnbaum, Catherine Nguyen, Konan Peck, and Bertrand R. Jordan. Sensitivity issues in dna array-based expression measurements and performance of nylon microarrays for small samples. Human Molecular Genetics, 8(9):1715-1722, 1999.

[14] Xiangqin Cui, M. Kathleen Kerr, and Gary A. Churchill. Data transformations for cDNA microarray data. (in press).

[15] G. J. F. Banon and J. Barrera. Bases da Morfologia Matemática para Análise de Imagens Binárias. IX Escola de Computação, Pernambuco, Julho 1994.

[16] Gerald Jean Francis Banon. Formal introduction to digital image processing. Deposited in the URLib collection., 2000. Second edition. This material is used as class notes for an INPE posgraduate course. This work has been supported by CNPq under contract 300966/90-3.

[17] J. Barrera, G. J. F. Banon, R. A. Lotufo, and R. Hirata Jr. MMach: a Mathematical Morphology Toolbox for the Khoros System. Electronic Imaging, 7(1):174-210, 1998.

[18] F. Meyer and S. Beucher. Morphological Segmentation. Journal of Visual Communication and Image Representation, 1(1):21-46, September 1990.

[19] R. Hirata Jr. Segmentação de Imagens por Morfologia Matemática. Master's thesis, Instituto de Matemática e Estatística - USP, março 1997.

[20] S. Beucher. Watersheds of Functions and Picture Segmentation. In ICASSP 82, Proc. IEEE Intern. Conf. on Acoustics, Speech and Signal Processing, pages 1928-1931, Paris, May 1982.

[21] P. Soille and L. Vincent. Determining Watersheds in Digital Pictures via Flooding Simulations. In Visual Communications and Image Processing, pages 240-250. SPIE, 1990. volume 1360 .

[22] L. Vincent and P. Soille. Watersheds in Digital Spaces: An Efficient Algorithm Based on Immersion Simulations. IEEE Transactions on Pattern Analysis and Machine Intelligence, 13(6):583-598, June 1991.

[23] D. Rocke and B. Durbin. A model for measurement error for gene expression arrays. $J$ Comput Biol, 8(6):557-569, 2001.

[24] QuantArray Operating Manual Version 3.0. Packard Bioscience, January 2001.

[25] Michael Eisen. ScanAlyze User Manual. Stanford University, 1999.

[26] M. J. Buckley. The spot user's guide. CSIRO Mathematical and Information Sciences, page http://www.cmis.csiro.au/IAP/Spot/spotmanual.htm, August 2000.

[27] Yidong Chen, Edward R. Dougherty, and Michael L. Bittner. Ratio-Based Decisions and the Quantitative Analysis of cDNA Microarray Images. Biomedical Optics, 2(4):364-374, October 1997. 
[28] Ajay N. Jain, Taku A. Tokuyasu, Antoine N. Snijders, Richard Segraves, Donna G. Albertson, and Daniel Pinkel. Fully automatic quantification of microarray image data. Genome Research, 12(2):325-332, February 2002.

[29] Yidong Chen, Edward R. Dougherty, Michael L. Bittner, Paul Meltzer, and Jeffrey M. Trent. Computational and Statistical Approaches to Genomics, chapter 1 (Microarray Image Analysis and Gene Expression Ratio Statistics). Kluer Academic Publishers, 2002.

[30] David Edwards. Non-linear normalization and background correction in one-channel cDNA microarray studies. Bioinformatics, 19(7):825-833, 2003.

[31] Junior Barrera, Roberto Marcondes Cesar Junior, João Eduardo Ferreira, and Marco Dimas Gubitoso. An environment for knowledge discovery in biology. Computers in Medicine, (in press).

[32] Gustavo Henrique Esteves. Validação de procedimentos para medida de expressão gênica a partir de imagens de cDNA microarray. Master's thesis, Instituto Ludwig de Pesquisa contra o Câncer, Dezembro 2002.

[33] Sandrine Dudoit, Yee Hwa Yang, Matthew J. Callow, and Terence P. Speed. Statistical methods for identifying differentially expressed genes in replicated cDNA microarray experiments. Technical Report 578, Stanford University, August 2000.

[34] Wolfgang Huber, Anja von Heydebreck, and Martin Vingron. Handbook of Statistical Genetics, chapter Analysis of microarray gene expression data. Wiley, second edition, 2003.

[35] Gordon K. Smyth, Yee Hwa Yang, and Terry Speed. Statistical issues in cDNA microarray data analysis.

[36] Yee Hwa Yang, Sandrine Dudoit, Percy Luu, and Terence P. Speed. Normalization for cDNA microarray data. Technical Report 589, January 2001.

[37] Yee Hwa Yang, Sandrine Dudoit, Percy Luu, David M. Lin, Vivian Peng, John Ngai, and Terence P. Speed. Normalization for cDNA microarray data: a robust composite method adressing single and multiple slide systematic variation. Nucleic Acids Research, 30(4), 2002 . 


\section{Índice Remissivo}

abertura, 21, 23, 26, 33, 34, 50

Arrayvision, 17

controle negativo, 2, 45, 47, 49

corante, $1,2,11,16,87-89$

corante fluorescente, 1, 10, 87

cromossomo, 7

dilatação, 20

distância city-block, 22, 59

erosão, 20

fechamento, 21, 23

fluorcromo, 15

gradiente morfológico, 21, 34

hibridização, 10

não específica, 2, 16, 50, 51

MA-plot, 87

MATLAB, 54, 67

modelo, 43

normalização, 87

global, 88

intralâmina, 88

por genes de housekeeping, 88

por swap, 69, 89

segundo a intensidade, 88

nucleotídeo, 7,8

oligonucleotídeo, 35

perfil, 4, 22-27, 33, 62

probe, $2,15,49,51$

QuantArray, 17, 47, 48
ScanAlyze, 16, 47, 48, 64

SDC Morphology Toolbox, 54

sinal fluorescente, 10, 15

Spotfinder, 17

target, $2,15,49-51$

tradução, 8

transcrição, 8

watershed, 4, 22, 34, 35, 49 

Impresso na Gráfica do IME-USP 4 de Agosto de 2004 